\title{
ASSESSMENT OF THE THERMAL PERFORMANCE OF DATA CENTER; A CASE STUDY IN EARTH RANGERS CENTRE
}

\author{
by \\ Ladan Vahidi-Arbabi

\begin{abstract}
A Major Research Project (MRP)
presented to Ryerson University
\end{abstract} \\ in partial fulfillment \\ of the requirements for the degree of \\ Master of Building Science \\ in the program of \\ Building Science
}

B.Arch. Architectural Science, Azad University of Iran, Jan 2012

Toronto, Ontario, Canada, 2019

(C) Ladan Vahidi-Arbabi, 2019 


\section{Author's Declaration}

I hereby declare that I am the sole author of this MRP. This is a true copy of the MRP, including any required final revisions.

I authorize Ryerson University to lend this MRP to other institutions or individuals for the purpose of scholarly research.

I further authorize Ryerson University to reproduce this MRP by photocopying or by other means, in total or in part, at the request of other institutions or individuals for the purpose of scholarly research.

I understand that my MRP may be made electronically available to the public. 


\section{Abstract}

Assessment of The Thermal Performance of Data Center; A Case Study in Earth Rangers Centre

Master of Building Science (MBSc)

Ladan Vahidi-Arbabi

Building Science, Ryerson University, 2019

Thermal performance of complex buildings like data centers is not easy to evaluate.

Experimental Investigation of the effects of energy conservation methods or any alteration that might occur in hundreds of variables in data centres would cost stakeholders time and money. And they might find worthless at times. Building energy model is a well-established field of science with an insufficient number of applications in data centers. This study presents methods of developing a data center model based on an actual case study. Moreover, it identifies effective calibrating strategies to increase the model performance accuracy relative to a recorded dataset. A reliable energy model can assist data center operators and researchers in different ways. As a result, calibrated energy model proved Earth Rangers' data center can be independent of a heat pump or chiller use for most of the year, while ground heat exchangers deliver excessive heat to the ground as the heat sink. 


\section{Acknowledgements}

I would like to thank my professor and research advisor Dr. Zaiyi Liao, for supporting and encouraging my interest, and for providing direction and reassurance throughout my MRP. Also, I would like to express my gratitude to Gavin Yeung for his valuable guidance and support of this research. For giving me the opportunity to have access to Earth Rangers' dataset and providing invaluable advice throughout this research. His dynamism, vision, sincerity and motivation have deeply inspired me. It was a great honour and privilege to work under his direction. I would also like to thank him for his friendship and empathy. 


\section{Contents}

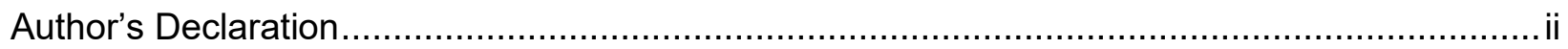

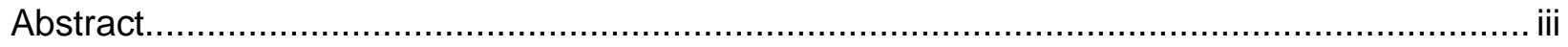

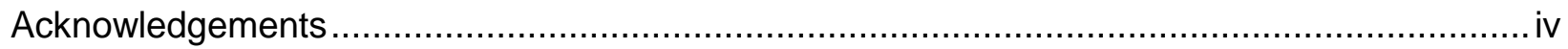

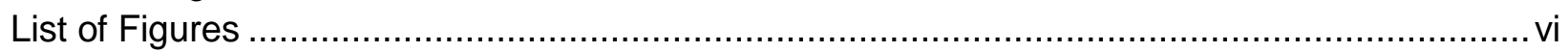

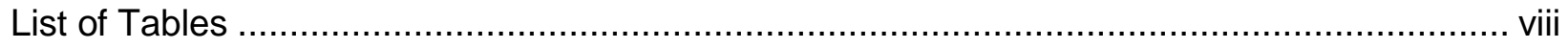

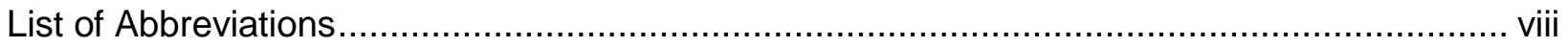

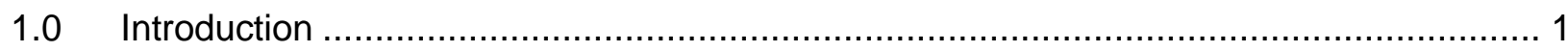

2.0 Literature Review ....................................................................................... 3

2.1 Components and Configuration of Data Centers................................................. 3

2.2 Data Center's Energy Consumption ..................................................................... 7

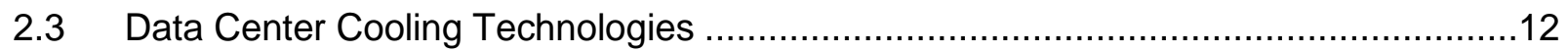

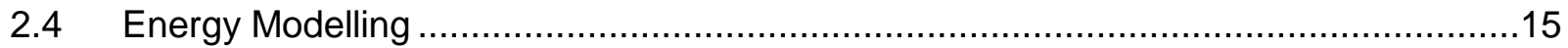

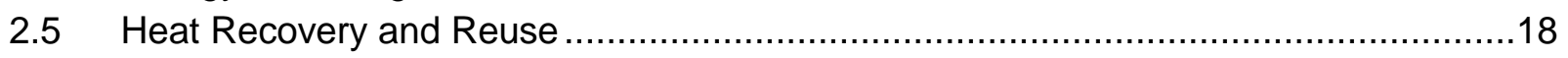

2.5.1 Heat Quality Matters! ............................................................................

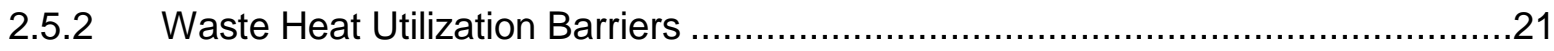

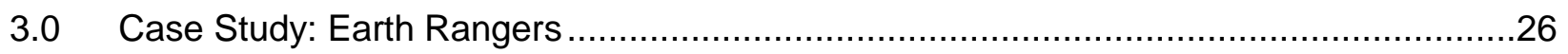

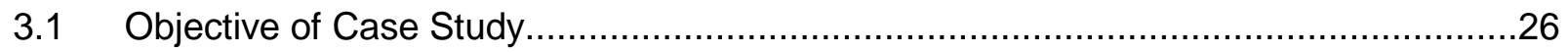

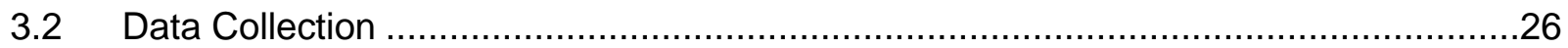

3.3 About ERC .

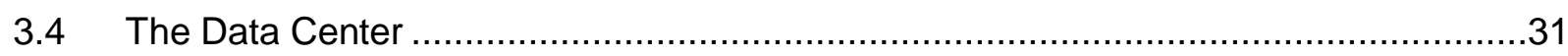

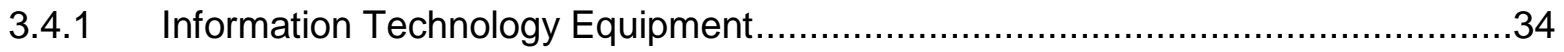

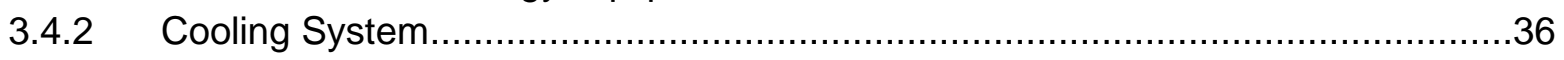

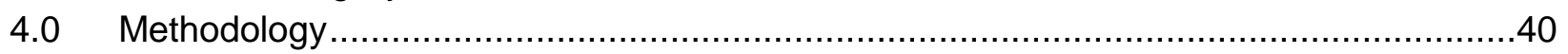

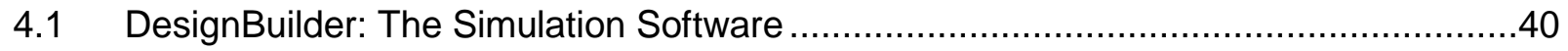

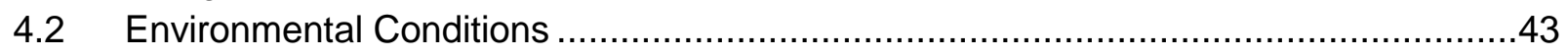

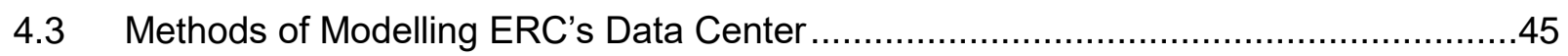

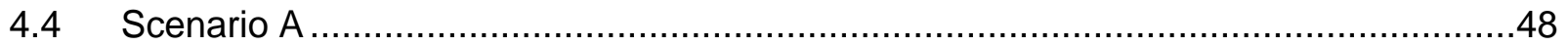

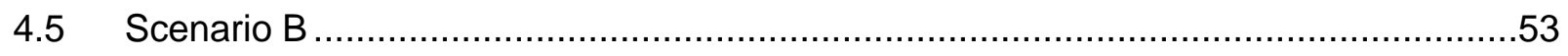

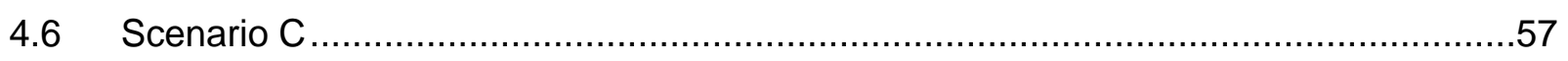

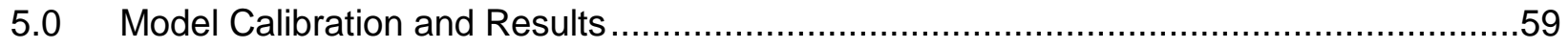

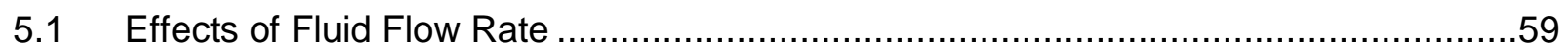

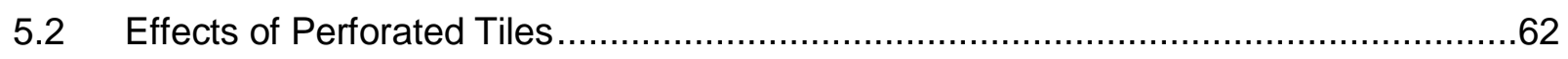

5.3 Heat Exchanger Temperature Verification ……..................................................65

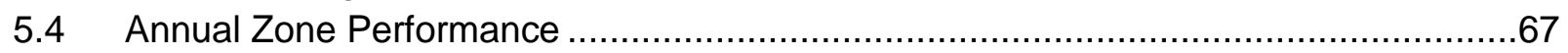

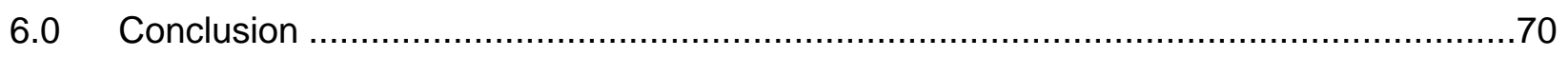

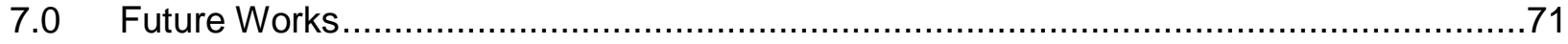

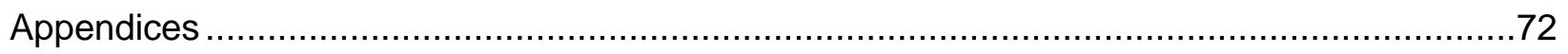

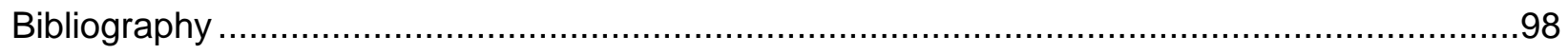




\section{List of Figures}

Figure 1 Worldwide ICT energy forecast by Anders Andrae 4

Figure 2 Hot aisle / Cold aisle configuration in data centers 5

Figure 3 (Left) Typical server rack arrangement and measurements, (Right) Server blade chassis

Figure 4 Predicted US data centers' total energy consumption per annum 8

Figure 5 Recorded trend of Power Usage Efficiency (PUE) at Google 9

Figure 6 Breakdown of server room's energy consumption 10

Figure 7 Idle power trend according to Specpower 11

Figure 8 Hot aisle/Cold aisle rack arrangement (left), Typical data center cooling system: CRAC

$\begin{array}{ll}\text { unit combined with the raised floor plenum (right) } & 13\end{array}$

Figure 9 Various cooling system methods by different coolant combination 14

$\begin{array}{ll}\text { Figure } 10 \text { Multi-zone modelling method of a data center proposed } & 17\end{array}$

$\begin{array}{ll}\text { Figure 11 Cooling water source heat pump - schematic graph } & 17\end{array}$

Figure 12 common temperature range of data centers components 21

Figure 13 District Heating Chain $\quad 23$

Figure 14 Earth Rangers Center 27

Figure 15 The Andover Continuum automation system combines different systems in an integrated platform. $\quad 29$

Figure 16 Total energy consumption breakdown of Earth Rangers Centre 30

Figure 17 Earth Rangers' Data Center 31

Figure 18 Ground Floor Plan - ERC 32

Figure 19 Three- dimensional sketch and measurements of the data center 32

Figure 20 Earth Rangers data center - Plan view 33

Figure 21 In-Row RC- ACRC100 - 50/60 Hz - 100-120v 37

Figure 22 Ground Source Heat Pump \& Heat exchanger 38

Figure 23 Illustration of Geothermal boreholes in the ground 38

Figure 24 Recorded daily temperature of outdoor air vs. geothermal output node recording 39

Figure 25 big picture of EnergyPlus $\quad 42$

Figure 26 ASHRAE thermal guideline for data center operating environment - SI Unit 44

Figure 27 Overall modelling strategy 45

Figure 28 Server racks electricity consumption breakdown (Recorded) 47

Figure 29 Scenario A system diagram, retrieved from DesignBuilder 48

Figure 30 General design of a geothermal heat pump system 49

Figure 31 Heat balance of miscellaneous loads at the peak in Scenario A 51

Figure 32 Zone Envelope Heat Balance $\quad 51$

Figure 33 Monthly total cooling rate of FCU - Scenario A 52

Figure 34 Indoor air temperature (Scenario A) 52

Figure 35 Scenario B, system diagram, retrieved from DesignBuilder 54

Figure 36 Monthly total cooling rate of FCU - Scenario B 55

Figure $37 \mathrm{DC}$ indoor air temperature in scenario B vs. Outdoor dry-bulb air temperature $\quad 56$

Figure 38 Scenario C system diagram, retrieved from DesignBuilder 57

Figure 39 Monthly total cooling rate of FCU - Scenario C 58 
Figure 40 Data center indoor air temperature in scenario $\mathrm{C}$

Figure 41 Component summary end use (effect of heat exchanger's fluid flow rate)

Figure 42 Effect of heat exchanger's fluid flow rate on zone means air temperature.

Figure 43 Monthly cooling energy rate in Scenario B and altered flow rate model

Figure 44 Illustrated perforated tiles in the 3D model

Figure 45 Effect of application of perforated tiles on zone mean air temperature

Figure 46 Component summary end - use (effect of applied perforated tiles)

Figure 47 Verifying HX-5 recorded temperature trend- Summer Design Week

Figure 48 Effect of reviewed proposed calibration methods relative to the base model $\quad 68$

Figure 49 HX-5 heat exchanger connecting Geothermal to Chiller/Heat Pump 72

Figure 50 HX-5 input/output temperature records (2018) 73

Figure 51 Monthly Weather Data - 2018

Figure 52 Daily Weather Data - 2018 


\section{List of Tables}

Table 1 Volume server power trend

Table 2 Individual and cumulative heating/cooling load indexes 16

Table 3 Possibilities of waste heat recovery according to facilities' cooling system 20

Table 4 Waste heat utilization application $\quad 22$

Table 5 Earth Rangers' rack No.1 components

Table 6 Earth Rangers' other racks' active components 35

Table 7 Racks heat dissipation breakdown $\quad 35$

Table 8 In-row RC (Rack Cooling) status on Jan 30th, 2019

Table 9 Class definitions for ITE environment 43

Table 10 Summary of ASHRAE thermal guidelines for data center 44

Table 11 Calculated HVAC design summary $\quad 50$

Table 12 Fluid-to-fluid heat exchanger component sizing in scenario B 59

Table 13 Comparative evaluation of end-use electric consumption among proposed strategies

\section{List of Abbreviations}

ASHRAE - American Society of Heating, refrigeration and Air-Conditioning Engineers

PUE - Power Usage Efficiency

CRAC - Computer Room Air Conditioner

$\mathrm{HX}$ - Heat Exchanger

$\mathrm{RC}$ - Rack Cooling

ERC - Earth Rangers Centre

ITE - Information Technology Equipment

DC - Data Center

CPU - Central Processing Unit

DRAM - Dynamic Random Access Memory

SRAM - Static Random Access Memory

HDD - Hard Disk Drive

SSD - Solid State Drive

DH - District Heating

ICT - Information and communications technology

ECM - Energy Conservation Measures

GSHP - Ground Source Heat Pump

COP - Coefficient of Performance 


\subsection{Introduction}

Building Energy management and $\mathrm{CO} 2$ emission reduction is a critical issue, especially with global warming phenomena and increasing growth of the information technology sector in our lives. According to global statistics, 1.1-1.5\% of the total energy used worldwide is consumed by data centers (Cronin, 2011). This figure has been predicted to increase 15-20\% each year until 2020 (Davies et al., 2016). Increasing energy cost have made many data center operators making many efforts to reduce the electricity consumption rate by implementation of more efficient IT equipment, high-performance data center cooling systems, building automation systems, etc.

Nevertheless, integration of one or two of those energy conservation methods may found useful in the optimization of the system but not enough relative to the ever-increasing trend of energy consumption in data centers. Consistent monitoring and evaluating of the building, machines and all the devices and their accuracy can help the building to last longer with the same or improved performance. In order to evaluate the performance of building in different situations such as temperature or higher data processing load in data centers, many researchers have been attempted to design models which can present the buildings' behaviours in various conditions.

Models can be based on rational relations or mathematical equations between inputs and outputs. Designing a fully functional model that can be the replica of the actual building in all the situations and conditions is a complex task because of the complexity of data centers and the fact that a designer should know all the variables that can impact the output and the relations between them. Developing studies based on real cases would assist researchers in expanding the base knowledge on the actual performance of operating data centers and path the way for future studies. This might be still challenging as there are either rare information about existing data centers or some vague data due to the high level of security in these facilities. By having pairs of input and outputs for the model and assistance of a capable building simulating software, a model can be developed that can predict the future behaviour of the building. This means these models can simulate and predict different measures in the seen and unseen conditions of the input such as doubled loads of servers or increase in cooling supply temperature. A good model can predict even rare conditions and able to evaluate their future performances. 
The challenge in designing a model is to have enough amount of data to use in machine learning approaches or to have enough knowledge of the building to develop the model with the assistance of computer-aided predeveloped software like EnergyPlus or DesignBuilder. Machine learning method can be the future of building simulation approach for even more complicated cases, and useful when not enough information is available.

Data center energy and cost management and measurement is an exciting task. The machines inside the building are large energy consumers and heat generators so that the building can potentially utilize this available source of energy. Having a model which can evaluate, monitor and simulate cost and the energy consumption in these kinds of facilities is necessary in order to optimize in the best way. The goal of this study is modelling a data center and calibrating variables and results based on limited available data from a real case study. The aim is to get the optimal output from the model and propose effective methods of calibrating a data center model.

In this study, DesignBuilder was chosen as the energy modelling software. DesignBuilder is a user interface of one of the most potent simulating manager engines (i.e. EnergyPlus). It offers a wide range of data sets and a user-friendly interface. The case study is a small data center performing in Earth Rangers Centre (ERC) in Woodbridge, Ontario. The data center's energy model has been developed based on collected data from the facility and assumptions made and recorded in this study. Regards to the fact that, this facility is continually under ongoing research studies and available complex and high-tech building's infrastructure, led researcher developing energy models with different HVAC scenarios to first, developing proper performance overview for the reader and operator, then propose available HVAC alternatives to stakeholders for potential changes in data center's infrastructure. Three design scenarios are presented and validated based on available data.

The data center energy model is expected to obtain indoor air quality similar to the status quo. Therefore, calibration methods in order to achieve desired performance trend are presented and discussed. This study is compatible and aligned with ambitious Earth Rangers' energy conservation target of making the data center a net-zero consumer or anywhere close to that. Benefiting from cold climate free cooling together with reuse of waste heat are expected to result in minimum energy demand. Investigation of different waste heat reuse applications specially designed for low-grade heat sources is recommended for future researches for this building. 


\subsection{Literature Review}

Before reviewing similar works done by other researchers, it is necessary to introduce and clarify some basics about the data centers. Understanding roles of Information Technology Equipment (ITE), their changes during time, and the way they are connected to each other and HVAC system, is an essential set of information for data center designers to become capable of managing to change the landscape of data centers. (Beaty \& Quirk, 2017)

Following paragraphs will explain a brief component overview of the data centers, the current state of energy consumption and popular cooling systems in DCs. Building energy modelling is one of the popular topics among researchers in order to investigate opportunities in energy saving and mitigating $\mathrm{CO} 2$ emission globally. Literature with the same framework, especially those concentrated on computer-aided simulation of data centers and their calibration based on reallife data were studied and reviewed. This follows by comprehensive review literature regards to possible heat reuse and recovery applications that might be suitable for further investigation about this case.

\subsection{Components and Configuration of Data Centers}

Data centers consist of different IT equipment, data halls, and supporting infrastructure. Data Centers are generally responsible for processing, storing and transferring data throughout the network (Davies et al., 2016). Influence of data and functionality of data centers are evident in our everyday life, from very simple processes like video streaming, web-based communications, and so forth. To the most complicated ones like the emergence of artificial intelligence (Al) and machine learning in the information technology sector. Davies et al. reported that approximately over 2 million server racks were operating in the UK, in 2016. While forecasts shows accelerating total energy demand by information and communications technology (ICT) in the 2020s. Anders Andrae declared that ICT grows to $8 \%$ of total worldwide electricity demand by 2030 , the and data centers take the larger share (Source: www.nature.com). 


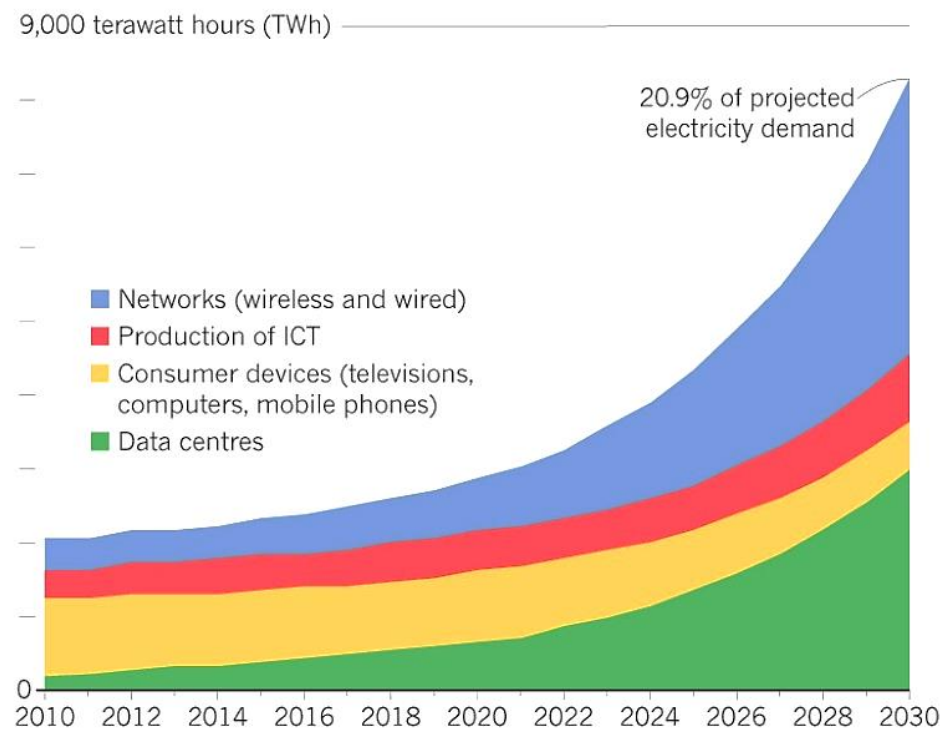

Figure 1 Worldwide ICT energy forecast by Anders Andrae (Reproduced image, source: www.nature.com)

In general, there are three types of IT equipment that shape a data center: Servers, storage, and networking.

Servers, networking devices, and cables organize and fits in a solid steel framework called Racks (or Cabinets). The most common arrangement of racks in data centers is in such a way that placing them in rows which are typically $4 \mathrm{ft}$ apart and forms rows up to the pitch of almost $2 \mathrm{~m}$ in length (Ebrahimi et al., 2014).

Hot aisle/Cold aisle arrangement is the most common configuration of all time which can be found in almost all data center (DC) layouts. It contains cabinet rows which face each other and form cold aisle in between and hot aisle at the back side. Air releases to the hot aisle have the highest temperature of all room (Ebrahimi et al., 2014). This arrangement method helps to manage airflow as well as providing maintenance access for the staff. Also, it helps to reduce the potential mixing of cold/hot air streams (Hallett \& Paunon, 2014). Over time, in more extensive facilities, containment method is used and found useful at times, as it leads to minimum air mixing and complete separation of designated aisles. Even though the containment system referred to an unnecessary method for racks with lower 10kW density (Hallett \& Paunon, 2014). 


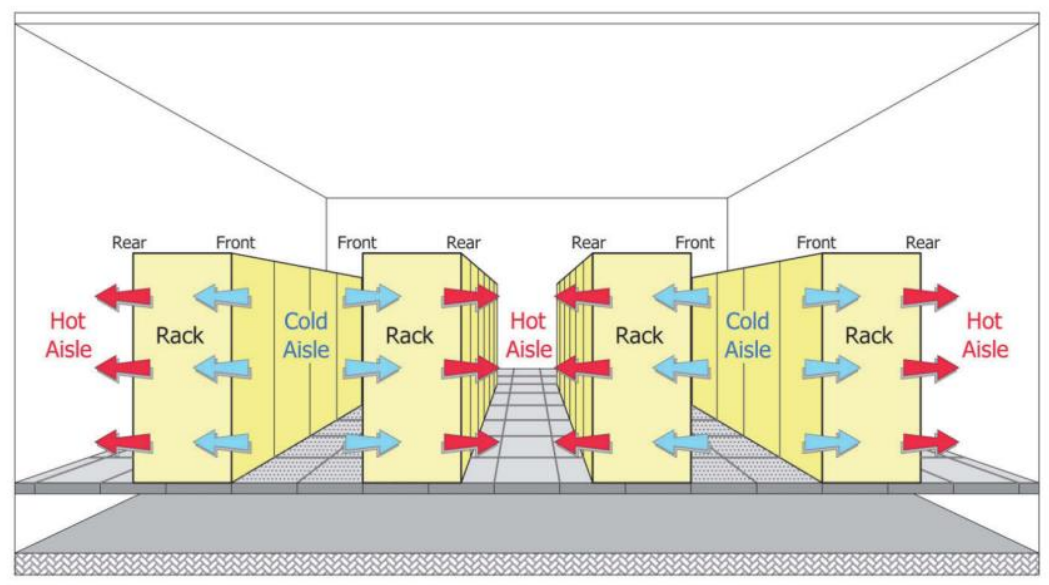

Figure 2 Hot aisle / Cold aisle configuration in data centers (Ref: Datacom Equipment Power Trends and Cooling Applications-2nd Edition, 2012)

EIA-310 (Electronic Industries Association) specified "standard rack" as a universal sizing for rack mounted equipment. Standard racks are $432 \mathrm{~mm}$ (17") wide (Dimensions varies slightly in different literatures) and the unit of measurement for blade thickness (height) is set as $44 \mathrm{~mm}(1.75$ ), named "U." Servers are usually placed horizontally covering the full width of the cabinet. However, recently servers have been manufactured in half-width version as well for more compactness. Another trend in manufacturing of servers is ones with more than two socket processors which occupies more than $1 \mathrm{U}$ in height. Figure 3 clearly illustrates the modulated size of manufacturing equipment that fits in racks without waste of space. A full height rack can house $42 \mathrm{U}$ modules in total (The Server Rack FAQ, 2007) (Ebrahimi et al., 2014) (Datacom Equipment Power Trends and Cooling Applications-2nd Edition, 2012).

Figure 3 (Right image), illustrates an alternative server arrangement where server blades are placed vertically, in a self-contained enclosure called chassis. They are equipped with separate power, fan, etc. Moreover, in terms of capacity, 8 to 16 server blades can be placed in a chassis for greater compactness. Chassis height is typically between $3 \mathrm{U}$ and $7 \mathrm{U}$ (Datacom Equipment Power Trends and Cooling Applications-2nd Edition, 2012) (Kant, 2009).

Kant (2009) has specified different full-rack capacity. Up to 64 ( (ASHRAE, 2017)), 84 (Ebrahimi et al., 2015) or 96 (Rahmani et al., 2017) are the cases noted in the mentioned literature. Thus, the size of servers and chassis measurements have profoundly affected the variation of power intensity in racks (Kant, 2009). 

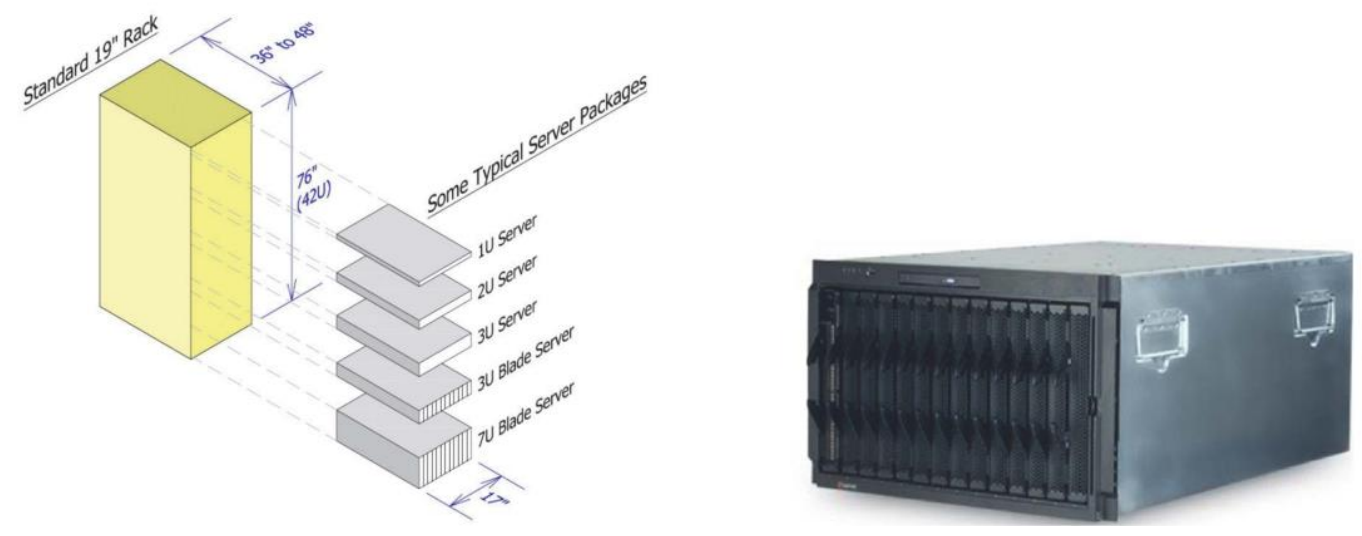

Figure 3 (Left) Typical server rack arrangement and measurements, (Right) Server blade chassis (Ref: Datacom Equipment Power Trends and Cooling Applications-2nd Edition, 2012)

Servers are responsible for processing data and providing utility to the clients.

Blade server units occupy $3 U$ to $10 \mathrm{U}$ in height and typically 19" wide. However, in recent years for achieving higher density, some manufacturers provide half-width units as well.

Heart of a server is known as Central Processing Unit (CPU), which centred on the motherboard with memory and storage surrounding it. Volatile memories (SRAM and DRAM) hold inputs and outputs from CPU and store data eventually in non-volatile storage units; HDD, SSD, and Tapes are storage components at this point.

Servers are the most energy consumers among other Information Technology (IT) equipment in data centers. Due to continuous performances of millions of switches per second in a CPU, a considerable amount of electricity consumption is required. Moreover, consequent heat generation by servers is considered the highest compared to other components (Beaty \& Quirk, 2017).

Networking is responsible for maintaining all interconnections within data center resources and outside the data centers.

Networking connection is provided by switches organized in a hierarchy, in the order of core, distribution and edge switches (Beaty \& Quirk, 2017). Besides, networking has been evolving so fast, and contrary to traditional network approach, today's software-defined networking (SDN) solves dynamic demands.

Storage in data centers is intended to store data for one of the following four reasons: 
- Online storage (for rapid accessibility)

- Backup (for data loss prevention)

- Archiving (for long-term storage)

- Disaster Recovery (requires different physical location)

\subsection{Data Center's Energy Consumption}

Data Centres are known as one of the large energy consumers. Cronin, D. (2011) reported that worldwide data centers were responsible for 1.1 to 1.5 percent of total electricity usage worldwide. Moreover, that used in US accounted for 1.7 to 2.2 percent. Between 1998 to 2010, the number of data centers in US surged from 432 to 2094, which showed considerable growth. It also stated that electricity usage of DCs in 2006 doubled that of in 2000 (Ebrahimi et al., 2014).

Regarding the growth trend of data centers, Ebrahimi et al. declared data center market growth would result in possibly 15-20\% increase in power demand per annum (2014). From a different perspective, the data processing demand predicted to get doubled every two years until 2020 (Gantz \& Reinsel, 2013). In contrast, Shehabi et al. (2016) claimed the trend of energy consumption by data centers in the United States had been flattened in the past years as a result of improved efficiencies and new upgraded data centers. Figure 4 illustrated, the historic static trend of energy efficiency in 2010 vs. projected energy consumption through 2020 by applying five optimization strategies. Total energy consumption includes energy used by servers, storage, network, and other infrastructure. As can be seen, if data centers' infrastructure and management remain unchanged, the energy use could grow as fast as internet demand growth. So, any efforts through more efficient data centers is a very big deal. 


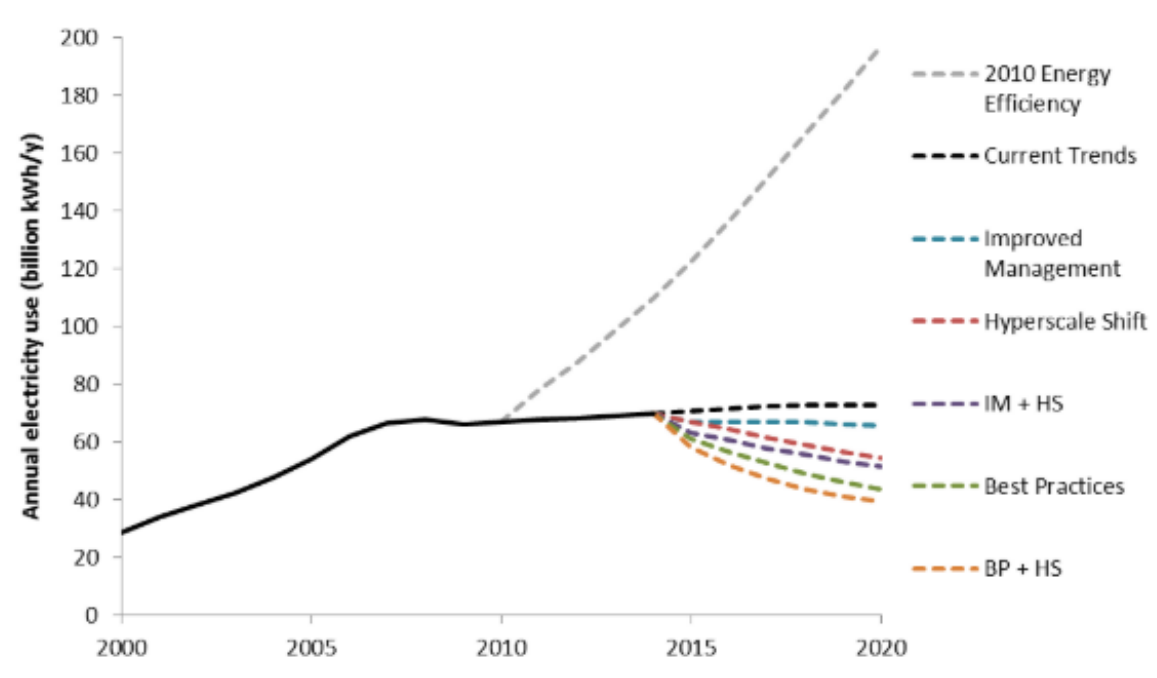

Figure 4 Predicted US data centers' total energy consumption per annum. "Improved Management (IM), Best Practices (BP), Hyperscale Shift (HS)" (Ref: Shehabi, et al., 2016).

A large data center facility like Google could have a big impact on worldwide energy use. However, such facilities, with employing cutting-edge cooling strategies, like benefiting from evaporative cooling and free cooling when possible, instead of constant mechanical chiller use, reduced their energy consumption considerably. Integration of smart temperature control, smart energy distribution to eliminate excessive loss, and lighting control, all contributed to result in better performing data centers in terms of energy efficiency. Besides developments in infrastructure, high-performance servers have lowered energy use noticeably. Google's data centers were reported consuming half of average data centers (Gao, 2014).

Power Usage Efficiency (PUE) is defined in the international standard ISO/IEC to assist operators in understanding the efficiency of a data center. The ratio of total data center power input to the amount of power used by IT equipment defines this metric. Koomey (2010 cited by Avgerinou et al., 2017, page.6) projected a range of PUE values among 61 data centers based on the Energy Star program of Environmental Protection Agency (EPA). Numbers scattered from 1.25 to 3.75 with an average value on 1.92. Three years later, Uptime Institute (2013 cited by Avgerinou et al., 2017, p.6) reported an average PUE of 1.65 from self-reporting participants. And, Phan \& Lin (2014) declared the power density of data centers have been growing continuously.

On the other hand, Figure 5, depicts continues improvement in average PUE for all data centers at Google between 2008 and 2013, reducing from 1.21 to 1.12, respectively. Gao (2014) has developed a machine learning model and piloted it at multiple data centers including Google. $40 \%$ 
reduction in energy consumed in cooling and a 15\% reduction in overall energy resulted after 18 months. Gao demonstrated that machine learning is a very effective method for data center modelling and resulting energy efficiency improvement analysis. Results show that there is a downward trend in the average data center's PUE (Gao, 2014).

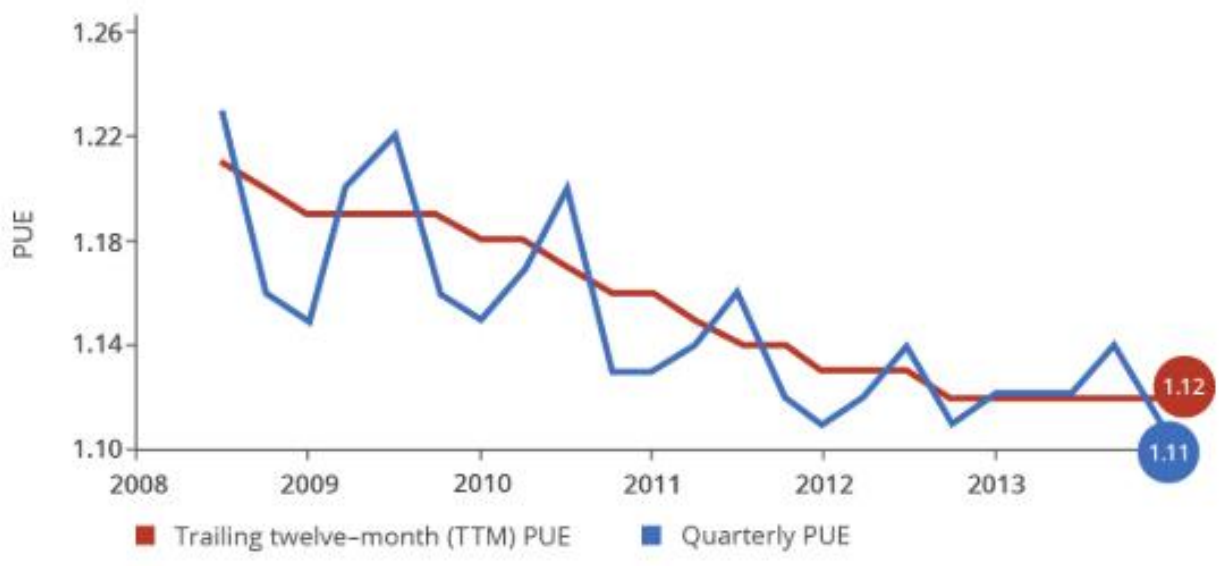

Figure 5 Recorded trend of Power Usage Efficiency at Google (Gao, 2014)

According to records, rise in energy consumption intensity of servers due to associated growth of dependency to data processing and cloud base storages, today's server racks consumes 30 times electricity comparing to typical usage in 1990 (Ebrahimi et al., 2014). Same growth also applies to the resulted in waste heat. As almost all electricity consumed by servers converts to heat and dissipates to the surrounding. Traditional data centers heat dissipation was in a range of 430-861 $\mathrm{W} / \mathrm{m}^{2}$, while in newer generations this increased more than ten times to $6458-10,764 \mathrm{~W} / \mathrm{m}^{2}$ (Rasmussen, White Paper 120. Schneider Electric). The idea of making use of this free, valuable source of energy had been around in recent years. However, the quality of heat exhausts from data centers varies. Moreover, there is not a single answer for the viability of this alternative heat resource.

Energy transferred to data centers is used mainly for powering IT servers and cooling equipment. Generally, almost half of the electricity is consumed by IT equipment, and the majority of the rest (approximately $40 \%$ ) is used by cooling infrastructure. Lighting and other miscellaneous loads are not very significant in comparison (Figure 6). Pan et al. (2008) showed when an office building combined with a data center, integrates a range of high-efficiency building systems, servers and other involved equipment in server room become the major electricity consumers. They accounted for $84 \%$ of total electricity used in the whole building. 


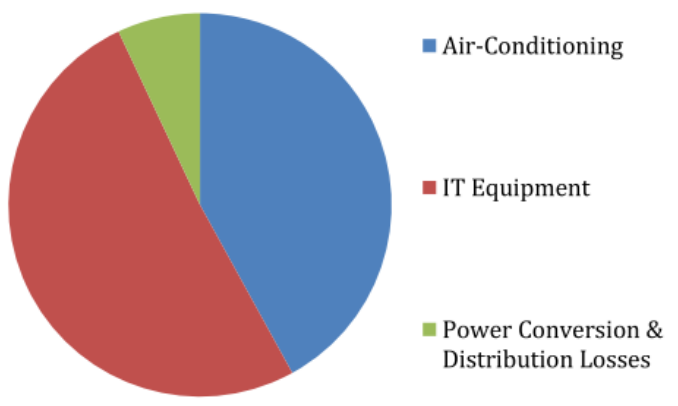

Figure 6 Breakdown of server room's energy consumption (Ref: Jinkyun Cho et al. cited by Jadhav \& Chaudhari, 2015, p.232)

The power trend for servers between 2010 and 2020 is shown in Table 1 looking at a full rack density (42U), high-density racks estimated to require a high level of power. It was also warned that possible major cooling issue might happen for rack loads above 15 to $20 \mathrm{~kW}$. Localized liquid-cooling considers as one good option follows by high-performance air-cooling ventilation method, which could perform viably (Datacom Equipment Power Trends and Cooling Applications-2nd Edition, 2012).

Table 1 "Volume server power trend" (Ref: Datacom Equipment Power Trends and Cooling Applications-2nd Edition, 2012)

\begin{tabular}{|c|c|c|c|c|c|c|c|c|c|c|}
\hline \multirow{2}{*}{ Type } & \multicolumn{3}{|c|}{ Size } & \multirow{2}{*}{$\begin{array}{c}\text { Range of } \\
\text { Average } \\
\text { Heat Loads }\end{array}$} & \multicolumn{3}{|c|}{$\begin{array}{l}\text { Heat Load/Chassis } \\
\text { (W) }\end{array}$} & \multicolumn{3}{|c|}{$\begin{array}{l}\text { Heat Load/42U Rack } \\
\text { (W) }\end{array}$} \\
\hline & w & $\mathbf{H}$ & Sockets & & 2010 & 2015 & 2020 & 2010 & 2015 & 2020 \\
\hline \multirow{9}{*}{ 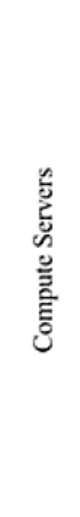 } & \multirow{9}{*}{$\begin{array}{l}17.5 \text { in. } \\
(0.44 \mathrm{~m})\end{array}$} & & is & $\pm 20 \%$ & 255 & 290 & 330 & 10,710 & 12,180 & 13,860 \\
\hline & & $1 \mathrm{U}$ & $2 \mathrm{~S}$ & $\pm 10 \%$ & 600 & 735 & 870 & 25,200 & 30,870 & 36,540 \\
\hline & & & $4 S$ & $\pm 5 \%$ & 1000 & 1100 & 1200 & 42,000 & 46,200 & 50,400 \\
\hline & & S & $2 \mathrm{~S}$ & $\pm 20 \%$ & 750 & 1100 & 1250 & 15,750 & 23,100 & 26,250 \\
\hline & & 20 & $4 S$ & $\pm 5 \%$ & 1400 & 1800 & 2000 & 29,400 & 37,800 & 42,000 \\
\hline & & $4 U$ & $4 S$ & $\pm 5 \%$ & 2300 & 3100 & 3300 & 23,000 & 31,000 & 33,000 \\
\hline & & $7 \mathrm{U}$ (Blade) & & $\pm 10 \%$ & 5500 & 6500 & 7500 & 33,000 & 39,000 & 45,000 \\
\hline & & $9 \mathrm{U}$ (Blade) & $2 \mathrm{~S}$ & $\pm 10 \%$ & 6500 & 8000 & 9500 & 36,000 & 32,000 & 38,000 \\
\hline & & 10 (Blade) & & $\pm 10 \%$ & 8000 & 9000 & 10,500 & 32,000 & 36,000 & 42,000 \\
\hline
\end{tabular}

The energy used by servers is not constant. The dynamic flow of input to the servers gives out similar output energy consumption. Dynamic behaviour of servers can be the result of a dynamic load on servers. Servers usually are not used at full capacity, and there are times that some servers kept with no load (Idle mode). Contrary to what might be expected, servers in idle mode 
consume considerable energy. Substantially, a data center working with full load capacity has better thermal performance comparing to that kept on idle mode. Full load performing servers can generate more heat, and more waste heat reuse can result. All said leads to higher efficiency (Zimmermann et al., 2012). Indeed, as it seems this portion of used energy is useless. These are some opportunities that found valuable by researchers in order to achieve more efficient data centers.

According to the above statements, there have been two possible chances to improve overall efficiency (using servers at higher capacity and minimizing the number of servers at idle mode). This makes a data center, having fewer servers, consumes less or keeping the status quo and increase the output with the same number of servers. Both lead to a more efficient data center. Hopefully, as can be seen in Figure 7 regarding SPECpower-ssj2008 as power-performance benchmarks, servers idle power usage is estimated to lowers gradually after 2009 through 2020. This shows success in new designs of servers and processors. As Idle power is very dependent on different aspects of the server designs. The significant changes occur after any corresponding design change in servers and processors. (Datacom Equipment Power Trends and Cooling Applications-2nd Edition, 2012)

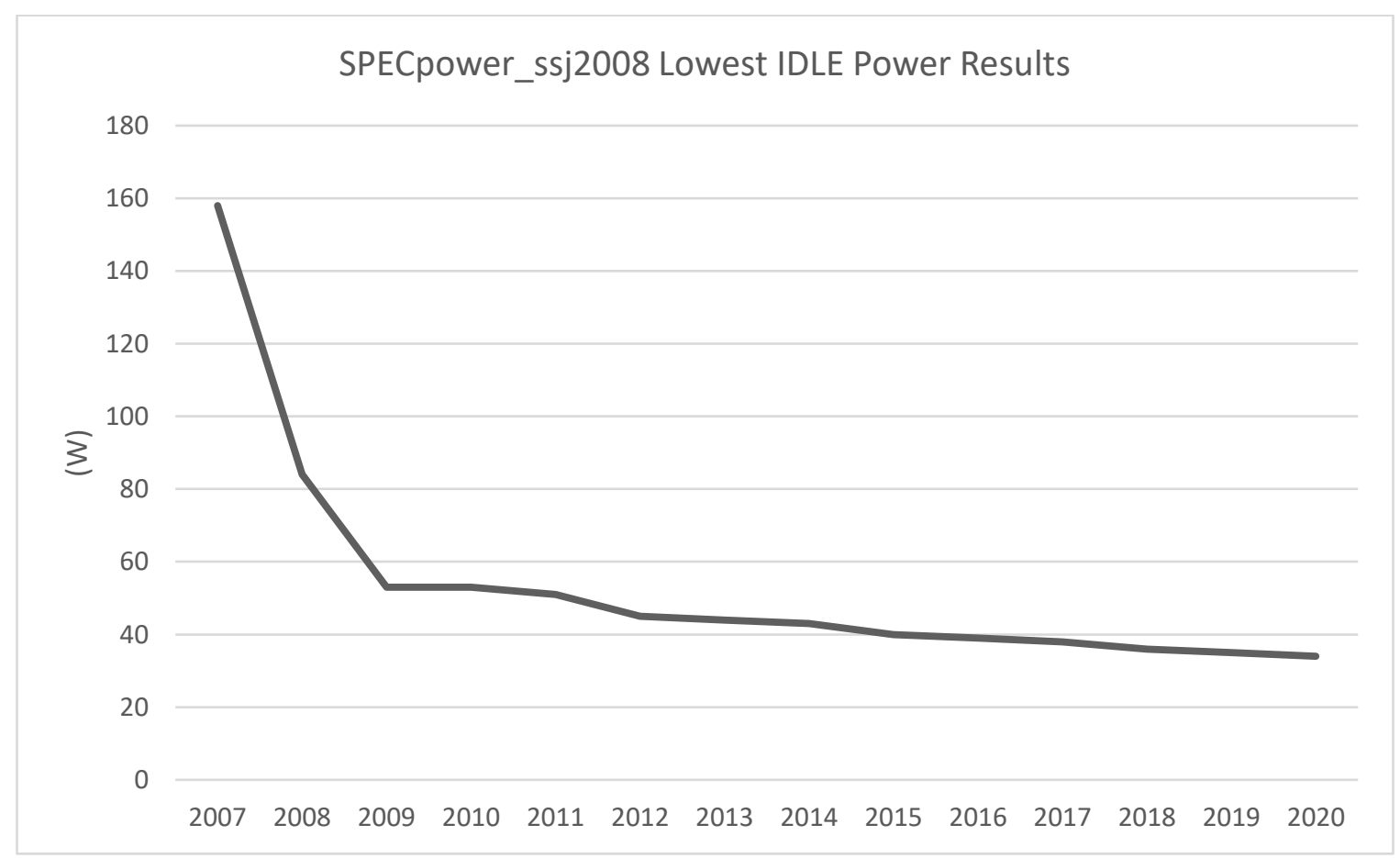

Figure 7 Idle power trend according to Specpower (Reproduced from source: Datacom Equipment Power Trends and Cooling Applications-2nd Edition, 2012) 


\subsection{Data Center Cooling Technologies}

Data centers are large electricity consumers. Almost all energy used by IT servers turns to heat and needs to be removed from the space. Cooling systems are ultimately designed to transfer excessive heat out and condition the datacom environment. Heat removal is possible from the underfloor plenum, overhead ducts, in-row systems or direct cooling at CPU's perimeter (Hallett \& Paunon, 2014). In order to keep continuous reliable and efficient performance in DCs, servers surrounding temperature should be maintained within a specific range, $18-27^{\circ} \mathrm{C}$ (ASHRAE, 2017).

Cooling solutions are mechanical cooling, free cooling, or a combination of both, although free cooling has its limitations which are not the best choice in all climates. However, it has proven as a reliable system in cold climates. Data center facilities showed lower cooling demand in Nordic countries, and having very efficient power effectiveness (Avgerinou et al., 2017). Depoorter et al. (2015, cited by Wahlroos et al., 2018, p.1750) declared the implementation of direct cooling had saved up to $8 \%$ of electricity usage, relative to the location. There are other emerging technologies for cooling. Namely, they are liquid cooling, district cooling, two-phase cooling, and free cooling (Wahlroos et al., 2018).

Current mechanical cooling technologies used the most in datacom facilities can be categorized into two major groups: air cooling and liquid cooling.

Air cooling is known as the most used approaches in data centers. In air-cooled data centers, Computer Room Air Conditioner (CRAC) unit and Computer Room Air Handler (CRAH) unit, located inside the IT room, are responsible for cooling and conditioning of the air. Figure 8 illustrates a commonly used rack configuration of data centers. In hot aisle/cold aisle configurations, hot and cold aisles are alternating between the server rack. In cold aisles, the front side of the racks faces each other where cold air delivers to equipment intake. Cool air is blown into the cold aisle from local air distribution or underfloor or overhead (Datacom Equipment Power Trends and Cooling Applications-2nd Edition, 2012). Air passes through the servers and absorbs heat and exhausted out to the back side (hot aisle) via fans. Eventually hot air transfers back to the air handling units and cools by passing through the coils containing coolant that connected to an outdoor condensing unit. Then the cycle repeats (Oro et al., 2015) (Ebrahimi et al., 2014). 

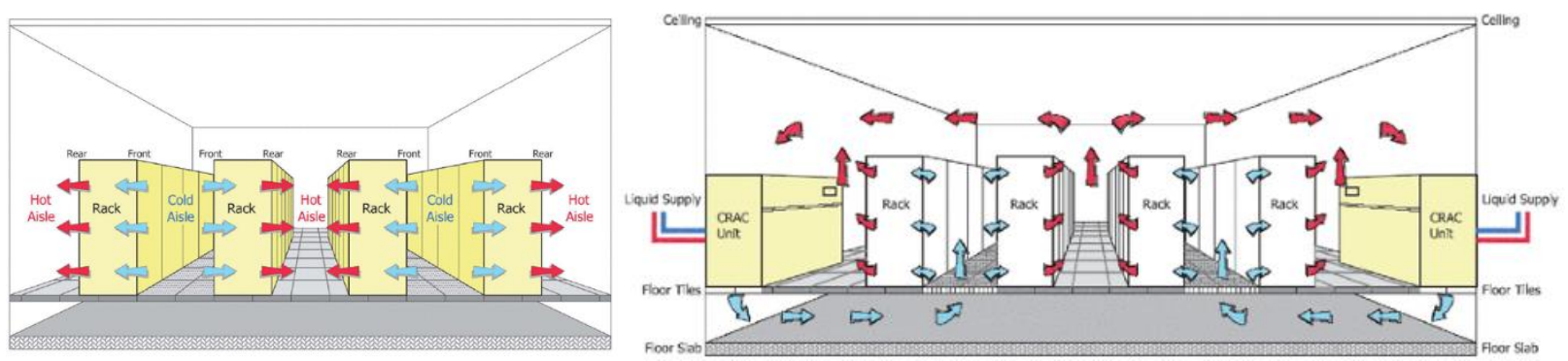

Figure 8 Hot aisle/Cold aisle rack arrangement (left), Typical data center cooling system: CRAC unit combined with the raised floor plenum (right) (Avgerinou et al., 2017)

Thermal performance of an air-cooled server room is directly affected by air flow and the way it has managed. The performance of air-cooling technology has been improved considerably in the past years. However, there have been minor issues in air-cooled systems which affects the efficiency of the system. Airflow recirculation (Ebrahimi et al., 2014), hot spot formation (Datacom Equipment Power Trends and Cooling Applications-2nd Edition, 2012), efficiency drop associated with the temperature drop in servers installed in higher levels (mostly occurs in underfloor air distribution method) (Galli, 2018), and so forth. Jadhav \& Chaudhari (2015) aimed to verify methods of optimizing DC energy performance and achieving improved air-flow management. $\mathrm{RTI}$ (Return Temperature index) and $\mathrm{RCI}$ (Return Cooling Index) metrics have been used to identify air by-passing or re-circulation, and effectiveness of cooling center, respectively. Moreover, by employing of containment method/cabinet cooling roughly $15 \%$ improvement in server room's total efficiency is resulted. Oró et al. (2016) investigated a real data center case study, where air recirculation and hotspots were noticed. The effect of air-flow management in thermal efficiency and operating cost of the facility has been studied. By use of dynamic modelling and relevant air metrics, the study showed energy consumption lowers as higher temperature air supplied to the servers along with lower air flow rate.

In data centers, cooling demand approximately constitutes $40 \%$ of total power being consumed (Figure 6). Therefore, any energy conservation in this sector would substantially lower total data center power usage, several researches regards to this matter proofs its value and reputation among researchers. Davies et al. (2016) addressed some conservation methods complying aircooled systems. They are as follows,

- Hot aisle / cold aisle containment

- Eliminating hot spots, recirculation, and bypass

- Integration of free cooling

- Evaporative cooling 
Liquid cooling technique becomes useful when the air cooling system is hardly able to condition higher density super-computers of datacom facilities in an efficient manner. Liquid cooling is implemented in the system either as an on-chip or in-chip method (Davies et al., 2016). Heat sink fluid-filled pipes placed very close to the hottest server components. Alternatively, those electronic components with highly concentrated heat load can get immersed in cooling fluid.

Water, Glycol mixture, refrigerant and fluorocarbon fluids are the liquid coolants used in datacom facilities. What makes liquid cooling more viable than air cooling is, its higher heat capacity, a better performance where there are acoustical limitations and higher resulting efficiency in server rooms with higher heat density (Datacom Equipment Power Trends and Cooling Applications-2nd Edition, 2012).

On-chip liquid cooled servers couples with air-cooled systems for general cooling of the facility is one of the most effective cooling methods for efficient cooling. The closer coolant fluid is CPUs as the highest heat generating equipment of servers, more efficient heat removal is obtained. Liquid coolant is in charge of maintaining server's CPU and memory in recommended temperature range provided by the manufacturer, while local air cooling performs at much lower load to condition the whole server room area (Davies et al., 2016). Alternatively, server boards can immerse completely in liquid coolant, for direct heat removal. In this approach, regular close maintenance is required for eliminating any leakage potential (Davies et al., 2016).

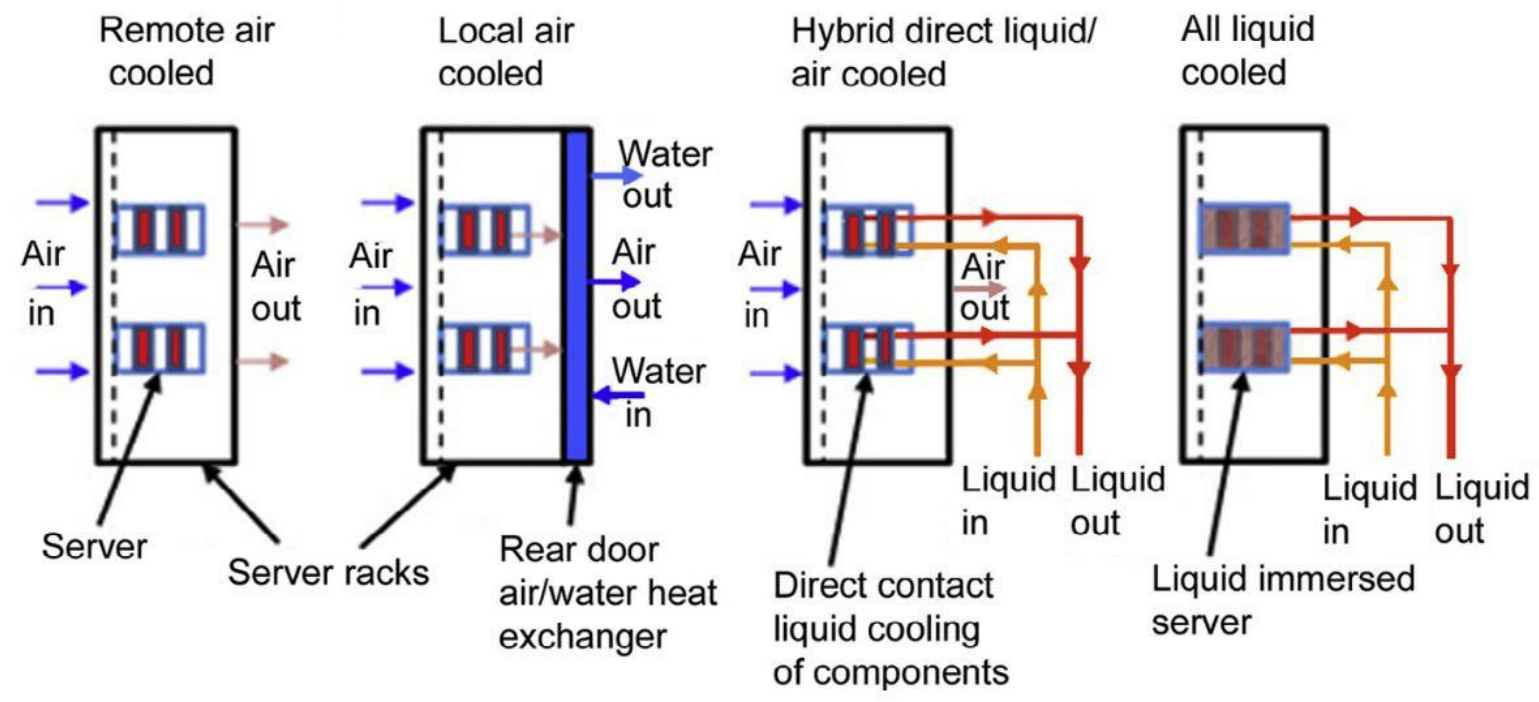

Figure 9 Various cooling system methods by different coolant combination [Ref: Davies et al., 2016] 
Since cooling is the second largest power consumer in DC facilities, researchers made efforts to identify best practices cooling system in data centers. However, there is not a single cooling method that can have an outstanding result in all situations. Various factors and parameters should be considered before choosing the most suitable cooling system (Davies et al., 2016). Hallett \& Paumen (2014) summarized methods of controlling data center thermal condition. The results showed that higher supply air temperature leads to a reduction of cooling demand through:

- Increasing temperature chilled water

- Chance of using economizer cooling

- Reducing PUE index (power usage Effectiveness)

\subsection{Energy Modelling}

Building performance assessment can be achieved by computer-aided simulation software or onsite experimental assessment. Due to the complexity of a building, computer simulation is known as an effective method of building performance assessment. This method is valuable in the assessment of the thermal performance of buildings as well as evaluation of energy conservation measures (ECM) effectiveness and their economies in existing and retrofit projects. With respect to energy modelling applications in data center performance assessment, there are limited available studies dedicated to data centers' energy modelling (Phan \& Lin, 2014).

Deymi-Dashtebayaz \& Valipour-Namanlo (2019) utilized DesignBuilder energy modelling software to assess thermal load and energy consumption breakdown of an office combined with a data center. Also, Pan et al. (2008) used EnergyPlus for developing energy simulation of two office buildings encompassing data centers in Shanghai, China. The energy model was used for evaluation of cost saving associated with four green energy saving measures (ECM) in comparison with baseline buildings (i.e. ASHRAE 90.1-2004 and China Code). They have found that energy saving up to $27 \%$ from China Code buildings and 21\% from ASHRAE budget buildings can be achieved by employing proposed design options. Among all ECMs, air-side economizer had been the most effective measure following by implementing ice storage strategy. Building envelope, lighting \& daylighting optimization methods also showed improvements in total results. 
Designer's Simulation Toolkit (DeST) is another energy simulating software that has been used by Peng et al. in the evaluation of an office building energy consumption. With the assistance of this computer-based tool, comprehensive study over the thermal effect of the building envelope, fresh air volume, and so forth on the evaluated annual energy consumption, has been conducted. Results enabled Peng et al. to propose practical energy-saving actions for optimization of the building (2014).

In 2019, DeST was used for simulation of the broader neighbourhood in Harbin, China, comprising building categorized in 6 different sectors plus a large data center. The main objective was evaluating potential data center's energy-saving effects. Referring to Table 2, the cooling and heating load index of data room and other zones were calculated (i.e. $775 \mathrm{w} / \mathrm{m}^{2}$, data room cooling load index). Large data center's cumulative cooling load, approximately 512 million kWh, represented huge heat reuse opportunity (Yu et al., 2019).

Table 2 - Individual and cumulative heating/cooling load indexes (Reroduced from source: Yu et al., 2019)

\begin{tabular}{|c|c|c|c|c|c|}
\hline Building & data room & $\begin{array}{l}\text { office } \\
\text { building }\end{array}$ & apartment & $\begin{array}{l}\text { canteen } \\
\text { fitness } \\
\text { center }\end{array}$ & $\begin{array}{l}\text { fitness } \\
\text { center }\end{array}$ \\
\hline Cooling load index $\left(\mathrm{W} / \mathrm{m}^{2}\right)$ & 775 & 62 & 77.5 & 112.4 & 63.2 \\
\hline Heating Load Index $\left(\mathrm{W} / \mathrm{m}^{2}\right)$ & 0 & 140 & 141 & 179.8 & 148.7 \\
\hline $\begin{array}{l}\text { Cumulative cooling load index of } \\
\text { air conditioning season }\left(\mathrm{kWh} / \mathrm{m}^{2} . \mathrm{a}\right) \\
\text { Cumulative heating load index of }\end{array}$ & 6640.1 & 26.1 & 34.3 & 58.1 & 35.6 \\
\hline air conditioning season $\left(\mathrm{kWh} / \mathrm{m}^{2} . \mathrm{a}\right)$ & 0 & 145.8 & 376.1 & 216.5 & 191.1 \\
\hline \multicolumn{6}{|l|}{ Total cumulative cooling loads } \\
\hline (kWh/a) & $512,748,522$ & 979,272 & 720,300 & 342,790 & 405,840 \\
\hline \multicolumn{6}{|l|}{ Total cumulative heating loads } \\
\hline (kWh/a) & 0 & $5,470,416$ & $7,898,100$ & $1,277,350$ & $2,178,540$ \\
\hline
\end{tabular}

Hong et al. (2008, cited by Phan \& Lin, 2014, p.365) validated two energy modelling software output. Results showed the same approximate results (within $-0.4 \%$ to $8.6 \%$ differential range) obtained from the simulation of one data center in EnergyPlus and DOE 2.2.

In 2014, Phan \& Lin proposed a new approach to simulate a data center, i.e. multi-zone modelling method (Figure 10). Contrary to other literature that considers server room as a single zone, Phan \& Lin took into account the influence of hot aisle / cold aisle characteristics on the overall thermal performance of the data center. 


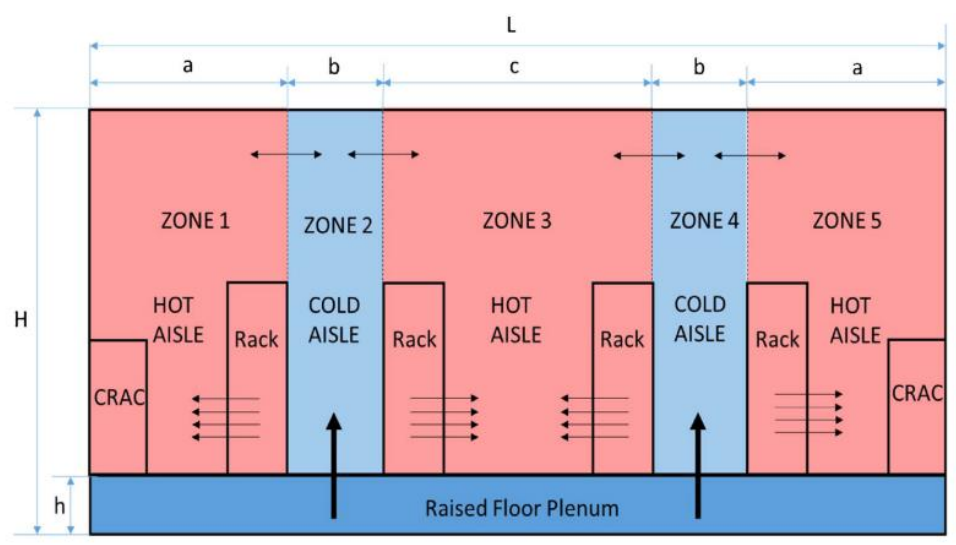

Figure 10 Multi-zone modelling method of a data center proposed by Phan \& Lin (2014)

Recently, Yu et al. (2019) have proposed and modelled a heat recovery system for a data center that serves other buildings. Serving hot water heat source for other buildings, with the integration of water-water heat pump in the system (Figure 11). Results showed this system would have a better economic outcome comparing to implementation of an air source heat pump.

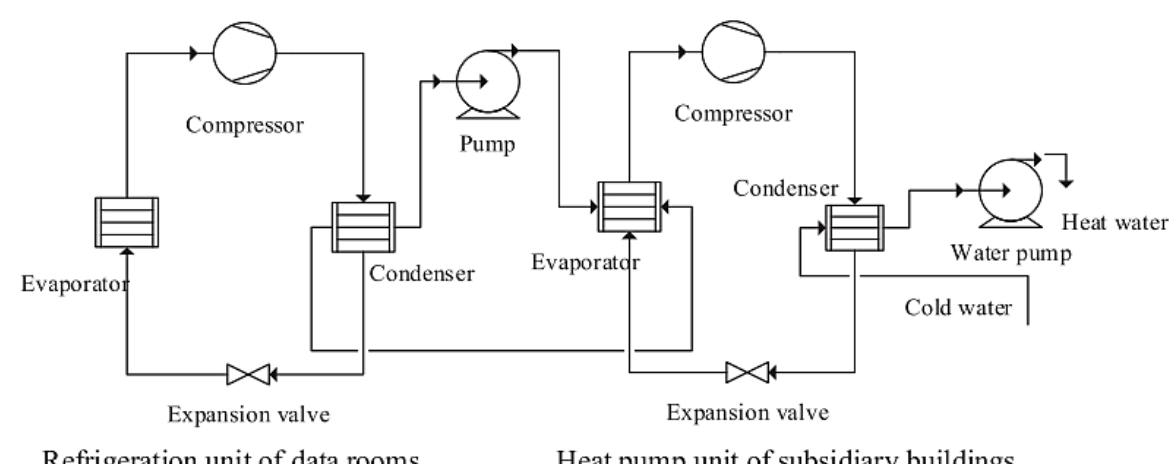

Figure 11 Cooling water source heat pump - schematic graph (Ref. (Yu et al., 2019))

The use of dynamic energy model using TraNsient System Simulation program (TRNSYS) helped Oró et al. (2016) analyzing the effect of improving airflow efficiency in a data center. The model has been validated by real data collected from the data center. Gao recommended integrating machine learning in data center modelling to accomplish more viable results relative to the dynamic behaviour of data centers (2014).

Building energy modelling is not only for monthly/annual energy consumption estimation and their associated costs but also, in case of data centers, it would enable operators to know whether they can reuse waste heat or not and evaluate the quantity and quality of that heat. 
Noting that, the kind of software being used is key to this information. In 2019, DeymiDashtebayaz \& Valipour-Namanlo developed waste heat recovery analysis besides economic evaluation of reusing heat from a 54-rack data center in Mashhad, Iran. Waste heat was designed to be used in a nearby office building for the purpose of space heating (Office area: $416 \mathrm{~m} 2)$. Thermodynamic analysis of the data center with implemented air source heat pump (ASHP) as a heat recovery tool, disclosed the following potential returns.

- Natural gas saving: $35000 \mathrm{~m} 3 / \mathrm{y}$

- Electricity saving: $20.8 \mathrm{MWh} / \mathrm{y}$

- CO2 emission reduction: 121 tons/y

- Total saving: $\$ 25000$

- Payback period: 2.5-7 Years

\subsection{Heat Recovery and Reuse}

Global warming is what is heard very often these days from news, people, and studies. The fact of limited fossil fuel reservoirs, people's increasing energy consumption each day and increasing the cost of energy are among reasons that raised scientist attention towards the discovery and development of further sources of energy. Green resources and waste heat reuse are among those that are more popular now (Ebrahimi et al., 2014).

Data centers are one of the large energy consumers with a predicted upward trend towards higher load density (Phan \& Lin, 2014). Data is only a series of 0's and 1's. But the process of manipulating trillions of them requires significant electricity consumption which eventually releases in the form of heat (Beaty \& Quirk, 2017). Big energy consumers have shown significant saving opportunities. Energy conservation opportunities are among the following criteria: 1) development in high-performance servers, 2) more efficient cooling system, 3) integrating green energy sources, and 4) recycling waste heat. These measures could compromise a tremendous consumption rate and lower power usage effectiveness metric.

Typically used methods for increasing performance efficiency of a data center, has been concentrated on the application of measures to improve the cooling system or in more complicated cases, integration of sustainable energy sources. Although, in recent years, scientists started to look at this system from another perspective and have valued waste heat and its possible recycling and reuse applications more. 
In data centers, heat dissipated from racks is collected, transferred and freely releases into the outdoor environment. In other words, high-temperature molecules of air carry out significant free source of energy out of the system, when they can be beneficial in some way. Various heat recovery methods are available. Although there are parameters like heat quality, reuse application, capital cost, etc. that affects the final choice. If the proper method is chosen and implemented in the system, a significant source of heat will become available worldwide.

Waste heat reuse is not a single method or application; different scales and methods are depending on a variety of system characteristics (Wahlroos et al., 2018). Wahlroos et al. also identified the low quality of captured heat, and high investment cost is the most significant barriers for this method (2018).

Wahlroos et al. conducted an overview of a data center located in Finland. Waste heat reuse in this case and similarly in other Nordic countries are best used in the district heating network. Similarly, Davies et al. 2016 highlighted the benefits of integrating DC waste heat in district heating network. This study acknowledged data centers as the second-best heat source of London's Future. With waste heat utilization of a 3.5 MW Data Center in London, in DH network, saving of more than 400 tonnes of $\mathrm{CO} 2 \mathrm{e}$ and approximate $£ 1$ million is projected annually (additional $\mathrm{RHI}$ benefits are not included). Although, Wahlroos et al. declared an unclear business model between data center $(\mathrm{DC})$ and district heating $(\mathrm{DH})$ network operators was an essential preventive factor (2018).

Galli, (2018) looked at this matter from an economic point of view, which shows the practicality of waste heat reuse is directly connected to cost. Cost of investment, maintenance fee (especially if a heat pump is in use) should be at least balance out with revenue resulted from energy sold or water domestic heating value. Analysis in a $10 \mathrm{MV}$ DC, showed waste heat utilization through absorption cooling machines, is beneficial as payback time for retrofitting could be 4-5 months. (Ebrahimi et al., 2015)

\subsubsection{Heat Quality Matters!}

Waste heat recovery potentials are directly connected with the type of cooling system being used in the data center. How we can capture excessive heat and optimal location for taking the higher quality heat is another factor affecting the results (Wahlroos et al., 2018). 
According to Table 3, Davies et al. (2016) summarized temperature range of captured heat in aircooled systems would be between $35^{\circ}-45^{\circ} \mathrm{C}$, whereas, $\left(50^{\circ}-60^{\circ} \mathrm{C}\right)$ in liquid-cooled servers. They also clarified by which cooling system application heat recovery would be possible. The explicit Yes/No answers result from the recorded temperature range of different facilities with different cooling systems. In general, liquid cooling is a more promising solution for capturing higher grade heat.

Table 3- Possibilities of waste heat recovery according to the facilities' cooling system (Ref: Davies et al., 2016)

\begin{tabular}{|c|c|c|c|c|}
\hline Cooling system & Cooling medium & Waste heat source & Temperature range $\left({ }^{\circ} \mathrm{C}\right)$ & Recovery possible? \\
\hline \multirow[t]{2}{*}{ Remote air cooling } & Air & Air & $25-35$ & Yes \\
\hline & & Chilled water & $10-20$ & Yes \\
\hline \multirow[t]{2}{*}{ Local air cooling } & Air & Air & $25-35$ & No \\
\hline & & Chilled water & $10-20$ & Yes \\
\hline \multirow[t]{2}{*}{ Hybrid liquid/air cooling } & $30-40 \%$ Air & Air & $25-35$ & Possibly \\
\hline & 60-70\% Liquid & Liquid & $50-60$ & Yes \\
\hline All liquid cooling & Liquid & Liquid & $50-60$ & Yes \\
\hline
\end{tabular}

In order to get the highest heat quality relative to the cooling system in use, collecting location of waste heat would matters. Ebrahimi et al. (2014) pointed out rack exhaust as the optimal points of capturing heat in air-cooled facilities. This location ensures less air mixing and exergy loss as the air passes the room. Waste heat capture is possible at return path to CRAC where the temperature is expected to be between $30^{\circ}$ and $40^{\circ} \mathrm{C}$. In Contrast, Wahlroos et al. (2018) and Davies et al. (2016) claimed heat captured at the same location in air-cooled facilities would be from $25^{\circ} \mathrm{C}$ and $35^{\circ} \mathrm{C}$ and could be carried out by chilled water at $10^{\circ}-20^{\circ} \mathrm{C}$ (lower grade waste heat).

Contrarily, in direct liquid-cooled data centers, waste heat can be captured at $50^{\circ}-60^{\circ} \mathrm{C}$. In this method, coolant is closer to processors (CPU) as the primary heat sources (Wahlroos et al., 2018). Figure 12 indicates the level of heat generation by a range of data center's components. Central processing units (CPUs), constitute of millions of switches with billion times per second on/off action, produce highest degree heat in its vicinity (Beaty \& Quirk, 2017). 


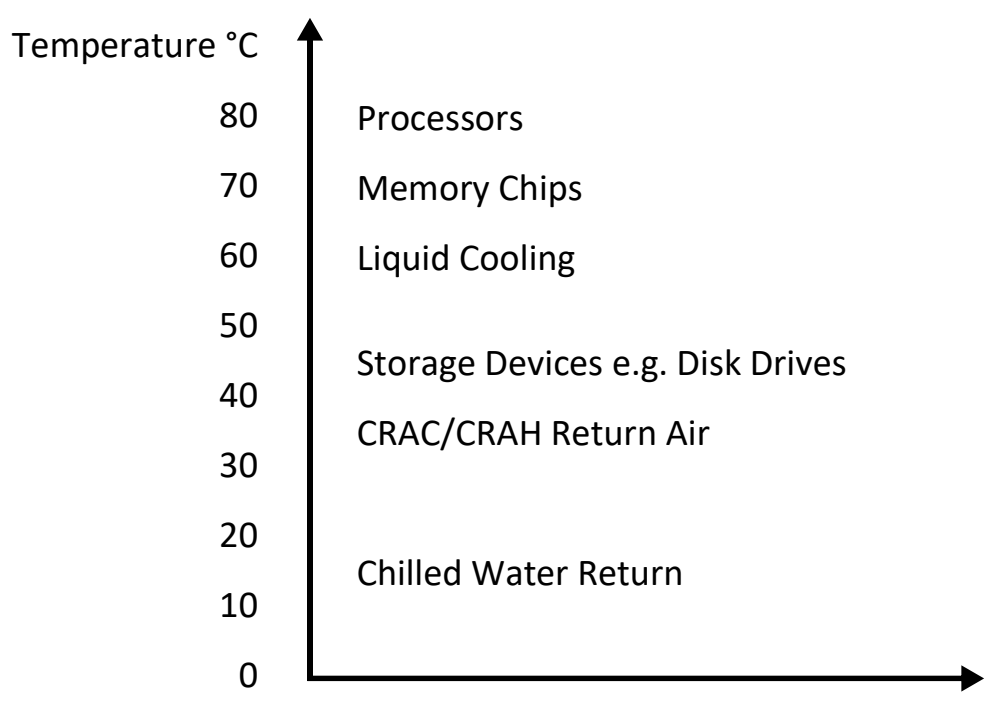

Figure 12- Common temperature range of data centers components (Reproduced from source: Davies et al., 2016)

\subsubsection{Waste Heat Utilization Barriers}

To this point, it is known that, due to significant amount of heat released to the environment by the information and communications technology (ICT) sector, especially data centers worldwide, it is highly vital to identify and implement methods to make use of this valuable energy source in the most efficient way. However, studies showed barriers that hinder or prevent waste heat reuse and recycling. Although, Wahlroos et al. (2018) suggested an 8-step systematic approach to overcome those obstacles. Following is the list of common issues slowing down this process:

- unstable and low-quality heat

- Heat lose its energy in distance

- Investment costs are high

- Data center operators (DC) and district heating operators (DH) have different financial goals

- Unclear business models

- Often the supplementary source of heat is needed

- Information security is critical

Wahlroos et al. (2018) showed the interest of DC operators to reuse waste heat in DH networks. However, lack of transparency between business models of DH network operator and DC operators as well as unavailable real waste heat production and energy consumption of DC 
facilities, prevent making the most out of the available source of heat (technically and economically). Galli (2018) explained that the lack of business model results from the fact that both the DC operator and DH operator as main stakeholders are looking for profits. Initial investments and cost of operation on one side and desire of $\mathrm{DH}$ network stakeholders for cheap, viable, and stable source of energy on the other side, led to an unclear path for data centers. Therefore, there is not a fine line in this trade, where several unclear parameters are involved.

It is evident that there are more non-technical barriers in which, low-quality waste heat and high investment cost are noted as the most important among all (Wahlroos et al., 2018). Readiness for accepting new cooling technologies, cost viability from heat sale, and the influence of carbon and energy saving on status quo are other non-technical barriers mentioned by (Davies et al., 2016) and subjected for future studies.

\subsubsection{Waste Heat Recovery Technologies}

The following section provides an overview of heat recovery technologies with potential applications in data centers. According to Ebrahimi et al. (2014) and Wahlroos et al. (2018), a range of possible reuse applications for data center waste heat is collected in Table 4. Following techniques are among the most commonly used strategies and studies relevant to the scope of this study.

Table 4 Waste heat utilization application (Ref: (Wahlroos et al., 2018) \& (Ebrahimi et al., 2014))

\begin{aligned} On-site Consumption & External Use \\ \hline Space Heating & Drying biomass \\ Floor Heating & power plant water preheating \\ Domestic Hot Water & District heating \\ Melting Snow & water desalination \\ Absorption cooling & Organic Rankine cycles \\ & Piezoelectrics \\ & Thermoelectrics \end{aligned}




\section{Domestic Space and Water Heating:}

A typical air-cooled data center can provide waste heat range from $30^{\circ}$ to $40^{\circ} \mathrm{C}$. Which can be used directly at adjacent spaces (where available) or making use of it in water heating/ preheating as per demand (Davies et al., 2016).

When data center waste heat is likely to capture efficiently, the best and ideal solution is utilizing it in direct heating, which would be the simplest solution if low-temperature heating is required (Galli, 2018). In 2019, Deymi-Dashtebayaz \& Valipour-Namanlo calculated about \$25k saving per annum resulted from the reuse of data center's waste heat in domestic heating of neighbouring buildings, with the integration of an air source heat pump in the system. Marcinichen et al. (2012, cited by (Wahlroos et al., 2018), p.1750) showed data center's low-temperature waste heat could be used in preheating the water in power plant, and led to almost $2.2 \%$ energy saving and improvement of efficiency.

\section{District Heating Network:}

District heating network representing a great advantage, as it allows renewable strategies and waste heat recovery systems as additional heat sources in the system (Galli, 2018). (Figure 13)
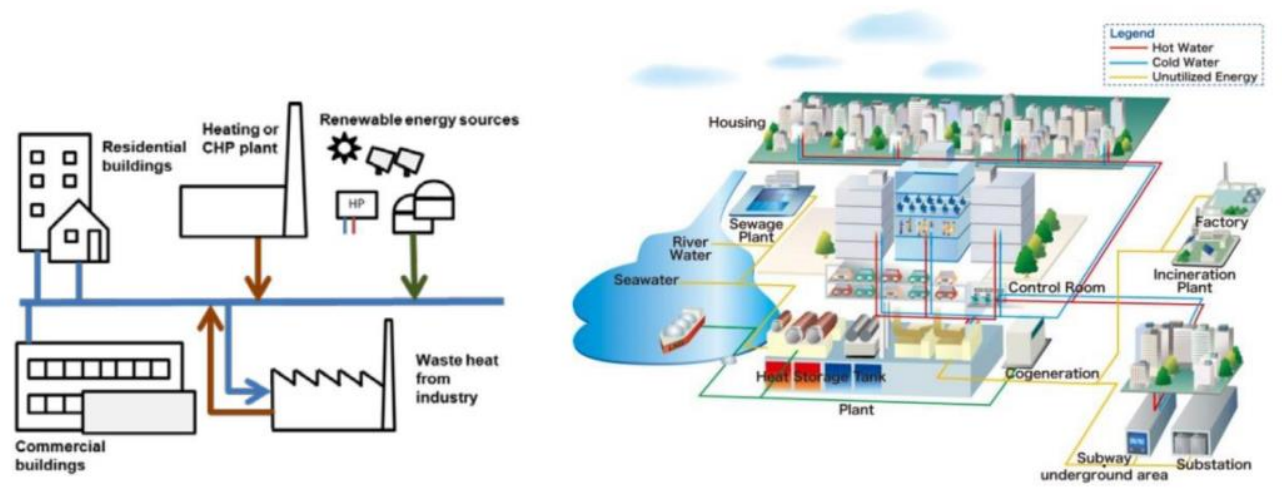

Figure 13-"District Heating Chain" presented by (Galli, 2018)

In most cases considering this recovery method, data centers are built as stand-alone structures without many neighbouring buildings. Also, with respect to larger scale DC facilities, which can provide a year-round heat source, domestic heating (only winters) is not the best method. DH networks have steadier heat demand but with higher grade heat requirement, where heat pumps need to be used (Davies et al., 2016). 
Typically, natural gas, fossil fuel, biomass and waste to energy treatments are used to power the cogenerative thermoelectric power plant to produce heat in district heating network. In recent years, renewable sources (e.g. geothermal, solar heating, etc.) and free waste heat recovery from industrial and data centers have been integrated into the networks and known as heat sources with high efficiencies and environmentally friendlier power production sources.

The emergence of decentralizing heat production for every single building led to a fewer number of boilers, less resulting boiler related risks, and neglecting average 10-30\% thermal loss (Galli, 2018) (Kofinger et al., 2016).

Davies et al. (2016) evaluated the potential application of waste heat recovery and reused in district heating network in the UK. This study evaluated possible carbon and energy savings potential from the reuse of heat in district heating network in several selected London districts. Prior to this point, captured heat from DCs, especially those equipped with air-cooled systems, typically need extra efforts to meet $\mathrm{DH}$ requirements. Heat pumps are utilized at this point. Heat

pumps are responsible for boosting the temperature of captured waste heat before transferring to DH networks.

According to recorded London districts heat demand and potential heat recovered from DCs results indicated more than $50 \%$ of heat demand in Tower Helmet district could be provided. Where in other districts, less than $10 \%$ of the total load can be met. All proved the importance and values of the proposed source of heat in the future (Davies et al., 2016).

A small size data center with applied primary heat recovery system has been investigated.

Primarily, this DCs waste heat being used through domestic space heating and water heating of a building in the immediate vicinity. Further investigation for the feasibility of utilizing the heat in the $\mathrm{DH}$ network is the focus of the study. With four different scenarios, focused on comparison according to investment cost, operating cost and primary energy consumption, results showed in one scenario $20-50 \%$ reduction in the cost of energy (kwh). Energy is used for building heating through a district heating network. (Galli, 2018)

\section{Low-Temperature District Heating (LTDH):}

New construction technologies and proposed rating systems ambitiously, are working hard to move building performance baseline somewhat closer to net-zero energy. Visioning it more realistically, nowadays, rated new constructions and retrofitted buildings are consuming less energy than before. If the industry moves on the same path, more efficient buildings with less energy demand would be expected. Low Temperature District Heating network is four district 
heating generation, to power those houses with lower temperature heat (i.e. supply and return temperature of $50^{\circ} \mathrm{C}$ and $30^{\circ} \mathrm{C}$ respectively) (Galli, 2018). Thanks to this heating network, lowgrade DC heat can be used directly, without heat pumps, in LTDH networks broadly in the near future. Galli claimed LTDH as a valuable solution if coupled with low-temperature heating systems (2018).

\section{Absorption Chillers:}

In this system, waste heat contributes to the cooling process. In order to direct use of DC waste heat in absorption refrigeration process, $70-90^{\circ} \mathrm{C}$ temperature is required (Davies et al., 2016). Ebrahimi et al. (2015) continued and updated the series of researches had been done by Kim et al. (2012, cited by (Ebrahimi et al., 2015) p.385) on different configurations of absorption refrigeration system applied in data centers. Ebrahimi et al. (2015) declared absorption refrigeration system as a promising and economically feasible solution for future of data center waste heat and proved this statement by a detailed steady-state thermodynamic model over a data center. Model development and validation were over a utilized liquid/ on-chip two-phase cooled Data center coupled with absorption refrigeration system, where condenser was replaced by cooling generator. Results indicated that waste heat recovery by this configuration enables cooling of an other server rack when dissipated heat from 3 to 5 racks was collected and utilized by the absorption refrigeration system. Also, through economic analysis, the payback period for this system is as short as $4-5$ months. 


\subsection{Case Study: Earth Rangers}

\subsection{Objective of Case Study}

This study has been based on data collected from Earth Rangers Center documentation and recordings collected from live metering sensors. Primarily, the objective of this research study is the development of the model of ERC's data center for future series of studies planned accordingly. Facility manager's tendency to evaluate ideas and opportunities in order to reduce cooling energy consumption is the willpower for this research. Clearly, experimental evaluation of their facility would costs significantly more than when the assessment process done by virtual energy model. A reliable energy model requires to be validated and calibration to the real data. This study aims to evaluate and propose methods of developing a valid energy model for the data center. Meanwhile, an alternative configuration of HVAC design is proposed and evaluated to establish a better understanding of potentials in this case study.

High level of data security and store information in data centers explain the value behind them. Unfortunately, the lack of available research studies around this idea hinders the progress of similar research ideas between researchers. This study aims to take steps towards facilitating future performance evaluation in ERC's data center and similar research projects.

\subsection{Data Collection}

Essential information has been collected from the website, site visits, interviews, and building documentation.

A couple of site visits have been completed. First, a walk-through assessment has been done, and the required notes have been taken and documented. From the second site visit through the final days, several interviews, data collection from their energy metering platform, and physical construction drawings were collected. Related collected information is categorized and provided in the following sections.

$\mathrm{ERC}$ is controlled through a central control interface to the automation system. It is equipped with an energy metering system called, PowerLogic ION Enterprise, that monitors electricity, gas and water usage real time. Data has been stored in 15-minute increments since August of 2009 (Our Facility - Earth Rangers, 2013). Noting that, these data sets are about the whole building and not separated for data center, as data center was not initially part of the construction plan. 


\section{Earth Rangers Centre}

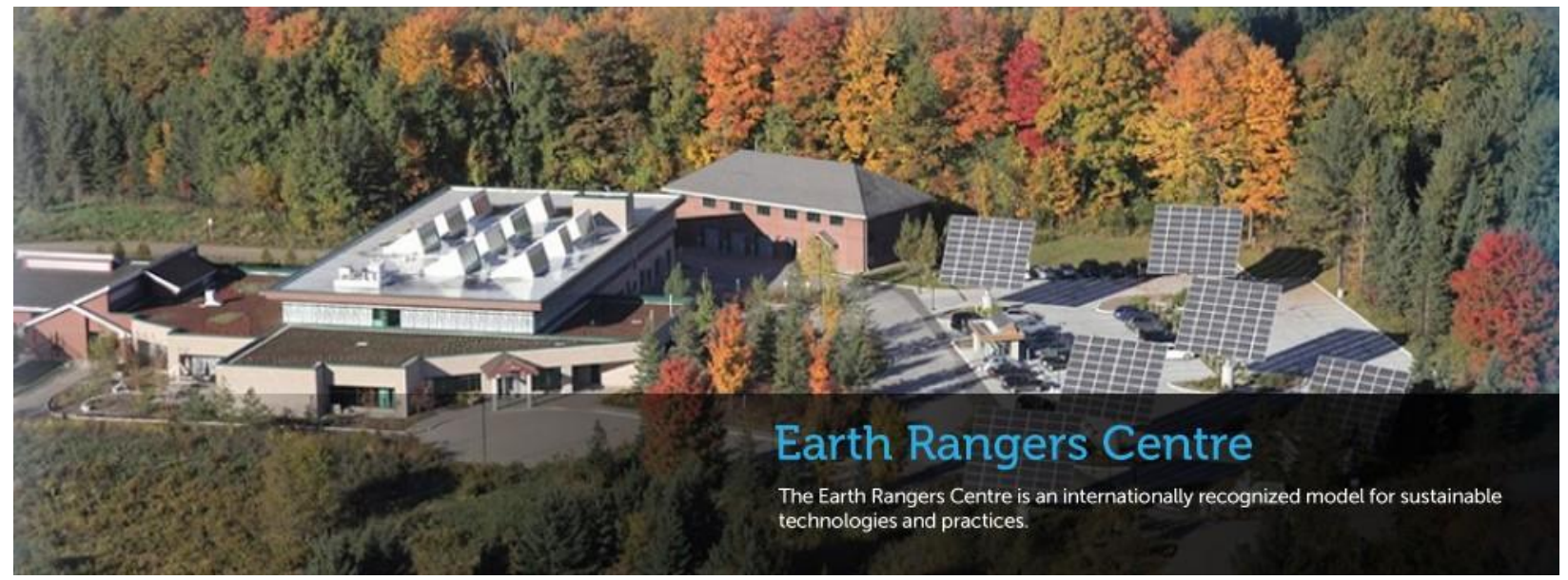

Figure 14 Image retrieved from Our Facility - Earth Rangers. (2013) [www.ercshowcase.com]

\subsection{About ERC}

Earth Rangers is a non-profit organization located Woodbridge, Ontario, Canada, with about 190,000 members in every province and territory. Earth Rangers committed to educate and inspire children to protect biodiversity and bring back the wild. Their goal is creating a new generation of environmental conservationists.

Earth Rangers Centre (ERC) is the home to the animal ambassadors and staff. The building is a showcase of state-of-the-art technologies with sustainability approaches. "The Centre was designed to embody Earth Rangers' values, showing that we practice what we preach, and inspiring everyone who walks through our doors." (Our Facility - Earth Rangers, 2013)

Earth Rangers as an advanced green building encompasses all following strategies: building automation strategies, energy metering, waste \& water management, solar thermal \& solar PVs, green roofs, and geothermal. It possesses Gold LEED in new construction category and Platinum LEED for existing buildings: operation and maintenance (92 scores out of 100). ERC's energy consumption is reported almost $90 \%$ less than other similar buildings of the same size (Our Facility - Earth Rangers, 2013). 


\section{Building Integration:}

Integration includes a standard control interface that connects all building systems that performs individually. This eliminates any conflict between different systems and enable

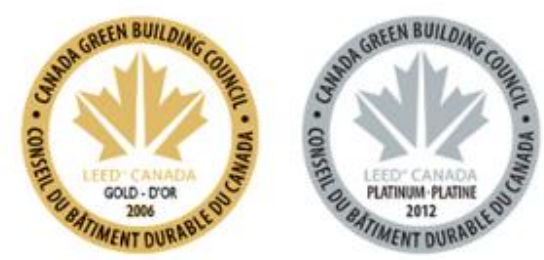
them working cooperatively. Subsystems in ERC comprises of building automation, power metering, security and lighting. The integration enables the building to operate at peak efficiency and engage only necessary systems at any given time. Areas of concern and opportunities for system improvement and optimization can be identified conveniently by this system.

Lighting in ERC has reduced by $50 \%$ by the integration of first natural daylighting, skylights and then, low mercury fluorescent or LED fixtures where needed. Lighting in all occupied areas is controlled by sensors managed by BACnet controllers interconnected to the building automation system.

In Data Center room Juno LED track lights are used. They are determined as task lighting for more convenience in maintenance, with a minimum amount of heat production in the room.

Power metering provides the total picture of how the building operates. How much gas, thermal energy and water is being consumed. Eighty different subsystems are being tracked in ERC by Schneider Electric's ION Enterprise to identify potential conservation areas.

Building Automation is what brain and muscle are to the body (Building). The Andover Continuum Building Automation system controls lighting, HVAC and access control systems by thousands of separate sensors. Improving energy use while ensuring internal occupancy comfort levels and air quality. 


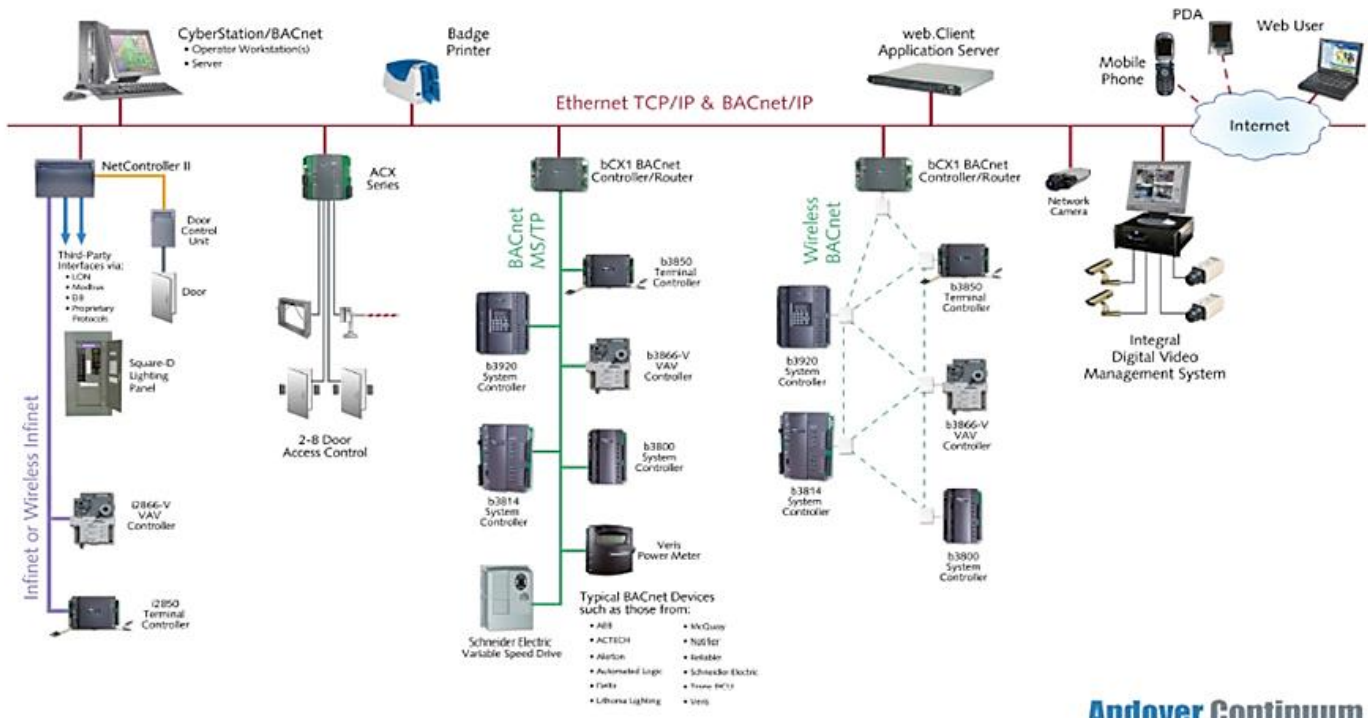

Figure 15 Schematic graph illustrates the Andover Continuum automation system combines different systems in an integrated platform. (Image source: Our Facility - Earth Rangers, www.ercshowcase.com, 2013)

Renewables on site are there to fulfill the goal of generating energy as much as it consumes in ERC. Both conservation and on-site generations assist in accomplishing this target. A third of electricity consumes in ERC is generated by photovoltaic modules (324 modules at parking lot trackers and 144 modules at roof arrays). Estimating the total power generation is $113,800 \mathrm{kWh}$ annually. In addition to PV modules, solar thermal water heaters are being used for harvesting energy.

Renewables off-site is referring to the rest of the power used in ERC that comes from wind power or low-impact hydroelectric (EcoLogo certified). 


\section{ERC Energy Consumption Breakdown}

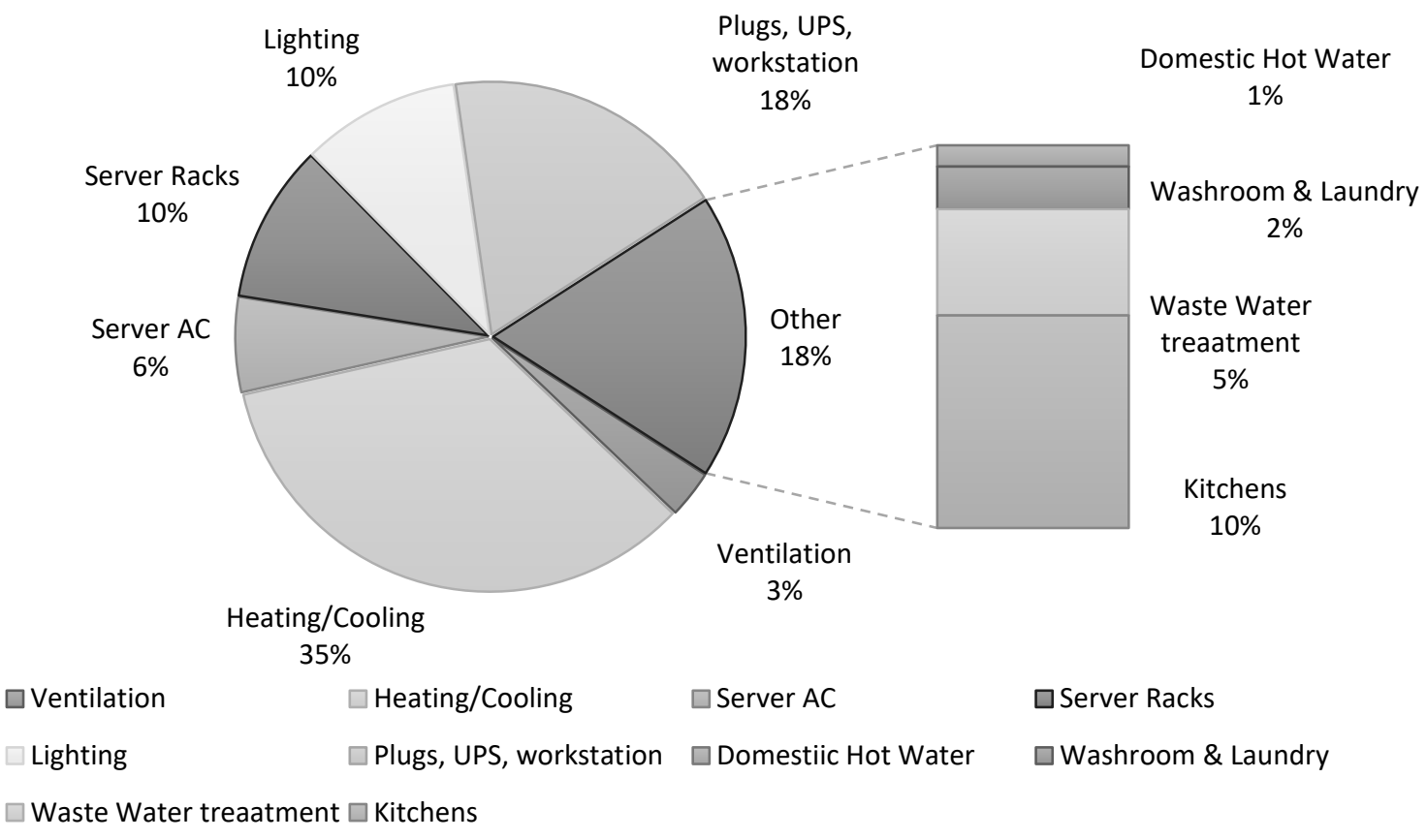

Figure 16 Total energy consumption breakdown of Earth Rangers Center (Ref: Our Facility - Earth Rangers,2013) 


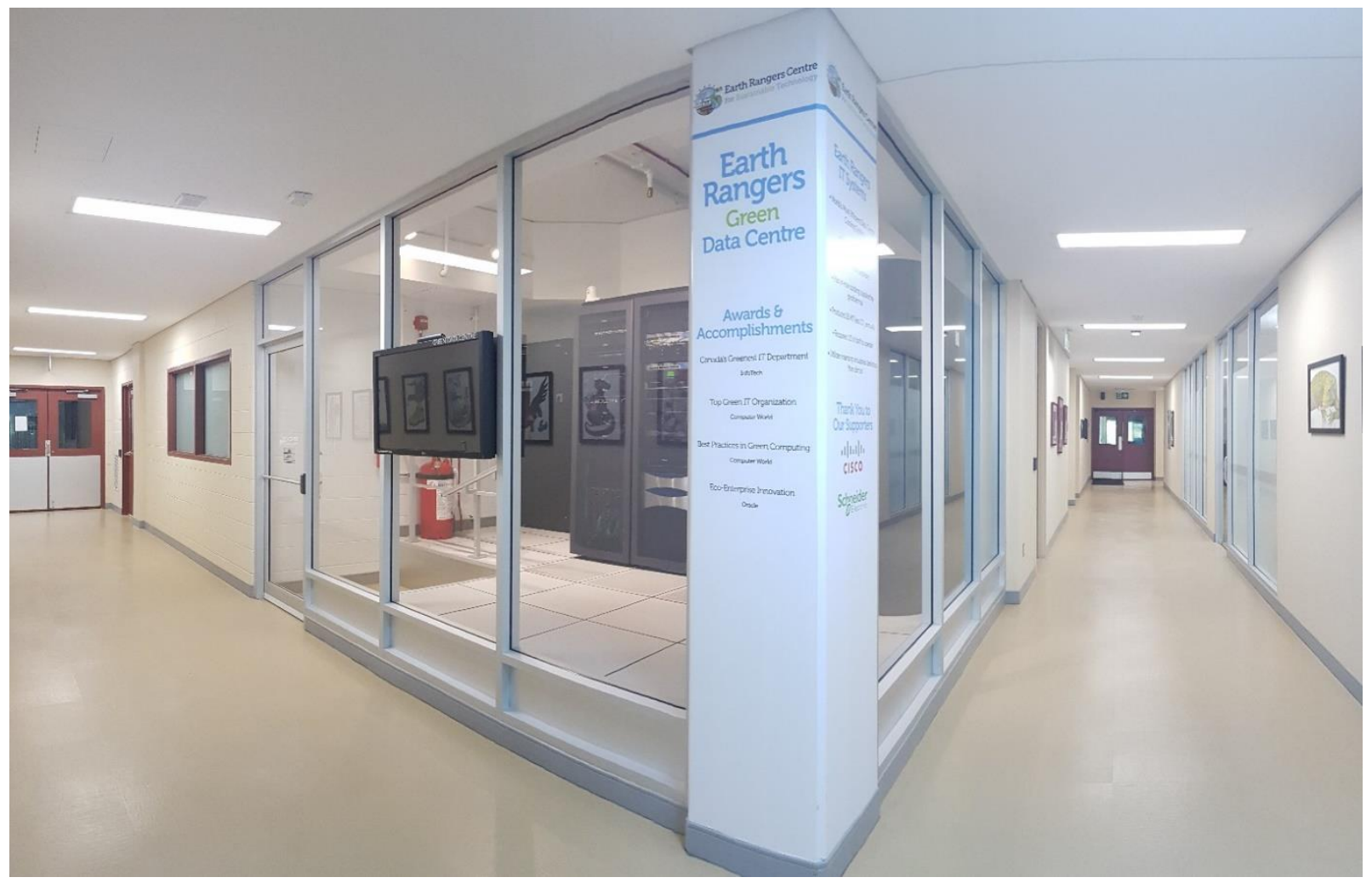

Figure 17 Earth Rangers' Data Center panoramic view (Photo credit: Ladan Arbabi)

\subsection{The Data Center}

The data center is the house of computer servers, hard drives for storing data and back-up purposes, networking infrastructure, security and cooling system. ERC's performance encompasses housing email systems, web pages, phone and other modern communication infrastructures in addition to building automation system data processing. It housed an office support system and kept data secure.

ERC's data center is only $16 \mathrm{~m}^{2}$ ( $\left.173 \mathrm{ft}^{2}\right)$. In 2012 , it reported that $12 \%$ of total energy consumption of the building belongs to the DC (This figure does not include office components). This data center combines powerful processing capacity with efficient technology which leads to energy consumption reduction and cost in the whole facility performance. ERC's data center is built for several reasons. Data center eliminated the presence of many computer servers scattered throughout the building performing with low capacity. Instead many computers run in a virtual environment. In 2012, 22 virtual computers were run on one single blade server. This led to less occupied space, the high capacity performance of the server and lower the cooling load. 


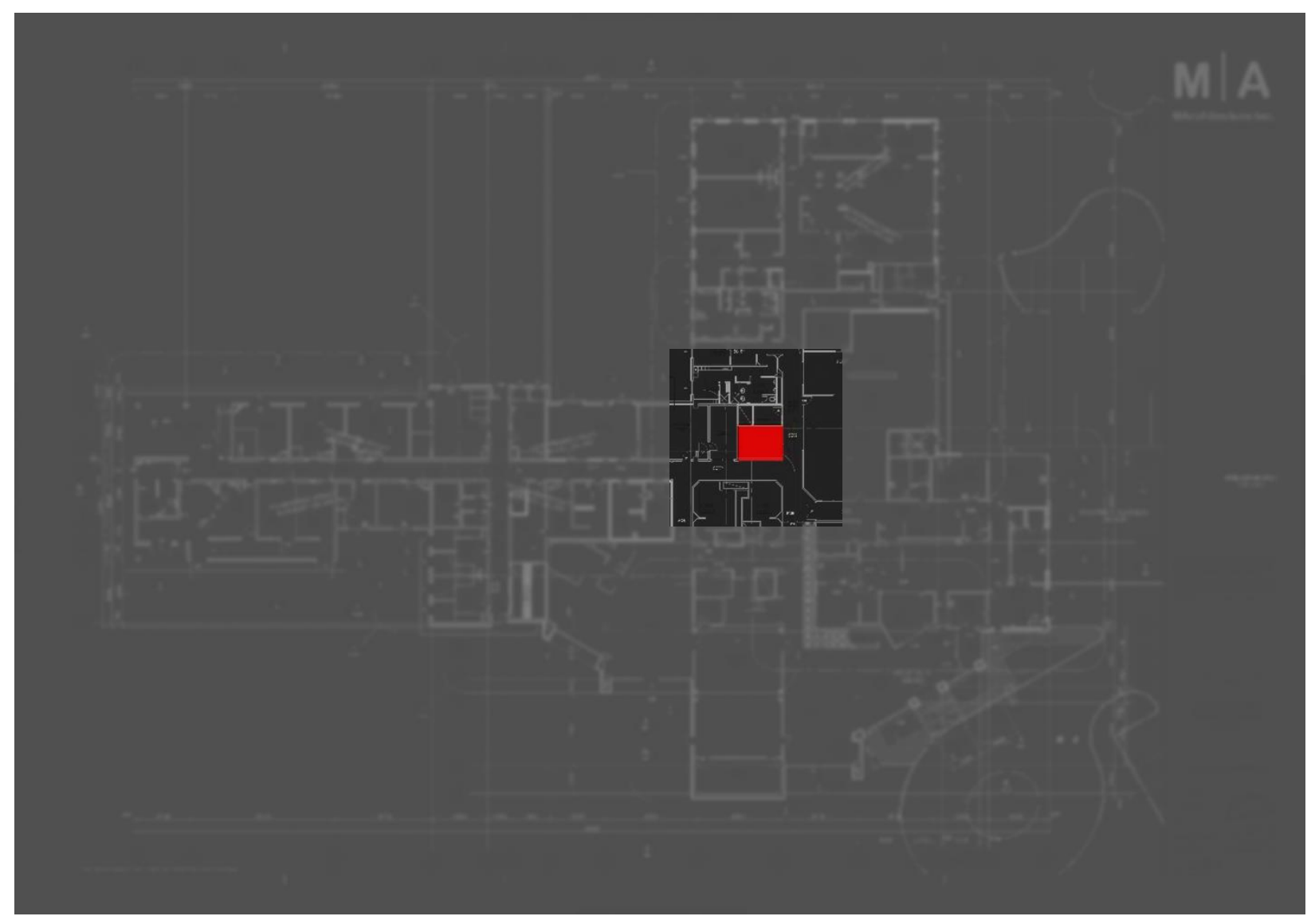

Figure 18 ground Floor Plan - ERC (Image is blured due to privacy reasons)

The data center occupies a small area in the core of Earth Rangers Center with dimensions of $3.55 \mathrm{~m} \times 3.5 \mathrm{~m} \times 4.6 \mathrm{~m}\left(11^{\prime} 7^{\prime \prime} \times 11^{\prime} 6^{\prime \prime} \times 15^{\prime} 1^{\prime \prime}\right)$. All equipment including, server blades, storage arrays, security and networking blades, switches and power supplies are placed in one row of rack cabinets. (Figure 19)

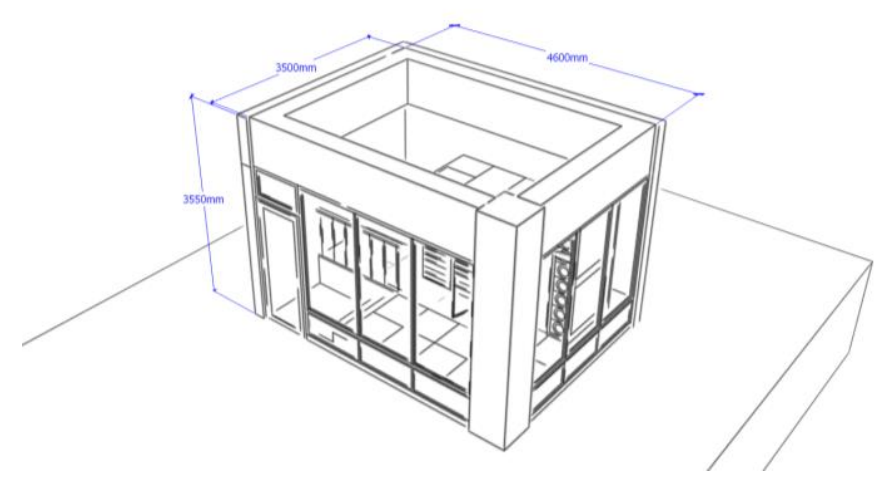

Figure 19 Three- dimensional sketch and measurements of the data center 
There is an in-row cooling unit at the end of the row (Figure 20). The data center is built on a 2foot raised floor plenum with designated perforated tile which is no longer in use (except when back-up cooling becomes crucial). The data center was initially designed to be cooled by the CRAC unit. However, currently, the CRAC unit is only considered as a back-up cooling and chilled water in-row cooling unit is installed instead.

The data center 's configuration adapted the current best practice of hot and cold aisles arrangement. The server racks are placed in such a way that cold air enters the racks from the front side (cold aisle) and leave them with higher temperature from the back side (hot aisle). Cold air is used to delivers to the room from floor perforated tiles, but now it delivers horizontally from side unit (in-row unit).

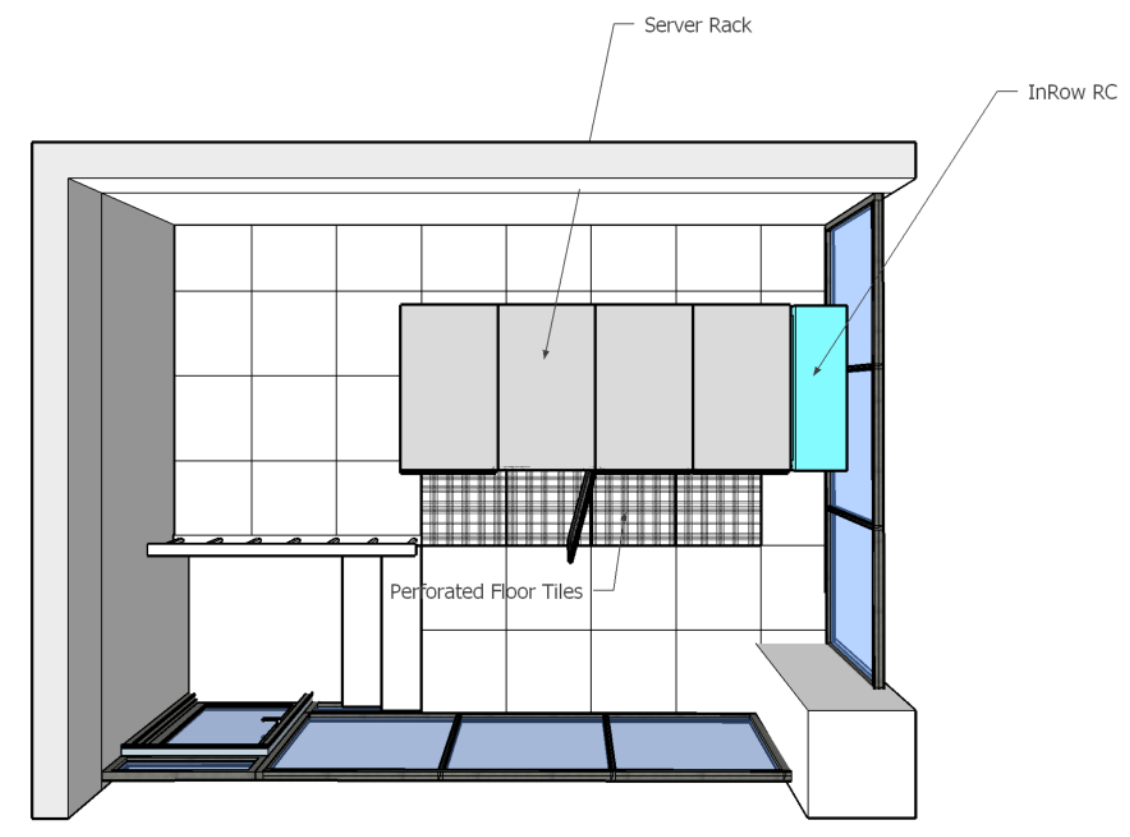

Figure 20 Earth Rangers data center - Plan view 


\subsubsection{Information Technology Equipment}

During the site visits, the name of equipment being used in the data centers is collected.

Relevant features of every piece are collected from associated spec sheets and summarized on the following tables.

Table 5 \& Table 6, listed a brief description of components available in each rack and their quantities. Table 5, presented the main Rack's components in a detailed manner. Main Rack is the closest to the cooling system contains server blades, storage arrays and Networking. Noting that, the server rack is deliberately placed closest to the airflow outlet. This helps cooling become more efficient and targeted. (Refer to Figure 20)

Table 5 Earth Rangers' rack No. 1 components

\begin{tabular}{|c|c|c|c|}
\hline \multicolumn{2}{|r|}{ DC's main Rack } & Quantity & Description. \\
\hline \multirow[b]{2}{*}{ 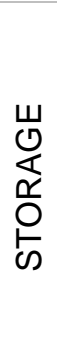 } & Pillar Axiom Pilot & 8 & \multirow[b]{2}{*}{$\begin{array}{l}\text { An Application-Aware storage }{ }^{\mathrm{TM}} \text { system. This feature enables } \\
\text { dynamic adjustment in performance of the storage system relative } \\
\text { to the requirement of applications. Storage utilization is expected } \\
\text { to enlarge due to performance prediction ability. } \\
\text { An external interface to the host storage network is provided by } \\
\text { the slammer. } \\
\text { Pilar axiom system supports one to four slammers. } \\
\text { (Ref: Pilar Axiom-System Architecture Overview) }\end{array}$} \\
\hline & $\begin{array}{l}\text { Pillar Axiom } \\
\text { Slammer }\end{array}$ & 1 & \\
\hline 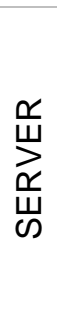 & $\begin{array}{l}\text { Cisco UCS } 5108 \\
\text { Blade Server } \\
\text { Chassis PSU }\end{array}$ & 1 & $\begin{array}{l}6 \text { Rack Unit }(6 \mathrm{U}) \\
\text { Eight half-width slots, four full-width slots } \\
\text { Operating Temperature } 10^{\circ} \mathrm{C} \text { to } 35^{\circ} \mathrm{C}\left(50^{\circ} \mathrm{F} \text { to } 95^{\circ} \mathrm{F}\right) \\
\text { Max. output power per power supply }-2500 \mathrm{~W} \text { (up to } 4 \text { supplies) } \\
\text { Max. heat output }-8530 \mathrm{BTU} \\
\text { Efficiency - } 88 \% \text { at } 10-20 \% \& 100 \% \text { Load, } 92 \% \text { at } 50 \% \text { Load } \\
\text { (Ref: Cisco UCS } 5108 \text { Blade Server Chassis - Spec Sheet) }\end{array}$ \\
\hline 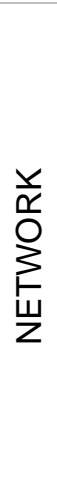 & $\begin{array}{l}\text { Cisco UCS } \\
\text { 6248UP PSU }\end{array}$ & 2 & $\begin{array}{l}\text { one-rack-unit (1RU) 10-Gigabit Ethernet } \\
\text { 48-port Fabric Interconnect (consumes less power per port than } \\
\text { traditional systems) } \\
\text { - Cisco Unified Computing System (UCS), provides network } \\
\text { connectivity and management capabilities for the system. } \\
\text { - Provided management and communication backbone for the } \\
\text { servers. } \\
\text { Minimum Output Power - } 750 \mathrm{~W} \\
\text { Heat dissipation } 2497 \mathrm{BTU} / \mathrm{hr} \text { ( } 732 \mathrm{~W} \text { ) } \\
\text { Efficiency } 88 \text { to } 92 \% \text { (50 to } 100 \% \text { load) } \\
\text { (Ref: Cisco UCS } 6200 \text { Series Fabric Interconnect - Spec Sheet) }\end{array}$ \\
\hline
\end{tabular}


Table 6 covers other rack's components. Collected data is combined from site visits and recorded data from building automation systems or assumptions made with the consultancy of ERC's facility manager.

Table 6 Earth Rangers' other racks' active components

\begin{tabular}{|c|c|c|}
\hline DC's Rack (others) & Quantity & Description. \\
\hline $\begin{array}{l}\text { Cisco S170 } \\
\text { Web Security } \\
\text { Appliance }\end{array}$ & 1 & $\begin{array}{l}\text { Organizer and traffic control } \\
\text { Rack height: } 1 \text { RU } \\
\text { Temperature allowance: } 104 \text { F ( } 40 \text { C) } \\
\text { (Ref: Cisco S170 Web Security Appliance-Specification Sheet) }\end{array}$ \\
\hline $\begin{array}{l}\text { Cisco } 2911 \\
\text { Integrated Services } \\
\text { Router (ISR) }\end{array}$ & 1 & $\begin{array}{l}\text { Rack height: } 2 R U \\
\text { Delivering data, voice, video, and application service with a high } \\
\text { security level }\end{array}$ \\
\hline Miscellaneous & 1 & Including other servers, switches, power supplies, etc. \\
\hline
\end{tabular}

Referring to Table 7 , total heat dissipation by all racks calculated $8.7 \mathrm{~kW}$. This number refers to the $100 \%$ load of servers and includes all power usage rate of server, storage and networking components. The load density index of IT equipment is calculated slightly over $554 \mathrm{~W} / \mathrm{m}^{2}(50$ $\left.\mathrm{W} / \mathrm{ft}^{2}\right)$.

Table 7 Racks heat dissipation breakdown

\begin{tabular}{llll}
\hline \multicolumn{1}{c}{ Data Center's Equipment } & No. & $\begin{array}{l}\text { Heat dissipation } \\
(\mathbf{W})-\text { each }\end{array}$ & $\begin{array}{l}\text { Heat dissipation (W) - } \\
\text { Total }\end{array}$ \\
\hline Pillar Axiom Pilot & 8 & 109 & 872 \\
\hline Pillar Axiom Slammer & 1 & 592 & 592 \\
\hline $\begin{array}{l}\text { Cisco UCS 5108 Blade Server Chassis } \\
\text { PSU }\end{array}$ & 1 & 2498 & 2498 \\
\hline Cisco UCS 6248UP PSU & 2 & 732 & 1464 \\
\hline Cisco S170 & 1 & 127 & 127 \\
\hline Cisco 2911 & 1 & 210 & 210 \\
\hline Miscellaneous & 1 & 2930 & 2930 \\
\hline
\end{tabular}




\subsubsection{Cooling System}

Earth Rangers is a large facility that contains a very small data center in its center (Figure 18). According to the scope of this research, any given information in subsequent sections is majorly concentrated on data center and associated components.

Focusing on the data center, server racks are the major contributors to heat generation in the room. Room air is conditioned by chilled water In-Row RC equipment. Its coolant is cooled by the geothermal system for the majority of the year and claimed only some days in summer chiller is used as a backup.

IN-Row Rack Cooling (RC) unit supplies air at on average $16 \mathrm{C}$. for achieving setpoint of $18 \mathrm{C}$.

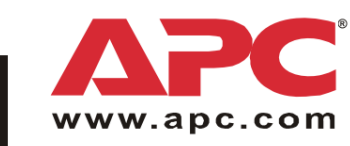

APC - ACRC100 manufactured by Schneider Electric is a chilled water modular air conditioning unit inside the DC room. The Unit is the American Power Conversion (APC ${ }^{\mathrm{TM}}$ ) In-Row RC from ACRC100 series. This series is available in a half-rack model $(300 \mathrm{~mm})$, with the same standard enclosure width. Features of the In-Row RC are as follows: Full management capabilities over a network, temperature and output contact monitoring, group control, remote shutdown, accessible by various networks and browsers (Telnet, FTP, SSH, SCP, serial connection, the display interface), Email notifications, security protocols, and access to Syslog events.

IN-Row is one among four configurations (RACS, HACS, CACS, and In-Row) that applies when the airflow is horizontal. Row-based systems like APC - ACRC100 series are placed in line with rack enclosures. At least one system is required per hot aisle. In this system, the air is drawn in through the rear door (hot aisle), it gets cooled by passing through chilled water loops and then it is discharged into the cold aisle. In order to eliminate hot spots, The In-Row RC delivers high volumes of airflow into the cold aisle. Two sizes are available in the In-Row RC chilled water configuration with a capacity of up to $70 \mathrm{~kW}$ based on the unit's application (In-Row RC $50 / 60 \mathrm{~Hz}$ Technical Data Manual, Technical Data).

In In-Row RC units, the active status of cooling unit properties is available and accessible through its web-base browser. Table 8 shows the live status of In-Row cooling unit on Jan $30^{\text {th }}$, 2019 during the site visit. 
Table 8 In-Row RC status on Jan 30th, 2019

\begin{tabular}{|l|l|}
\hline Cool Setpoint & $18^{\circ} \mathrm{C}$ \\
\hline Rack Inlet temp & $23.9^{\circ} \mathrm{C}$ \\
\hline Supply Air Temperature & $17.7^{\circ} \mathrm{C}$ \\
\hline Return Air Temperature & $23.2^{\circ} \mathrm{C}$ \\
\hline Airflow & $2265 \mathrm{CFM}$ \\
\hline Fan speed & $72 \%$ \\
\hline Cool Output & $7.6 \mathrm{kw}$ \\
\hline Cool Demand & $10.6 \mathrm{kw}$ \\
\hline Unit Energy & $9041 \mathrm{kwh}$ \\
\hline Unit Power & $379 \mathrm{w}$ \\
\hline Chilled Water Flow & $40 \mathrm{~L} / \mathrm{m}$ \\
\hline Entering Chilled Water Temperature & $12.6^{\circ} \mathrm{C}$ \\
\hline Leaving chilled Water Temperature & $15.4{ }^{\circ} \mathrm{C}$ \\
\hline Filter Differential Pressure & $12.45 \mathrm{~Pa}$ \\
\hline
\end{tabular}

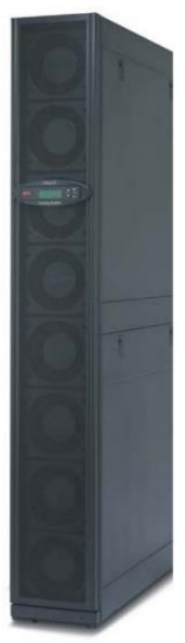

Figure 21 In-Row RC- ACRC100 $50 / 60 \mathrm{~Hz}-100-120 \mathrm{v}$ 


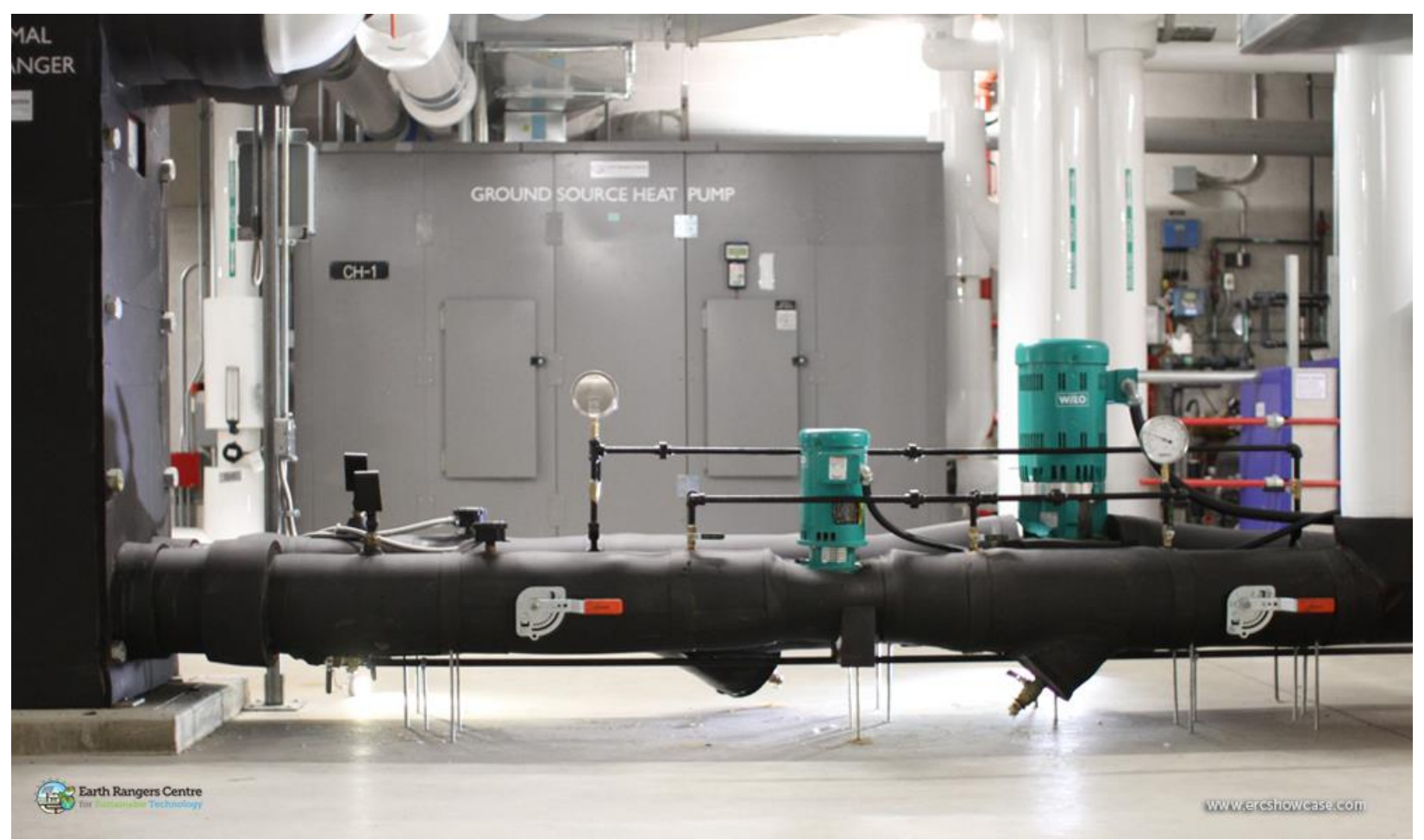

Figure 22 Ground Source Heat Pump \& Heat exchanger (Ref: Our Facility - Earth Rangers. (2013))

\section{Geothermal System:}

The sun Keeps the Geothermal heat pump (GHP) is an efficient and environmentally friendly technology which relies on circulating water through pipes placed underground (either vertically or horizontally) to tap the natural heat retained by the earth. The ground temperature typically remains at a relatively stable degree year-round.

Buried pipes perform as a heat exchanger that transfers energy to a mechanical refrigeration equipment component in order to boost this energy for further uses (Figure 23). The whole

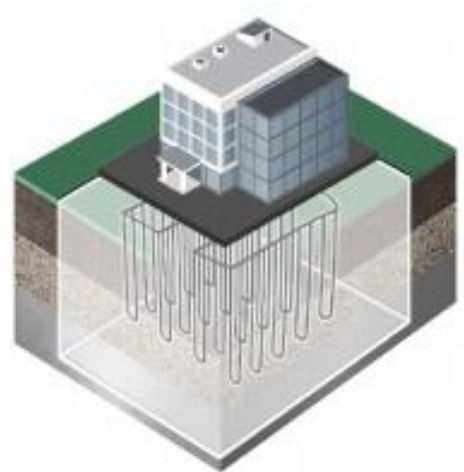

Figure 23 Illustration of Geothermal boreholes in the ground (Ref: www.ercshowcase.com) system cooperatively performs to achieve the right quality building comfort level.

Ground source heat pump systems are the future technology for saving more energy. Geothermal energy resources comprise three categories according to the ground temperature. GSHP is one that applies where the ground temperature is less than $32 \mathrm{C}$. 
GSHP replaced $90 \%$ of total gas consumption in ERC since GSHP is Three times as efficient as using boilers. There has been a $40 \%$ carbon footprint reduction as a result.

Earth Rangers centre' geothermal system has 44 borehole wells with at least 120 meters depth. They were drilled underneath the parking lot during while building construction was in process. ERC's building automation system tracks temperature, pressure and volumetric flow of pumps in a geothermal system.

The graph below illustrates a comparison between daily temperature recording of output fluid of geothermal pipes (considered as mean ground temperature) and outdoor air temperature in 2018. The stable ground temperature throughout the year helps to eliminate extra preheating in winter time and pre-cooling in summer although recorded ground summer temperature is slightly higher than the desired temperature for cooling application of the data center.

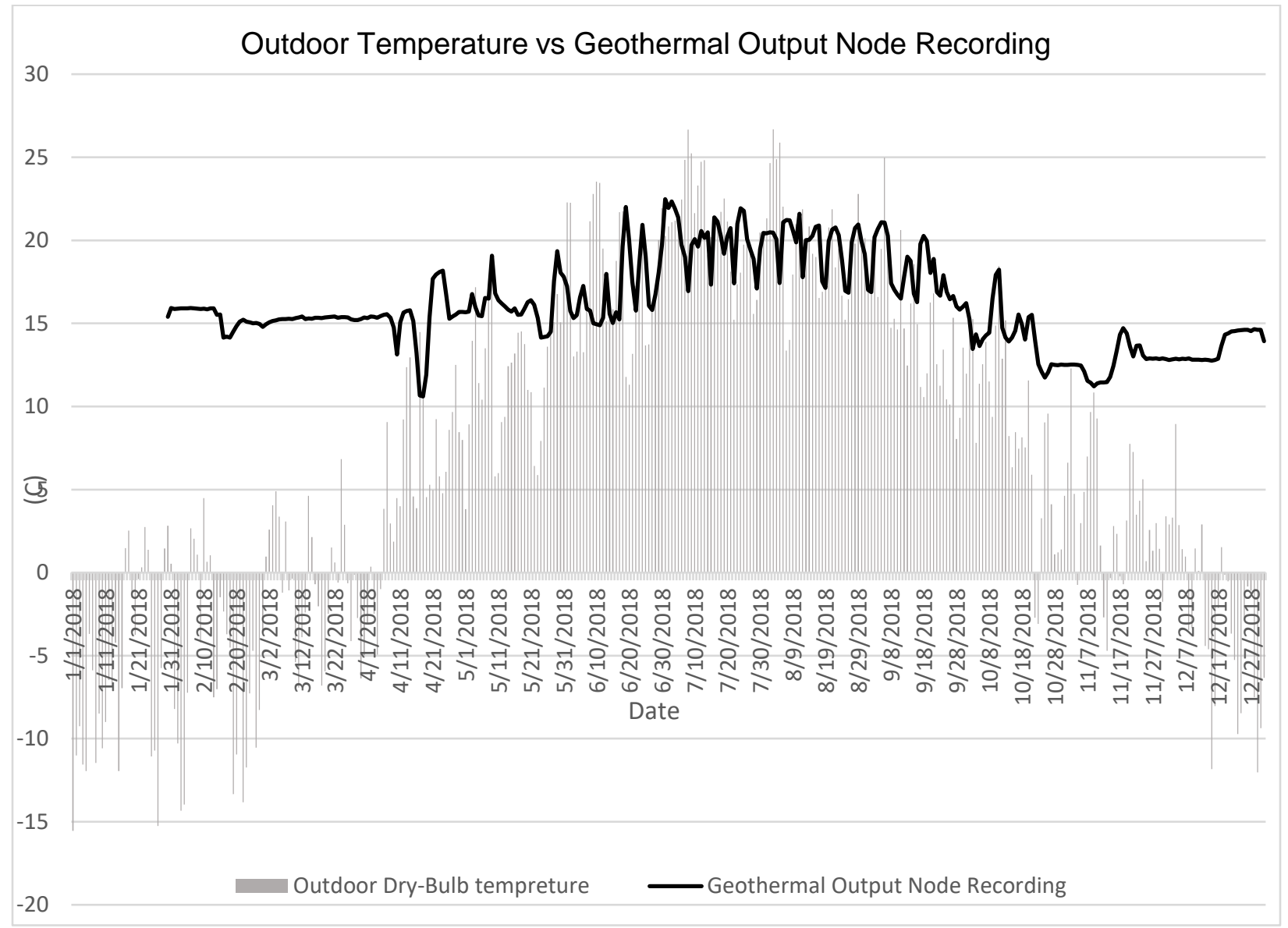

Figure 24 Recorded daily temperature of outdoor air vs. geothermal output node recording, 2018 


\subsection{Methodology}

Majority of data centers acquire a high level of security, which does not allow any access to non-members. Even though data center facilities are always under the supervision of professionals and mostly equipped with data monitoring systems for maintenance and control, those data cannot be found and accessed easily. As mentioned, this research is a case study based upon a real site. Even though the data center counts as a small size DC, but developing a virtual model of such building types helps to identify advantageous future modifications This chapter starts with the choice of energy simulating software as the heart of the research. The software was chosen based on its capabilities, the strength of its outputs and variance input range. In order to achieve the research objective. The data center is modelled and modified based on available recorded data and assumptions. Then, resulted values from the software were compared and analyzed with real data. It is expected that results encounter some dissimilarities due to the complexity of data center performance and ongoing changes on server loads. At the next stage adjustments required for model calibration. Practical methods are identified and investigated in order to achieve similar performance trend comparing to the actual data.

During this study, two more HVAC configuration was analyzed and compared to current design for active assistance to the facility manager to better understand and distinguish their options for future expansions. It also helped to make a better comparison of different scenarios with available equipment that would happen in Earth Rangers.

\subsection{DesignBuilder: The Simulation Software}

DesignBuilder is an elegant and easy to use Graphical User Interface for EnergyPlus as a dynamic thermal simulation engine. DesignBuilder is generally used for calculation energy performance of buildings. It enables users modelling complex buildings in a simple, fast way. DesignBuilder, with its unique ease of use, combines 3D building modelling with dynamic energy simulations. User can compare alternative building designs by the various analyzes in a quick and economic point of view.

Energy consumption analysis, daylighting and lighting control systems, Computational Fluid Dynamic (CFD) modelling, visualization, thermal evaluations, carbon emission calculations, and determining heating/cooling equipment capacity are some principal purpose of utilizing 
DesignBuilder. This computer enables the user to optimize the building performance by calculating energy savings resulted from application of Energy Conservation Measures (ECM) in both residential and commercial building sectors.

EnergyPlus: US Departments of Energy's has developed EnergyPlus as $3^{\text {rd }}$ generation dynamic building energy simulation engine which is the most comprehensive simulation engine. EnergyPlus has been under constant development since it was released. It is a powerful amalgamation of BLAST and DOE-2. Multiple time steps per hour simulation, multi-zone air conditioning system, various renewables, and so forth are features empowered EnergyPlus. It is designed to be used for modelling building, heating, cooling, lighting, ventilating and other energy flows. In order to obtain energy-efficient system engineering, occupant comfort and health, accurate system and plant load size, prediction of space temperature are crucial. So EnergyPlus is the best available simulation engine which found reliable.

Figure 25 indicated the overall EnergyPlus structure and its interconnection with the third-party user interface software like, DesignBuilder, SketchUp, etc. third-party user interface software, which takes data from the user as the building system characteristics (input data) and present output data after simulation. All simulation processes are done by EnergyPlus; the heart of the program is a simulation manager. EnergyPlus has three components: simulation manager, building system simulation and heat $\&$ mass balance simulation module.

Why DesignBuilder? It has been chosen because of its user-friendly interface and its allowance to the user to model a complex building like a data center quick and its well-designed demonstration of results besides, comprehensive available data sets and modules. Noting that, DesignBuilder's motor engine is EnergyPlus and results can be presented in graphs or exported in tabular format in case required to be used or analyzed in another application. 


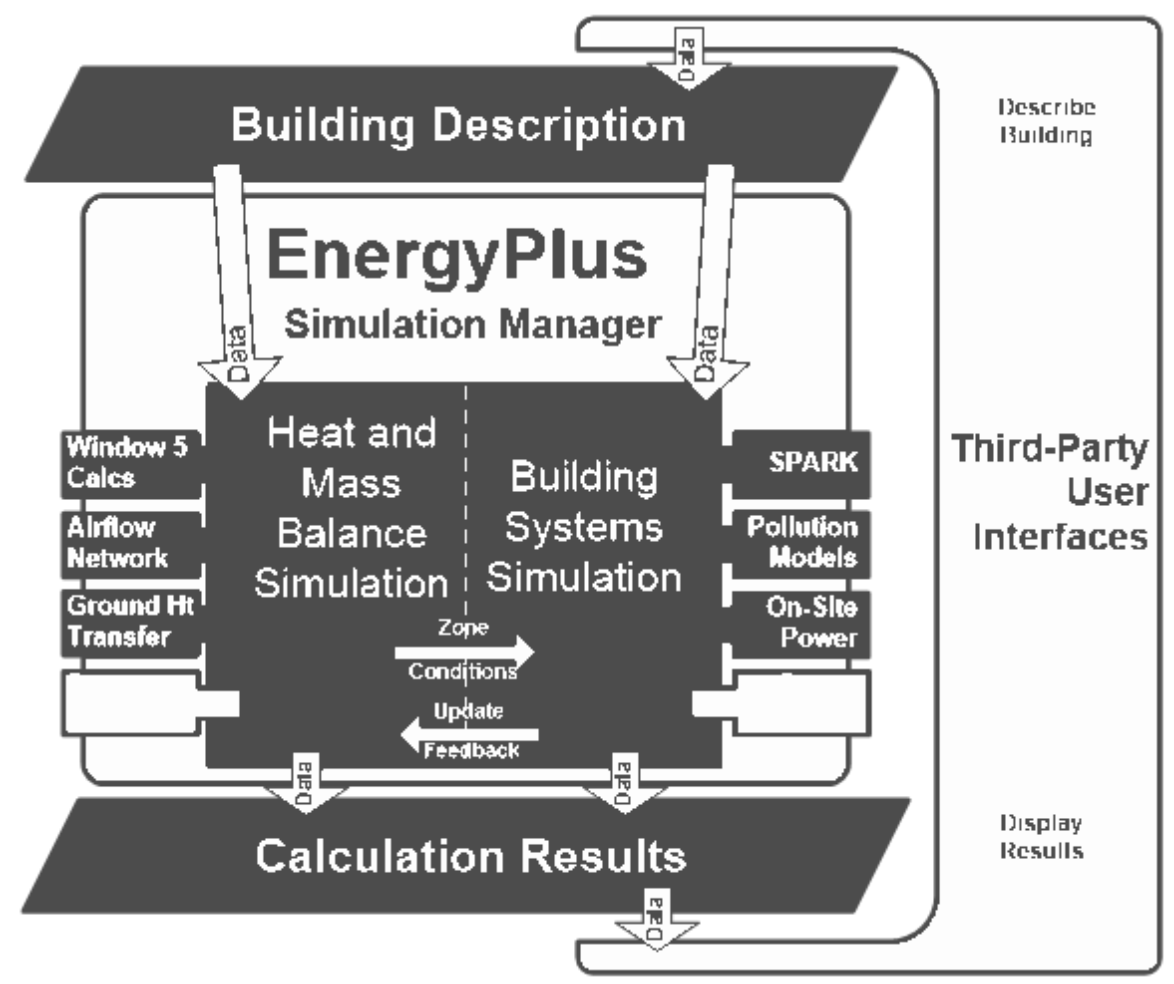

Figure 25 Big picture of EnergyPlus (Reproduced from EnergyPlus Manual) 


\subsection{Environmental Conditions}

Table 9 Class definitions for ITE environment (Ref: Thermal Guidelines for Data Processing Environments, 2012)

\begin{tabular}{|c|c|c|c|}
\hline Classes & Applications & IT Equipment (ITE) & $\begin{array}{l}\text { Environmental } \\
\text { Control }\end{array}$ \\
\hline A1 & \multirow{4}{*}{ Data center } & Enterprise servers, & \multirow[t]{2}{*}{ Tightly controlled } \\
\hline A2 & & storage systems & \\
\hline A3 & & Volume servers, storage & Some control \\
\hline A4 & & $\begin{array}{c}\text { systems, } \\
\text { PC, workstations }\end{array}$ & \\
\hline B & Office, home, etc. & $\begin{array}{c}\text { PC, } \\
\text { workstations, Printers }\end{array}$ & Minimal control \\
\hline C & industrial, factory, etc. & $\begin{array}{l}\text { Point-of-sale equipment, } \\
\text { ruggedized controllers, or } \\
\text { computers and PDAs }\end{array}$ & No control \\
\hline
\end{tabular}

ASHRAE TC 9.9 committee initially published Thermal Guideline for Data Processing Environment 1st edition in 2004 and developed and published up-to-date versions since then. Prior to that, data center designers considered the data center's environmental condition similar to offices with $22 \mathrm{C}+/-2 \mathrm{C}$. Regarding ASHRAE thermal guideline data center, Table 9, defines each class of ITE environment and the level of environmental control they require. Following that, the suitable environmental condition associated with each class is presented in Table 10, and well illustrated in the psychrometric chart (Figure 26). This figure simplified comparing different class types and all other accompanying air characteristics. ASHRAE TC 9.9 has expanded ITE environmental classes to four classes (i.e. dedicated only to data centers) in the $3^{\text {rd }}$ version in 2012. A3 and A4 allow more flexibility in the operation of the facility and contributes to the total energy consumption reduction of the facility. The tendency to loosening limits is in order to achieve higher energy conservation levels, but this needs to be handled carefully to achieve desirable results. Moreover, these two new classes claimed to enable operational efficiency improvement by being more compatible with chillerless cooling systems. (Thermal Guidelines for Data Processing Environments, 2012) 
Table 10 Summary of ASHRAE thermal guidelines for data centers (Ref: Thermal Guidelines for Data Processing Environments, 2012)

\begin{tabular}{clll}
\hline & Dry-bulb Temperature & Humidity range & $\begin{array}{l}\text { Maximum Dew } \\
\text { point }\end{array}$ \\
& Recommended & & \\
Class A1 and & $18-27^{\circ} \mathrm{C}$ & $5.5^{\circ} \mathrm{C}$ DP to $60 \%$ & - \\
A4 & & RH and $15^{\circ} \mathrm{C}$ & \\
& & DP & \\
& Allowable & & $17^{\circ} \mathrm{C}$ \\
Class A1 & $15-32^{\circ} \mathrm{C}$ & $20-80 \%$ & $21^{\circ} \mathrm{C}$ \\
Class A2 & $10-35^{\circ} \mathrm{C}$ & $20-80 \%$ & $24^{\circ} \mathrm{C}$ \\
Class A3 & $5-40^{\circ} \mathrm{C}$ & $8-85 \%$ & $24^{\circ} \mathrm{C}$ \\
Class A4 & $5-45^{\circ} \mathrm{C}$ & $8-90 \%$ & \\
\hline
\end{tabular}

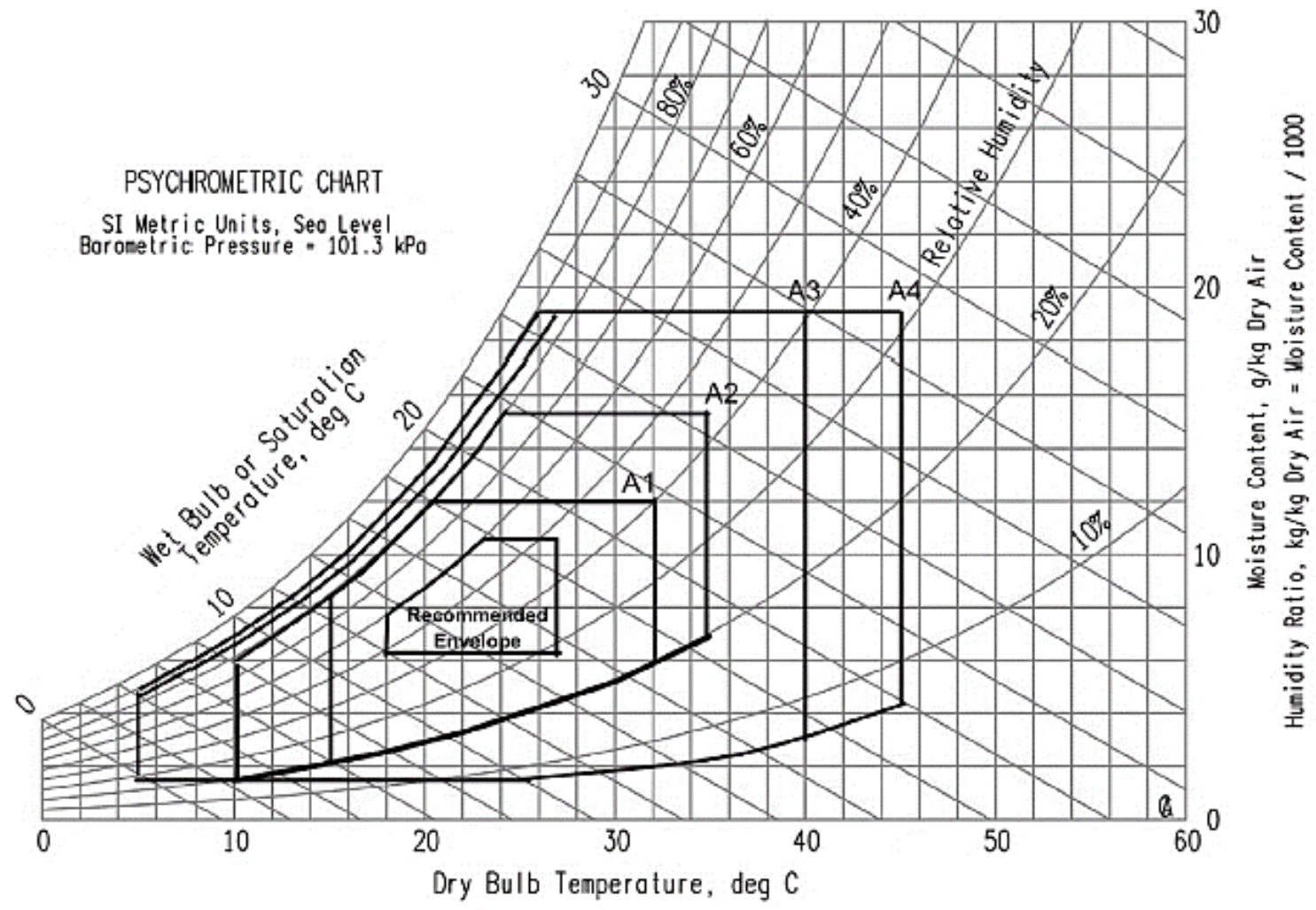

Figure 26 "ASHRAE thermal guideline for data center operating environment" - SI Unit (Ref: Thermal Guidelines for Data Processing Environments, 2012) 


\subsection{Methods of Modelling ERC's Data Center}

Modelling the existing system might seem straightforward and simple. However, each modelling software has some limitations that make energy modeller come up with some solutions. Some historical data for the ERC's data center was obtained from 2015 to 2018. But, 2018 has been chosen as the main simulation length of this study. These datasets will be used as a calibration baseline in the final section of this chapter.

Figure 27 depicts simulation hierarchy used. Location set defines the geographical location and related weather data file (Step 1). Simulations continued with modelling geometries and setting up several input parameters in the software. This step allows proper calculations for accurate heat conduction and convection between zones of different temperatures (Step 2). The breakdown list of zone envelope characteristics and thermal behaviour are listed in appendices. Space internal Loads like occupants, lighting and internal heat generating equipment were defined next (Step 3). Noting that anything assigned and assumed in the first three steps remains consistent throughout different scenarios. By assigning proper HVAC configuration to each scenario, the simulation would be ready for running (Step 4). The simulation was made mainly based on daily analysis throughout the year, except for detailed investigations or cooling load calculations, where summer design week and summer design day (July $15^{\text {th }}$ ) were considered, respectively (Step 5). In the end, results of the chosen scenario are analyzed, and one compatible with existing data center's HVAC configuration is proceed for calibration. This is the key step of this study. Calibration of the model is done by comparing resulted data with actual recorded data.

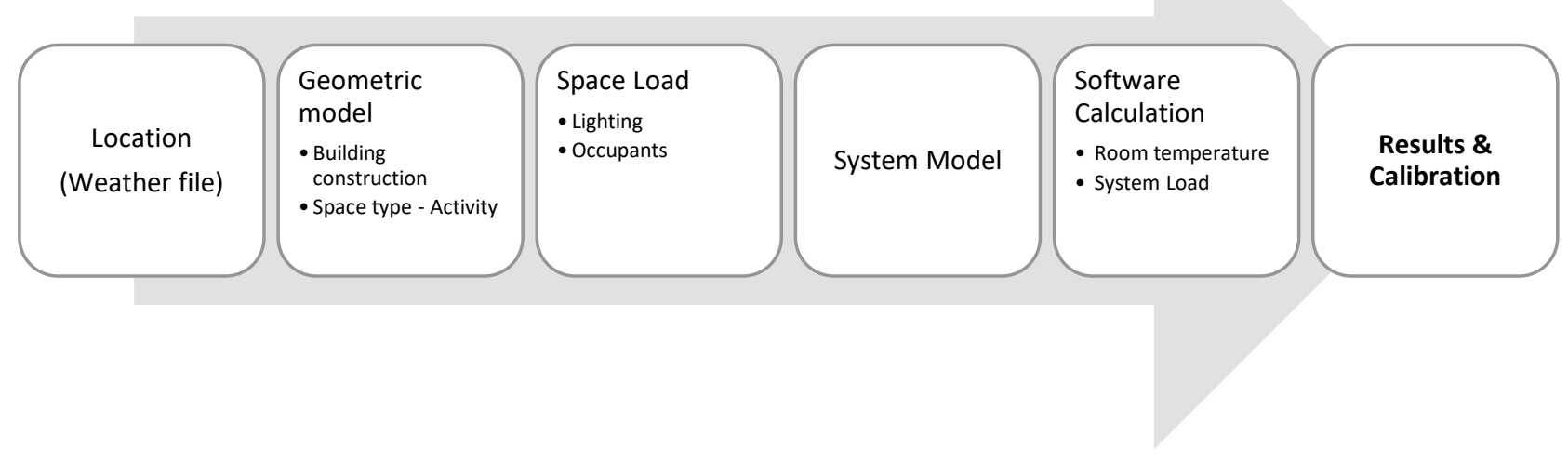

Figure 27 Graph of modelling strategy 


\section{Weather File:}

The Earth Rangers center is located in the Kortright Conservation Area in Woodbridge, Ontario. Woodbridge has a humid continental climate with annual temperature variation (hot, humid summers and cold, snowy winters). It is located at latitude and longitude of 43.8 and -79.5 , respectively. The average temperature in summer is $21 \mathrm{C}(70 \mathrm{~F})$ in July as the hottest and Jan as the coldest month with an average of $-3 \mathrm{C}(28 \mathrm{~F})$. Statistics of recorded weather in 2018 is provided in Appendix B.

\section{Zoning:}

The data center is surrounded by corridors from two side and two semi storage rooms (conditioned) from the other two sides. The data center is located on the ground floor, adjacent to open space office area from the top and large storage room in the basement.

In the data center room, regards to the fact that the underfloor air distribution area occupies about $15 \%$ of total volume, it is assumed as a separate zone in the model (Plenum). So a single zone is dedicated to the main room. A single-zone model was utilized to isolate the complexity of building loads and keep the focus on the HVAC system performance. In the DC, it assumes that air within the zone is evenly mixed. And, zone air temperature is uniform throughout the room. However, in a real data center case, the air temperature varies within the zone, and surfaces in the regions that have different air temperatures exchange infrared (IR) radiation with the other surfaces within the zone (Engineering Reference - Energyplus 8.0 - Big Ladder Software).

\section{Occupancy:}

Occupancy behaviour plays an important role in the simulation. The occupancy schedule set to Monday to Friday 9AM-5PMwith consideration of Canadian holidays. Cooling design calculation and whole other simulation processes use this data in conjunction with the metabolic heat output and occupancy schedule to calculate total heat input by people to the zone load.

\section{Air-Conditioning System Design:}

Regards to the HVAC system, the data center is cooled with an In-Row Rack Cooling (RC) unit, connected to a geothermal heat pump system. In ERC, the chiller is used for conditioning air for the whole building. While, according to the ERC's facility manager declaration, data center only utilizes chiller, exceptionally in some days during summer when the cooling load cannot be met by geothermal alone. Therefore, in following proposed system modelling scenarios, use of chiller is eliminated to benefit the most from free cooling. Moreover, assess if following system 
design options can meet the data center load without chiller usage. A separate chiller and boiler are assigned to other zones (excluding data center) to maintain setpoint air temperature due to potential heat transfer between the data center and surrounding zones. Chiller and Boiler usage will not be included in any system load results.

Proposed HVAC system models are described in each section. An HVAC system is the only difference between three scenarios. Scenario A: combined heat pump and ground heat exchanger serving zone FCU. Scenario B: ground heat exchanger combined with a 4-pipe heat exchanger serving zone FCU. Scenario C: Parallel heat pump and heat exchanger connecting ground source heat exchangers to the zone FCU. All three-design option are described and illustrated in detail in the following section. All cases connected directly to the geothermal heat exchanger. And chiller use is eliminated. Differences in this section command software's simulating engine to develop results according to the proposed system type and the only reason for different calculated outputs.

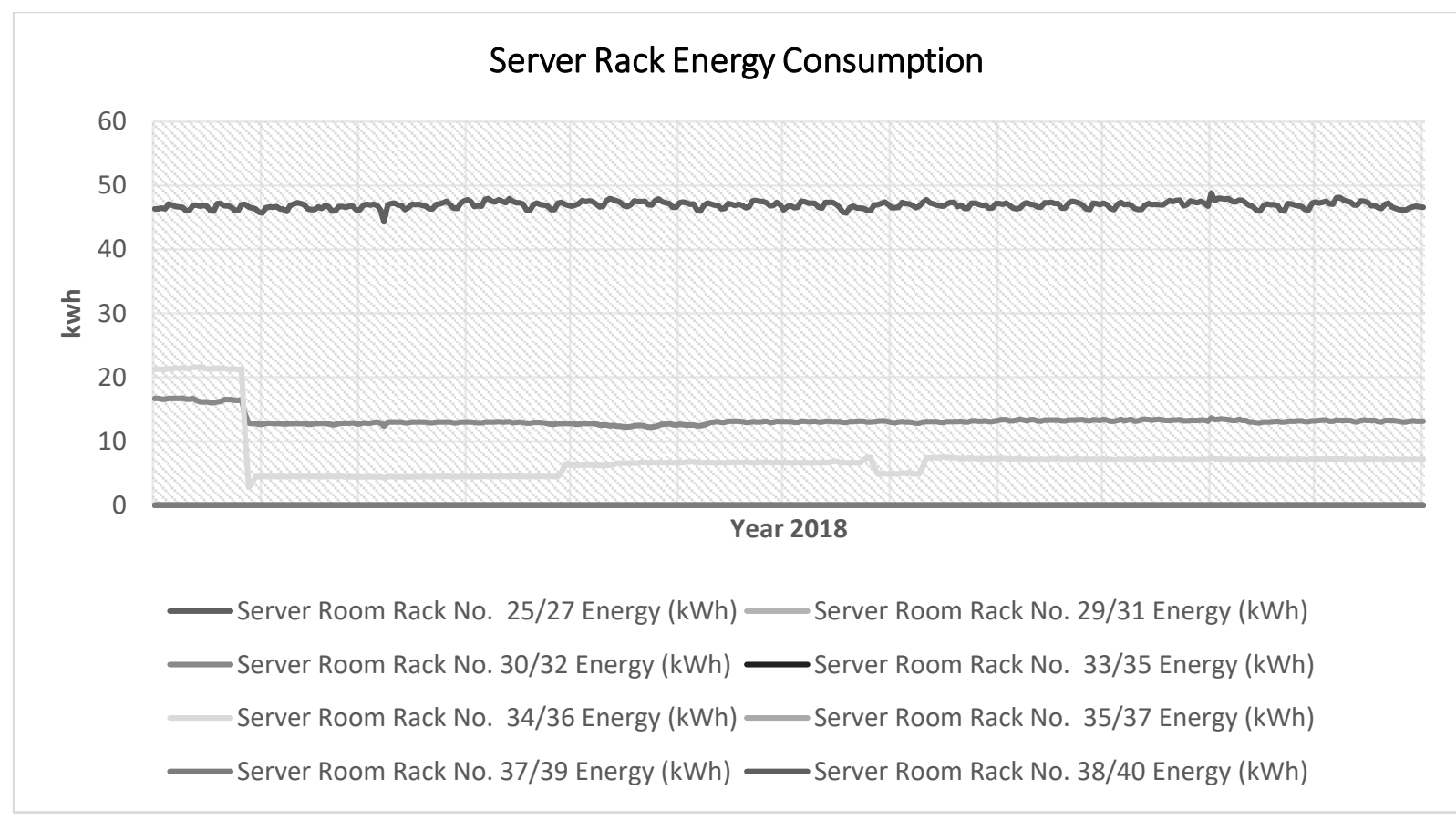

Figure 28 Server racks electricity consumption breakdown (Recorded data)

Server room rack electricity consumption is relatively constant throughout 2018 (Figure 28), according to original data recordings. This is the same by lighting and load heat load generated by people in the zone. Therefore, the cooling coil power trend is expected to have relatively smooth changes relative to ground source heat exchanger outlet temperature. 


\subsection{Scenario A}

System Description: The GCHP (ground coupled heat pump) system proposed in scenario A consists of major parts such as ground heat exchanger, Heat pump system, circulating water pumps and fan coils. This is the existing configuration of Earth Rangers Center, without consideration of the chiller.

The load side of the zone comprises a fan Coil Unit with a 24/7 running fan equipment. The condenser loop is the source side (water) of the heat pump with a ground heat exchanger. In this study, regarding Figure 29, the ground heat exchanger is coupled with a liquid-to-water heat pump. In terms of energy simulation, so-called parameters need factors to define the functioning conditions of each integrated equipment. Regarding manufacturers' catalogue data sheets and collected information from ERC's facility manager, those factors are defined in the software. The remaining is left to be authorized by simulating software. Further investigations would show whether assumptions and DesignBuilder's autosize mechanism performs accurate or not.

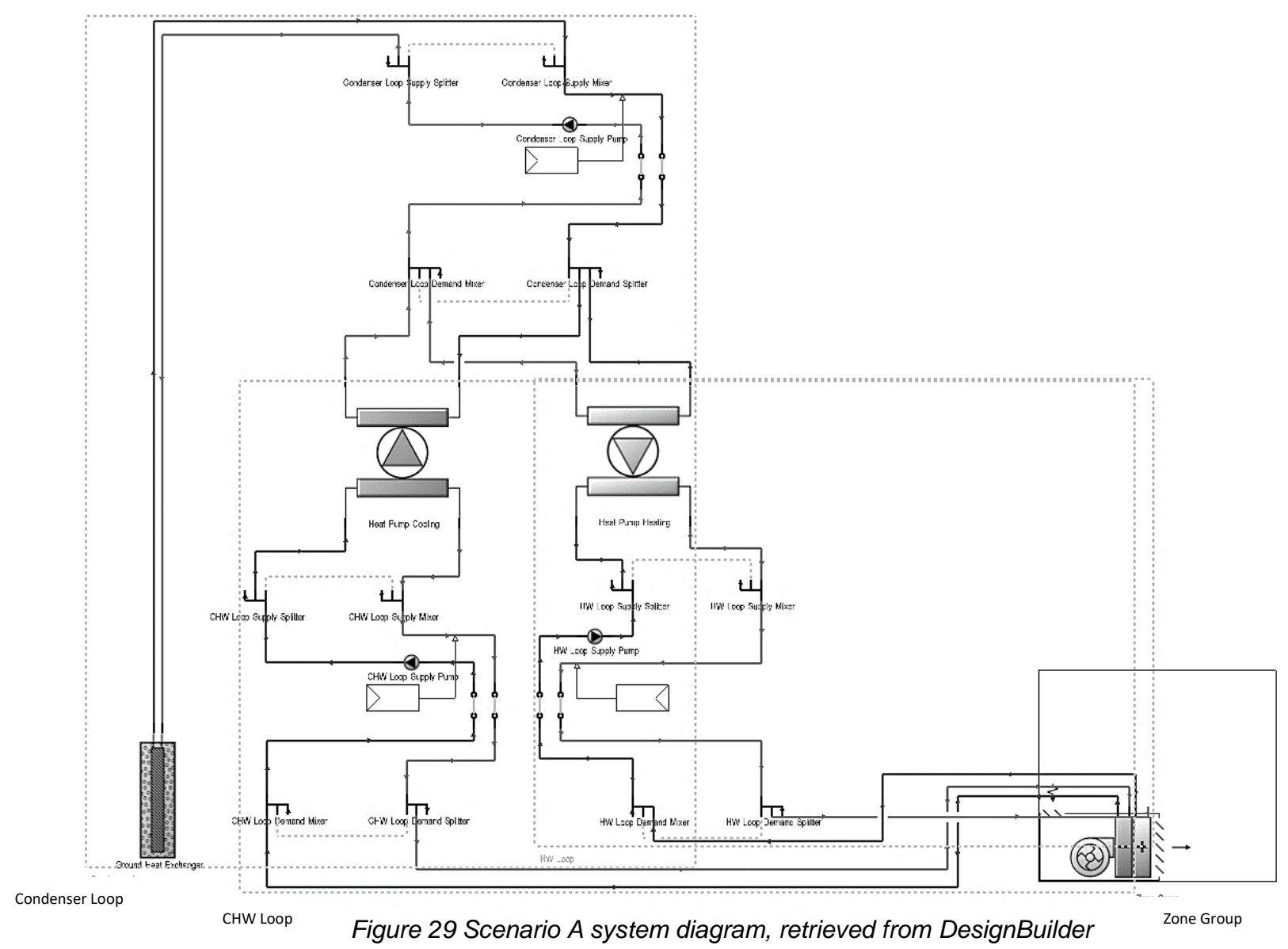




\section{Ground Source (Geothermal) Heat Pump:}

System performance is very dependant on design input parameters, temperature and ground thermal properties. Ground Source Heat Pump (GSHP) can achieve higher efficiency level when combined with a system that operates at low temperature. Specifically, during the cooling season, ground, as a heat source/heat sink which has a relatively stable temperature, is lower than outdoor air. Energy requires for precooling the outdoor air is eliminated with utilizing ground heat source. Subsequently, Geothermal heat pump systems are beneficial in reducing environmental impacts with the use of a free source of heat (Lucia et al., 2017).

Earth-energy systems intend for closed-loop applications have cooling EER ratings between 13.4 to 25.8 and heating COP ratings range from 3.1 to 4.9 . In Canada, winter ground temperature is typically between $-2 \mathrm{C}$ and $4 \mathrm{C}$ where the air temperature can go below $-30 \mathrm{C}$. earth-energy systems claimed to have COP range from 2.5 to 3.8 (Ground-Source Heat Pumps, NRC, 2019).

In a data center that requires constant cooling operation throughout the year, this system has advantages as direct cooling of outdoor air at peak temperatures increase energy use substantially. According to Our Facility - Earth Rangers. (2013), the geothermal system can move 300 units of heat per pumping energy unit from building to the ground in free cooling mode.

Figure 30 shows a typical configuration of a GSHP system. Temperatures are arbitrary figures only showing cooling/ heating mode performance. The ground is the heat sink for heat being rejected in Cooling mode.

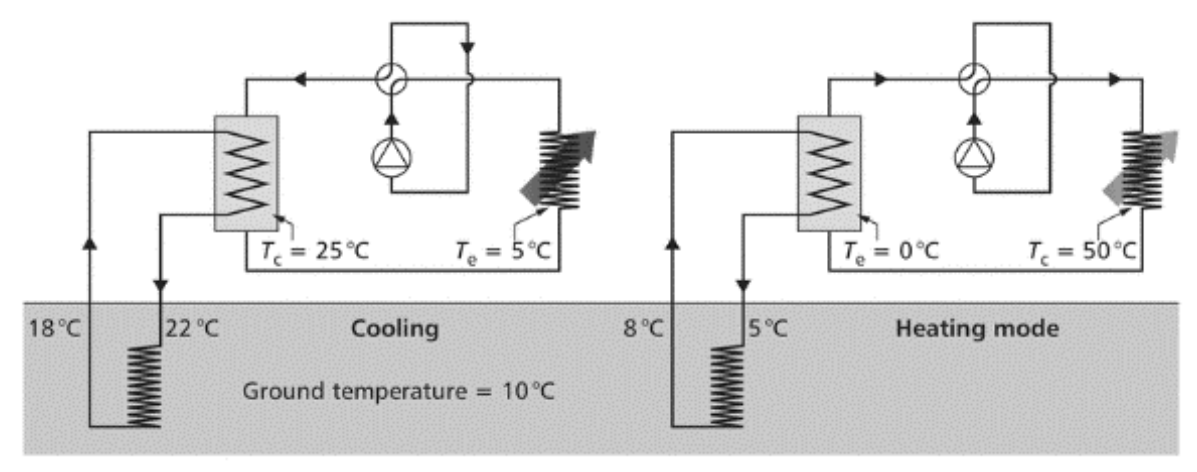

Figure 30 General design of the geothermal heat pump system. Condensing and evaporation refrigerant temperatures are shown by Tc and Te, respectively. (Image Source: CIBSE, 2013) 
Borehole Heat Exchangers: Earth Rangers center has closed-loop GSHP system. In a closedloop system, a high-density polyethylene pipe is buried either vertically (Figure 23) or horizontally in the ground to rejects or extracts heat from the lower levels of ground. The vertical depth of pipes in a closed loop system is generally between $30.5-120 \mathrm{~m}$ with $76-127 \mathrm{~mm}$ borehole diameter (Lucia et al., 2017). Earth Rangers' boreholes are buried up to 120m deep in the ground. The fluid inside the heat exchanger (pipes) can be water or an antifreeze solution to prevent freezing below the ground. In ERC $20 \%$ Glycol is used with water.

For further data regarding the temperature of extracted fluid from the ground and that of leaving from the heat exchanger or vice versa, the detailed temperature trend in 2018 is provided in Appendix A.

Fan Coil Unit: In-row rack cooling management application depicted Cooling demand and cooling output of $10.6 \mathrm{KW}$ and $7.6 \mathrm{KW}$, respectively. ACRC100 has horizontal air discharge pattern and rear return with a maximum airflow of 2900 CFM, where minimum water inlet temperature is not allowed to be lower than $45 \mathrm{~F}(7.2 \mathrm{C})$.

\section{FINDINGS}

System Load: System cooling sizing is the result of analysis on the hottest day of the year (July 15th, 2018). Table 11 summarizes the calculated system design load based on user inputs and software calculations. Moreover, the graph below depicts monthly total cooling rate of the data center room through 2018. Cooling rate peaks in July and has its lowest rate in the first two months of the year.

Table 11 Calculated HVAC design summary

\begin{tabular}{|l|l|l|l|}
\hline Design Capacity [kW] & 10.7 & Design Flow Rate [m3/s] & 1.4548 \\
\hline Total cooling Load [kW] & 9.3 & Sensible [kW] & 9.01 \\
\hline Latent [kW] & 0.29 & Air temp [C] & 18 \\
\hline Humidity [\%] & 68.5 & Time of max cooling & July $15: 00$ \\
\hline Max Op temp in day [C] & 21.9 & Floor Area [m2] & 15.7 \\
\hline Volume [m3] & 44 & Flow/ Floor Area [l/s.m2] & 92.6 \\
\hline design cooling load per Floor Area [W/m2] & 680.8 & Outside Air Temp at peak Load [C] & 31.4 \\
\hline
\end{tabular}




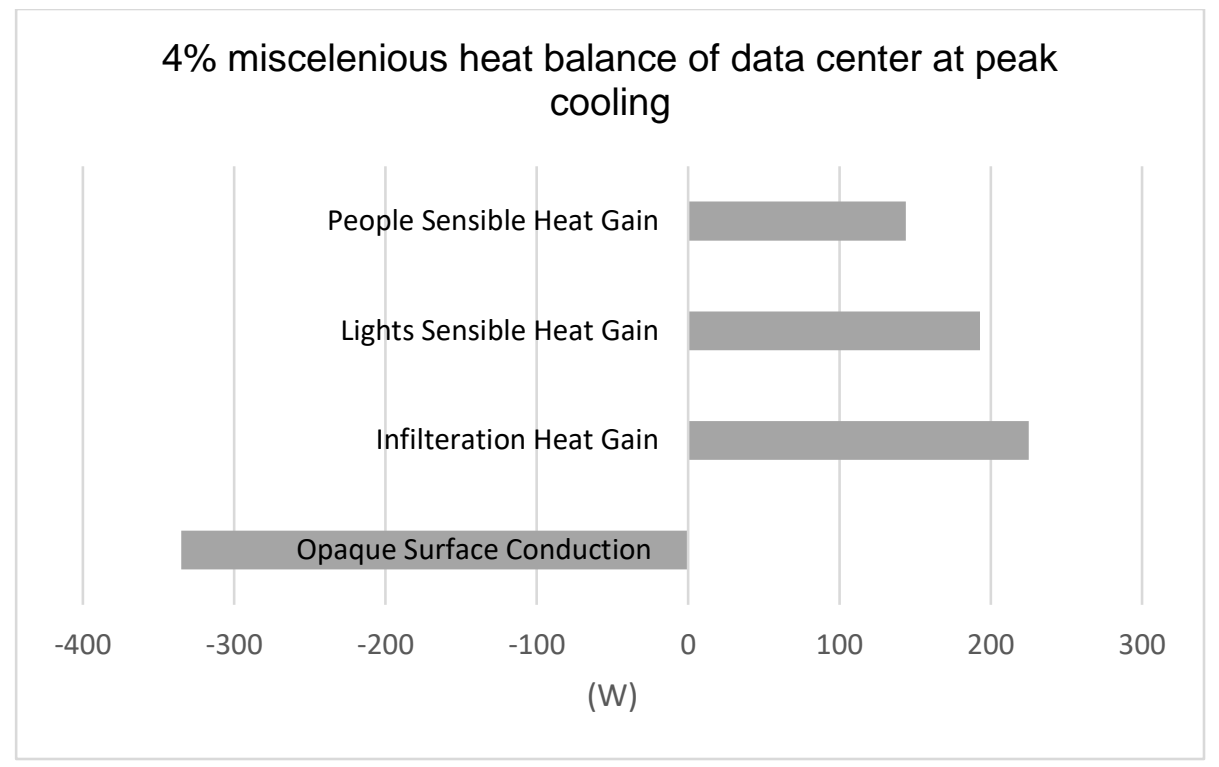

Figure 31 Heat balance of miscellaneous loads at the peak in Scenario A

Miscellaneous loads, within the data center zone, accounts for only $4 \%$ of the total. Figure 31 shows the individual influence of them on system design load. Opaque surface conduction helps lowering cooling load, even with small contribution relative to the total. Although glazing seems to have opposite direction of heat transfer (i.e. adding to heat load). Therefore, future optimization on glazing units would help mitigating total heat load even very minor. It also increases the advantage of envelope behaviour on the overall performance of the zone (Figure 32).

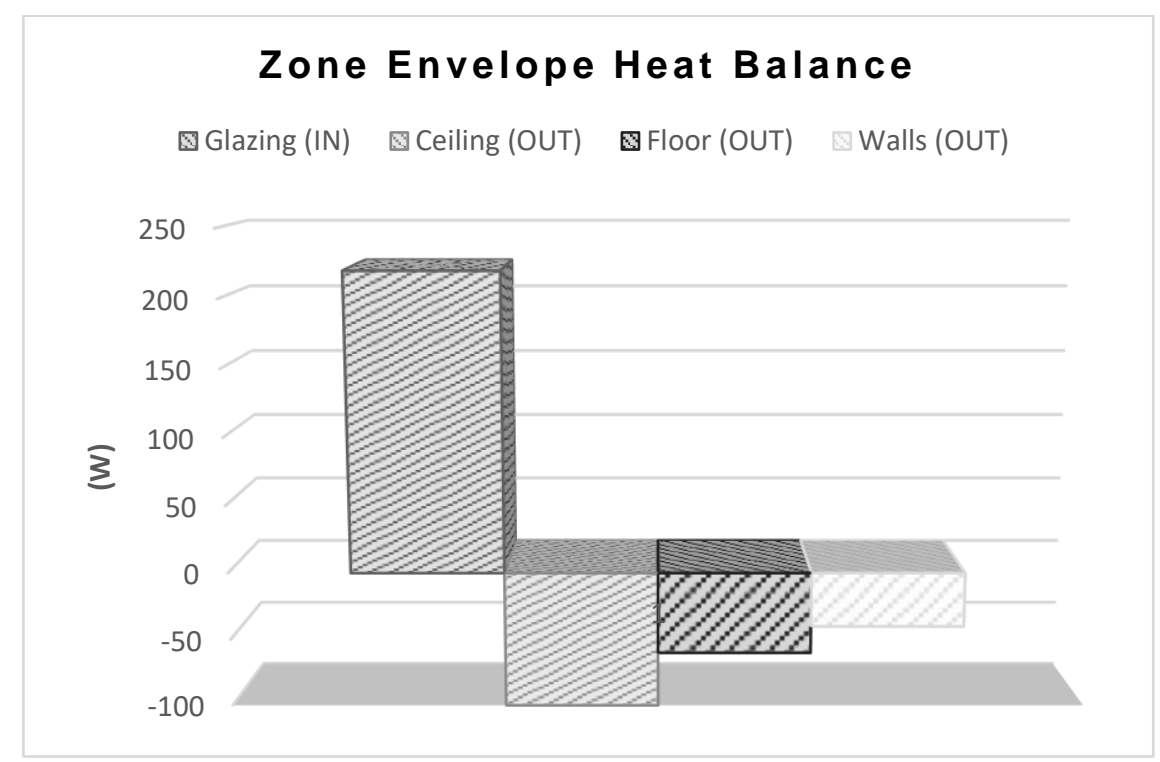

Figure 32 Zone Envelope Heat Balance 


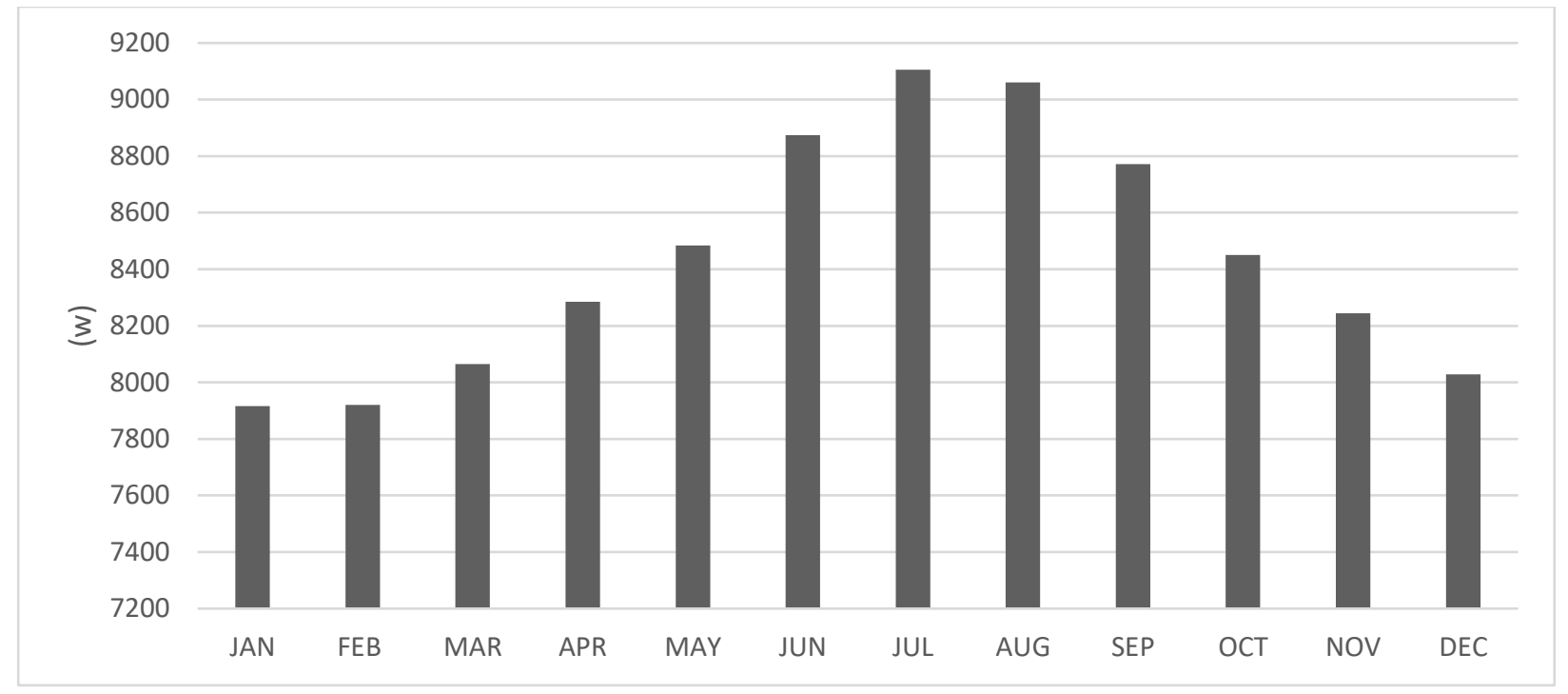

Figure 33 Monthly total cooling rate of FCU - Scenario A

Indoor Air Temp: As a result of using GSHP cooling configuration the temperature is kept within the recommended temperature by ASHRAE $\left(18-27^{\circ} \mathrm{C}\right)$ during the use of geothermal heat pump throughout 2018. Temperature set point has not met only $5 \%$ of the time in the whole year. It was recorded at highest $20^{\circ} \mathrm{C}$ and average $41 \%$ relative humidity. Annual average Data center area is initially planned to be conditioned by the same approach as this scenario (B), referring to mechanical documentation.

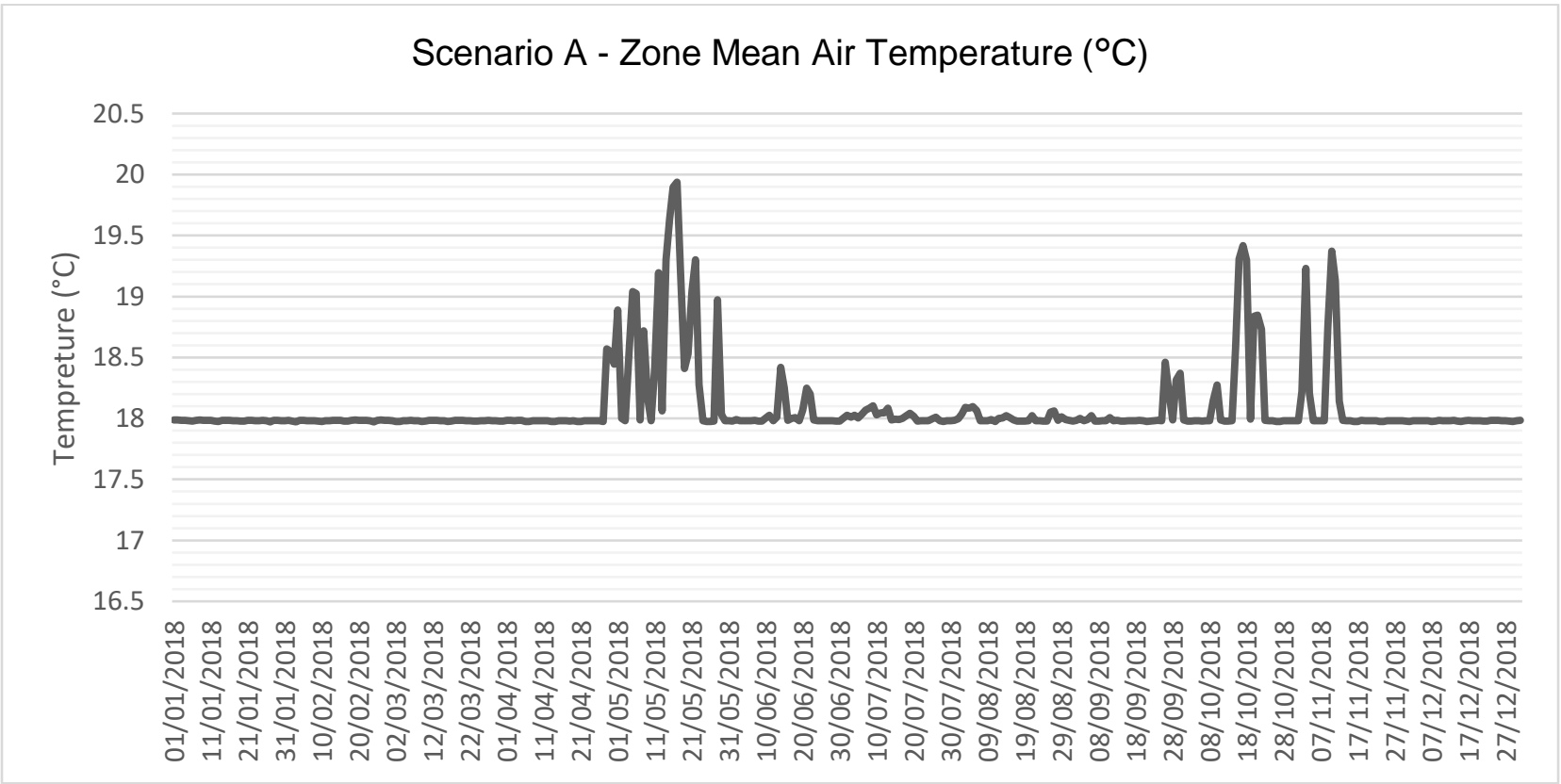

Figure 34 Indoor air temperature (Scenario A) 


\subsection{Scenario B}

System Description: Scenario B is the approach of benefiting free cooling. In this approach, fan and pumps are leading contributors to electricity consumption. This approach is similar to bypassing of a heat pump in the previous scenario, except for the fact that, more pumping power and influence of heat exchanger would be considered. Referring to Figure 35, the system includes a ground heat exchanger, interconnected to fan coil unit through a central heat exchanger.

This system modelling is a result of the combination of heat transfers between fluid (water with $20 \%$ Glycol) and air. Load side consists of an air loop which delivers the entire forced air cooling for cooling server racks and common data center area. Then, heat transfer occurs through the air passing cooling coils (water to air). The fan is the system component performs as the forcing power.

Outside the zone, Chilled Water Loop (water side) comprises of pipes connecting cooling coils to a heat exchanger unit (HX-5 according to the mechanical drawings) and circulating water pump, operates and controlled by the automation system. Bypass may also occur in case needed. The heat exchanger is where another Fluid to Fluid heat transfer occurs.

Transferring excessive heat outside is what happens in the condenser loop. HX-5 exchange heat between supply side and demand side and release heat into the ground via buried pipes in the ground.

Illustrated graph is dedicated only to data center zone. As mentioned, for more clear results and as our focus is only one part of a large facility, other zones are assumed to air-condition by separate chiller and boiler. (Figure 35)

DesignBuilder limits us with two parallel connected sets of coils, one for cooling and the other serves for zone heating. Regarding the characteristics and requirements of a data center, heating is not required at any time. So, the heating coil in all scenarios is considered zero.

A fluid-to-fluid heat exchanger used to connect two loops in general (demand side of condenser loop to supply side of CHW loop in Scenario B). Heat loss in heat exchanger unit (HX-5) is slight and it has neglected throughout the study. 


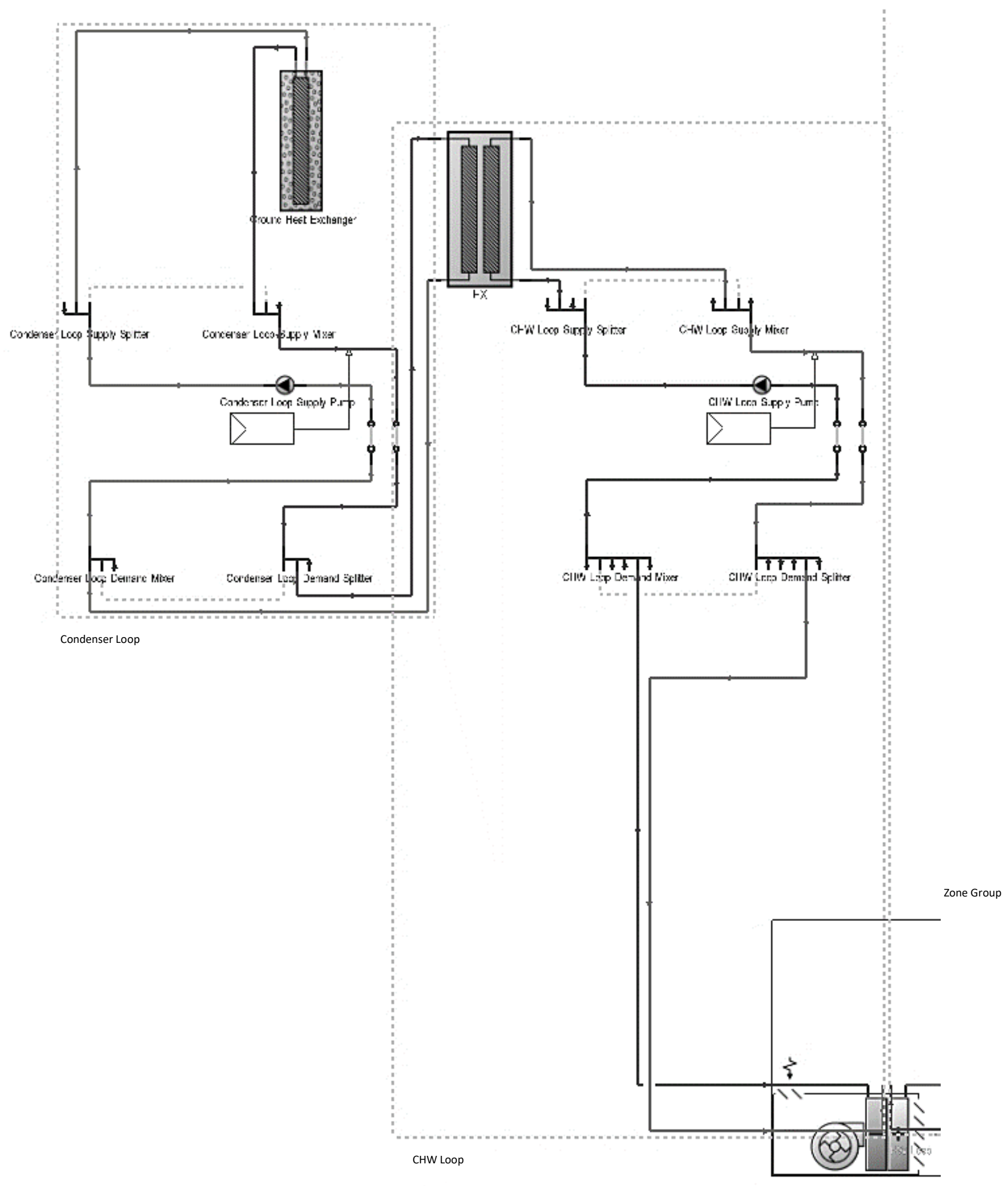

Figure 35 Scenario B, system diagram, retrieved from DesignBuilder 


\section{FINDINGS}

System Load: Fan Coil Unit (FCU) as terminal units of the DC's air conditioning system.

Scenario B obtained annual average cooling coil rate of $7142 \mathrm{~W}$ for data center zone in 2018.

$1.2 \mathrm{kw}$ decrease comparing to Scenario A resulted.

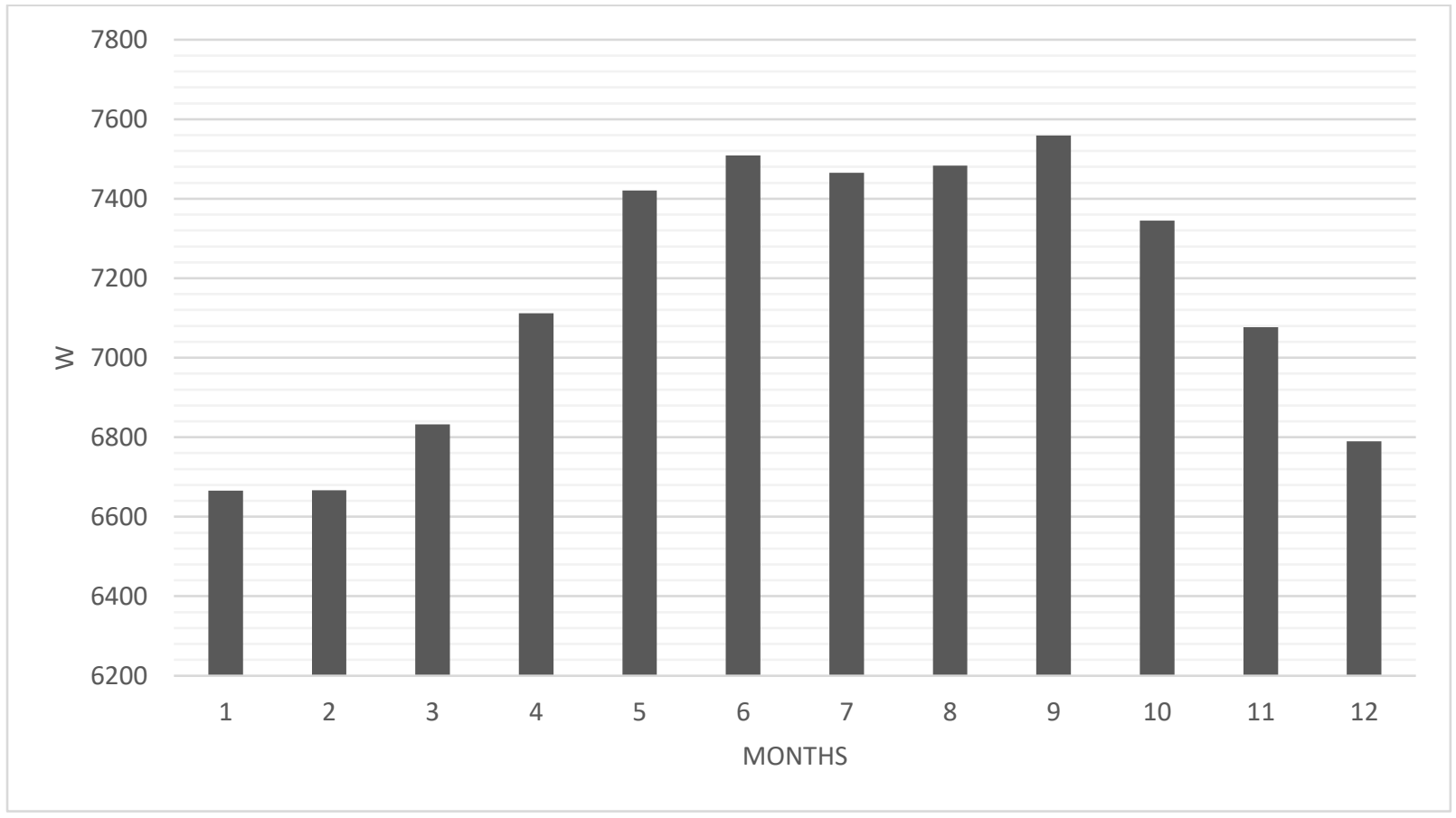

Figure 36 Monthly total cooling rate of FCU - Scenario B

\section{Indoor Air Temp:}

In scenario B, where neither the heat pump unit nor chiller is used for temperature reduction of ground source heat exchanger fluid. Basically, in this case, the setpoint is never met. Figure 37 clearly shows that the current zone temperature is nothing close to the existing situation. But this scenario is where fan power and pump power are the most electricity consumers. According to the graph, only in the winter time, indoor air temperature remains within the recommended zone. And summer, backup cooling is required.

Since flow pattern of zone temperature in this scenario is what is aimed, adding to the point that, electricity consumption is very low for almost half a year, this scenario is set as the baseline model for the rest of this study. Further calibration measures will be introduced for achieving more realistic results based on cooling setpoint temperature. 


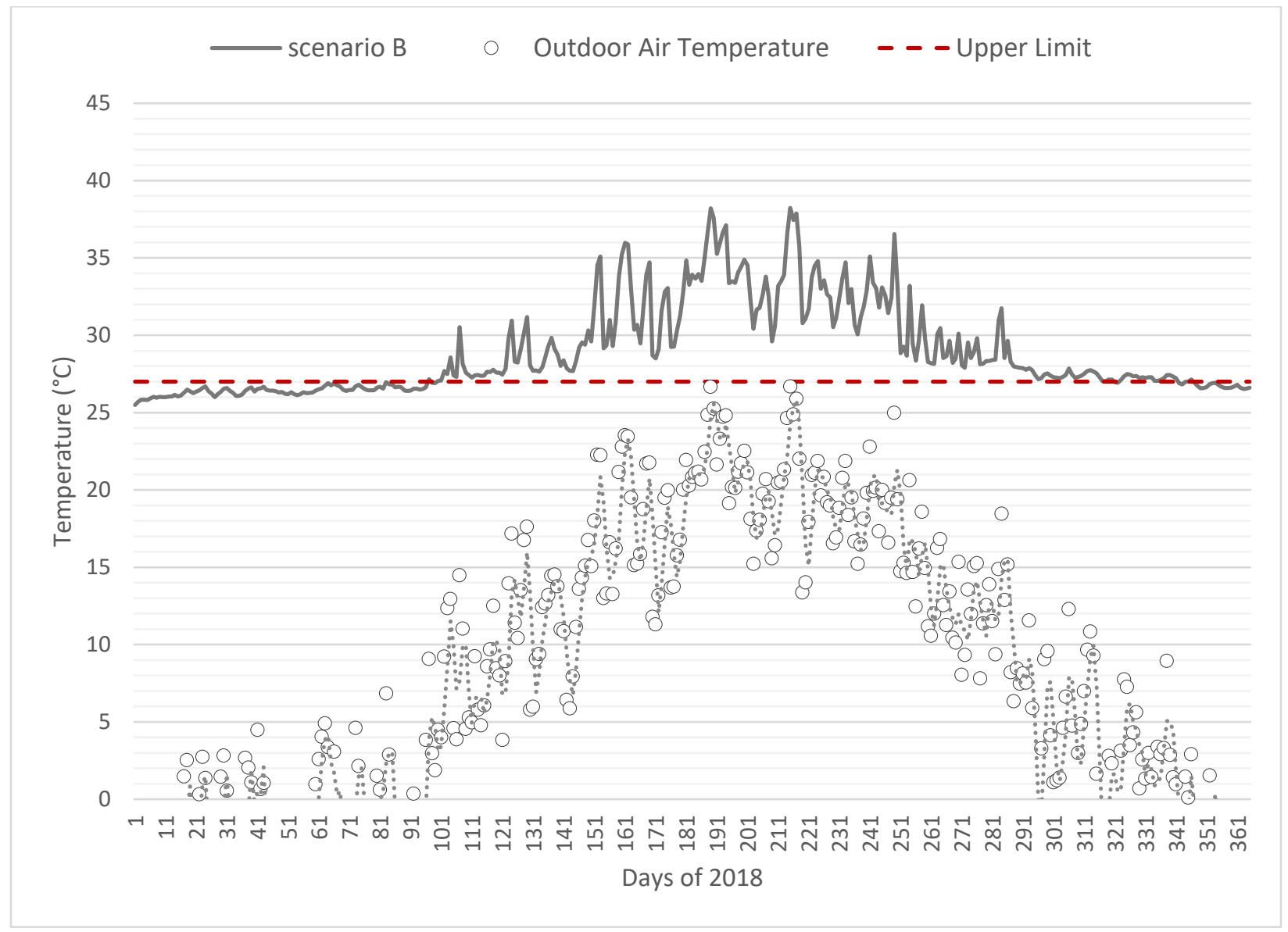

Figure 37 Data center indoor air temperature in scenario B vs. outdoor dry-bulb air temperature 


\subsection{Scenario C}

System Description: Last proposed HVAC configuration is the combination of both scenarios. The parallel connection between the heat exchanger unit and heat pump is explored in this setting.

This system works based on setting priority for fluid circulating in the condenser loop. The schedule is set in this way that fluid should pass through HX-5 unless the desired cooling load could not meet.

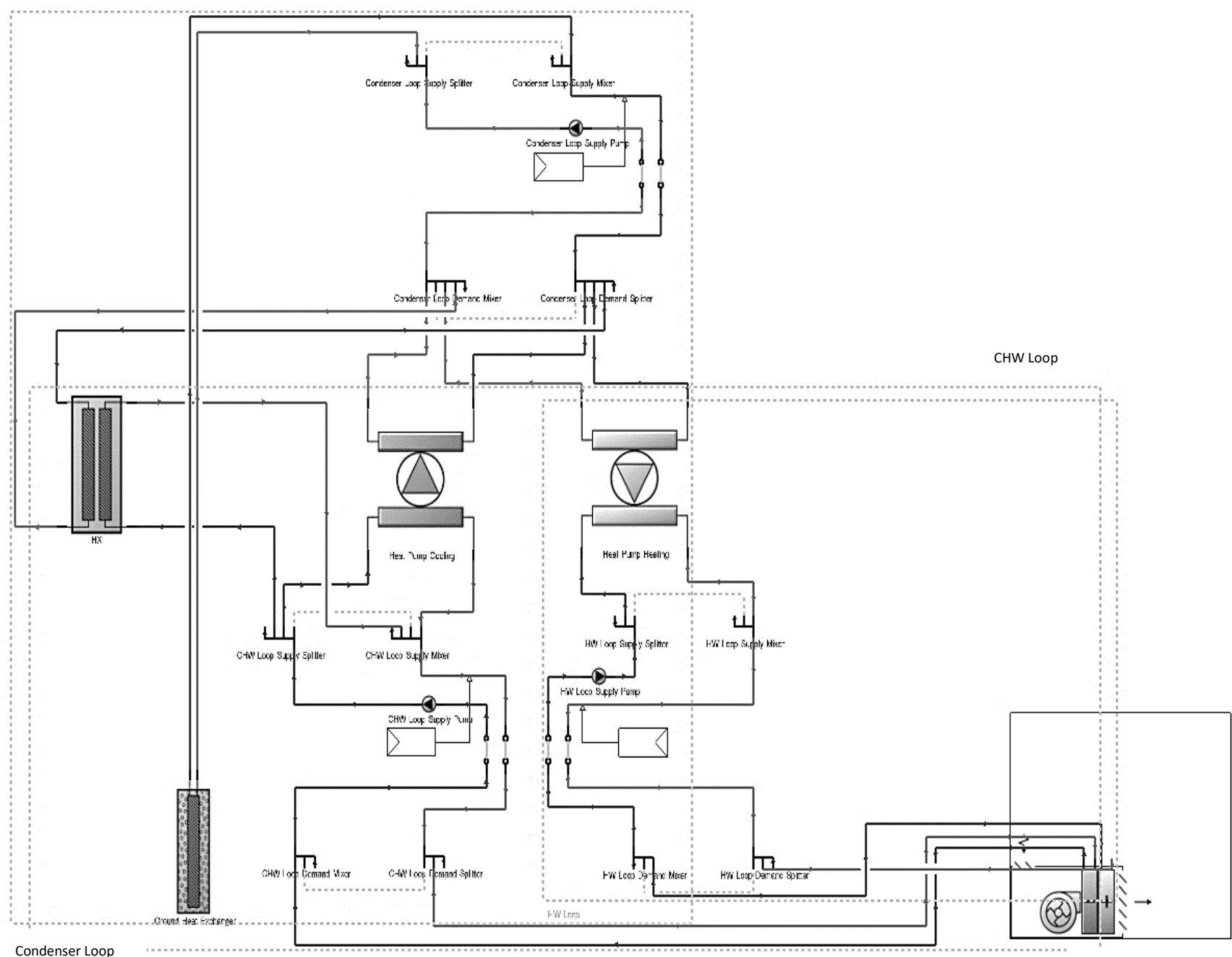

Condenser Loop

Figure 38 Scenario C system diagram, retrieved from DesignBuilder 


\section{FINDINGS}

System Load: FCU design capacity is the same in all configurations as expected. The monthly cooling rate of FCU in this scenario starts below $7800 \mathrm{~W}$ in winter and peaks at almost $8800 \mathrm{~W}$ in July (Figure 39). Interior equipment is responsible for the most significant ratio, $8688 \mathrm{~W}$ internal load. Removing this amount of energy is possible by such configuration that reaches $8800 \mathrm{~W}$ at its peak and $8072 \mathrm{~W}$ of annual cooling rate (calculated by modelling software).

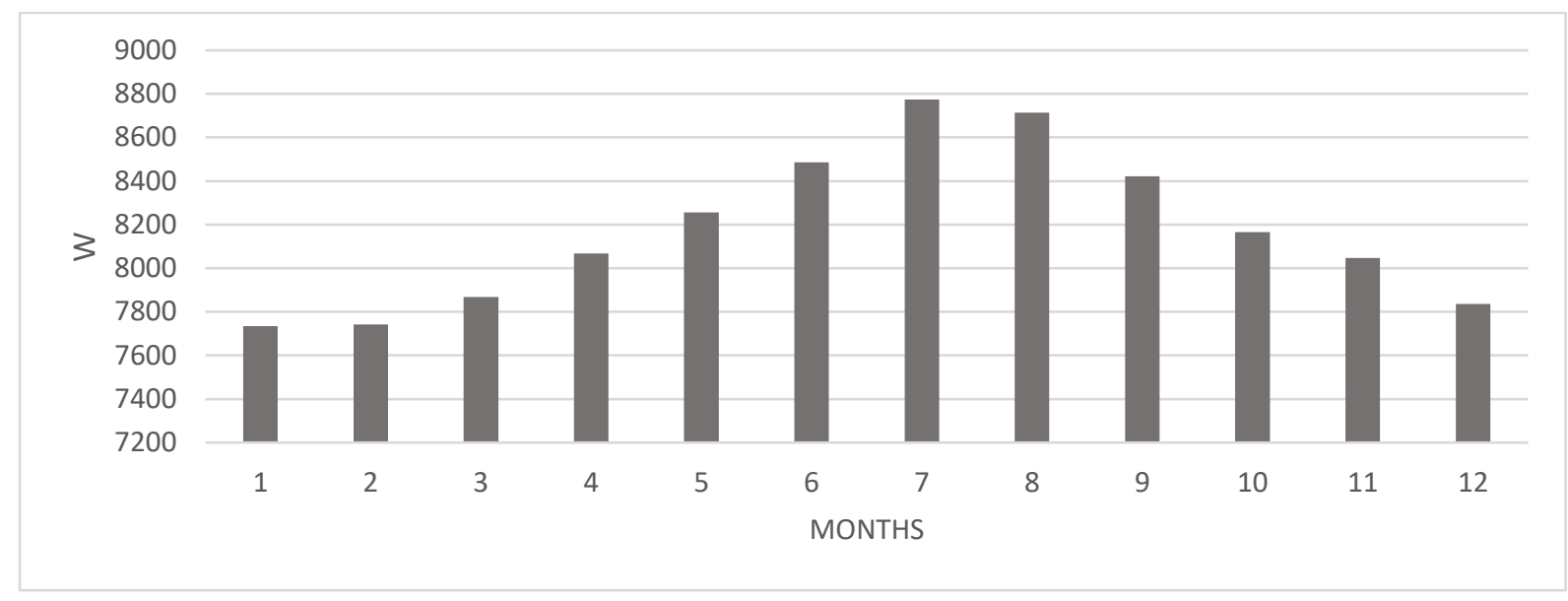

Figure 39 Monthly total cooling rate of FCU - Scenario C

Indoor Air Temp: This configuration has kept indoor air temperature always in the desired temperature range $\left(18-23^{\circ} \mathrm{C}\right)$. This shows an ideal temperature range that summer zone air temperature at the peak does not exceed $23^{\circ} \mathrm{C}$. On the other hand, due to the high temperature of the ground, without the use of heat pump reaching $18^{\circ} \mathrm{C}$ setpoint has not resulted, but results are entirely acceptable when less electricity is needed.

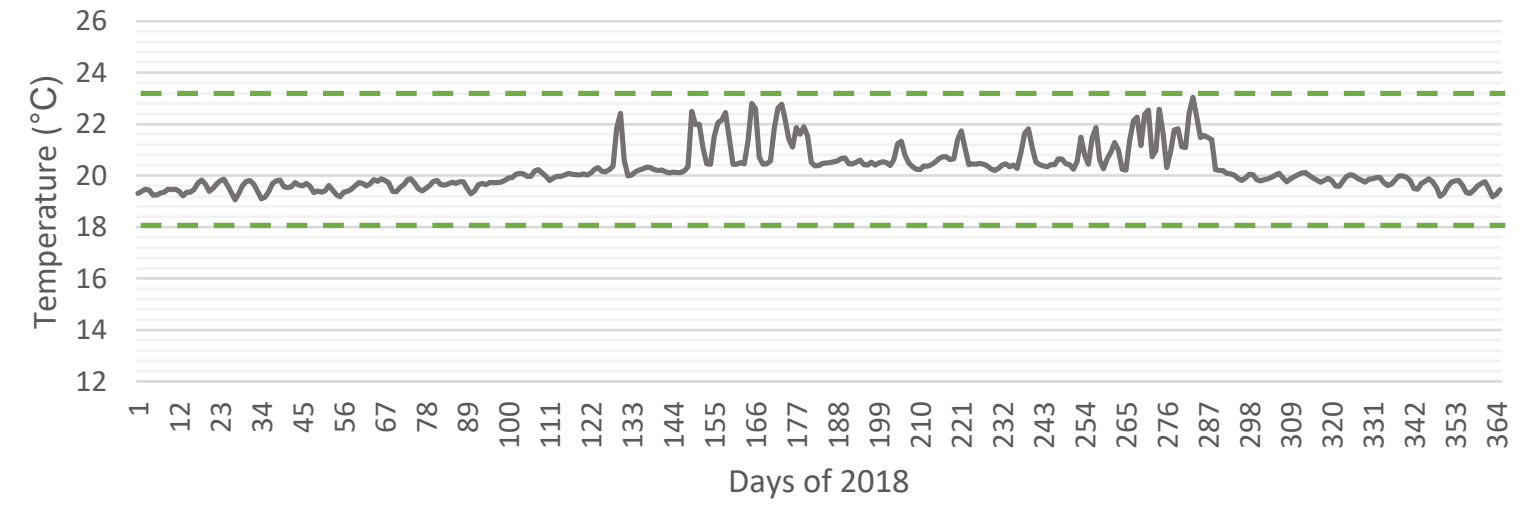

Figure 40 Data center's indoor air temperature in scenario $C$ 


\subsection{Model Calibration and Results}

Regards to the fact that we are seeking to achieve a final model with least electricity consumption by chiller or heat pump, this section will proceed with further investigations over Scenario $\mathrm{B}$, where the heat exchanger unit (HX-5) connects ground heat exchanger to zone cooling coils. Neither chiller nor heat pump is used in the baseline model.

A set of measures has been selected for model calibration; Adjustment of ground temperature according to location, geothermal borehole detail adjustments as an assessment of fluid flow rate alteration in heat exchanger unit and evaluation of the influence of raised floor plenum. However, two were included and reported. Based on that they were the most effective and more relevant measures to ERC's data center's case.

Comparisons have been made between proposed adjustments and the baseline. Effect of each method on overall electricity use of HVAC components serving data center is evaluated and compared to electricity used by typical application of GSHP. Characteristics of the base model are listed in Appendix D.

\subsection{Effects of Fluid Flow Rate}

Heat exchanger unit in Scenario B was autosized by DesignBuilder. Calculated fluid flow rate for fluid-to-fluid heat exchanger (HX-5) is stated $0.0008 \mathrm{~m} 3 / \mathrm{s}$. According to live data collected from one of the site visits, the heat exchanger flow rate was presented $7.95 \mathrm{~L} / \mathrm{s}$. Accordingly, noted assumption had been made. Status of the heat exchanger at the baseline model and assumed adjusted flow rate is stated in (Table 12). Basically, autosized fluid flow rate estimated value one-tenths of real recordings.

Table 12 Fluid-to-Fluid heat exchanger component sizing in Scenario B

\begin{tabular}{|c|c|c|c|c|}
\hline & $\begin{array}{l}\text { Loop Supply } \\
\text { Side Design } \\
\text { Fluid Flow Rate } \\
\text { [m3/s] }\end{array}$ & $\begin{array}{l}\text { Loop Demand } \\
\text { Side Design Fluid } \\
\text { Flow Rate [m3/s] }\end{array}$ & $\begin{array}{l}\text { Heat Exchanger U-Factor } \\
\text { Times Area Value [W/C] }\end{array}$ & $\begin{array}{l}\text { Loop-to-loop Temperature } \\
\text { Difference Used to Size Heat } \\
\text { Exchanger U-Factor Times } \\
\text { Area Value [C] }\end{array}$ \\
\hline $\begin{array}{r}\text { HX-5 (Base } \\
\text { Model) }\end{array}$ & 0.0008 & 0.0008 & 648.07 & 19 \\
\hline $\begin{array}{r}\text { [1] } \mathrm{HX}-5 \\
\text { (Flow rate } \\
\text { Adjustment) }\end{array}$ & 0.008 & 0.008 & 6480 & 19 \\
\hline
\end{tabular}


At the Facility level, demand End Use components are compared to the baseline model. With ten times higher flow rate in fluid-fluid heat exchanger flow rate, according to Figure 41, pump power usage of condenser loop would demand ten times more power.

This assumption makes data centers cooling coil rate about $700 \mathrm{~W}$ higher than the baseline. Larger pump power usage and larger sized heat exchanger, reduced zone air temperature surprisingly lower, when for by this assumption more than $40 \%$ of year set point temperature is met without powering refrigeration cycles in neither chiller nor heat pump.

Regards to Figure 42, there are times that zone means air temperature exceeds $23^{\circ} \mathrm{C}$ between late May to September (light green zone). However, still, for most of the year, the average temperature remains between the recommended temperature zone for data centers range, ruled by ASHRAE. There are only a few days that this temperature is not within recommended and passes $27^{\circ} \mathrm{C}$ (passing light green zone). Therefore, utilization of backup chiller or heat pump is not required for most of the year as it is relative to the claimed condition of the status quo.

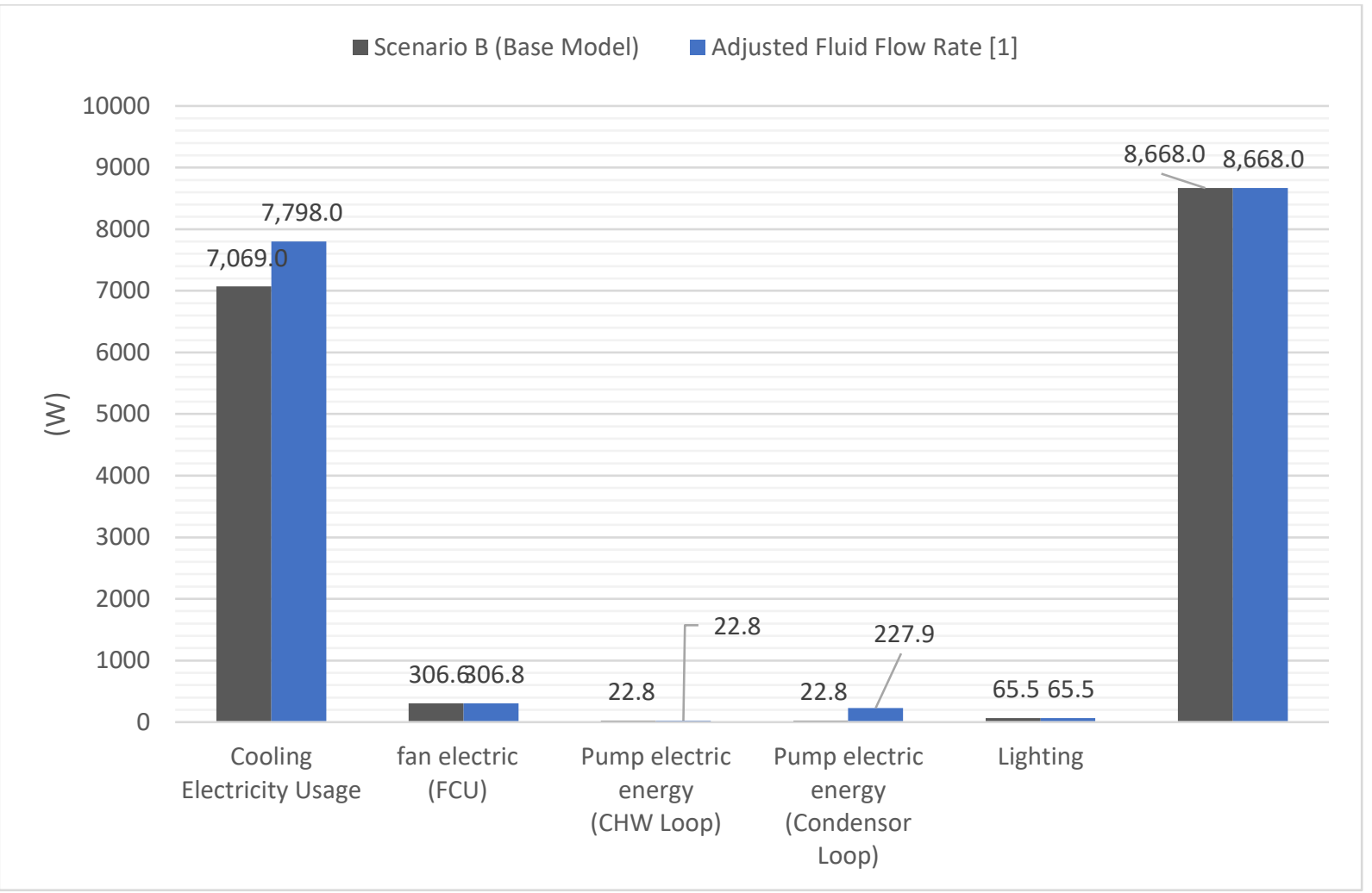

Figure 41 Component summary end- use (effect of heat exchanger fluid flow rate) 


\section{Mean Air Temperature $\left({ }^{\circ} \mathrm{C}\right)$}

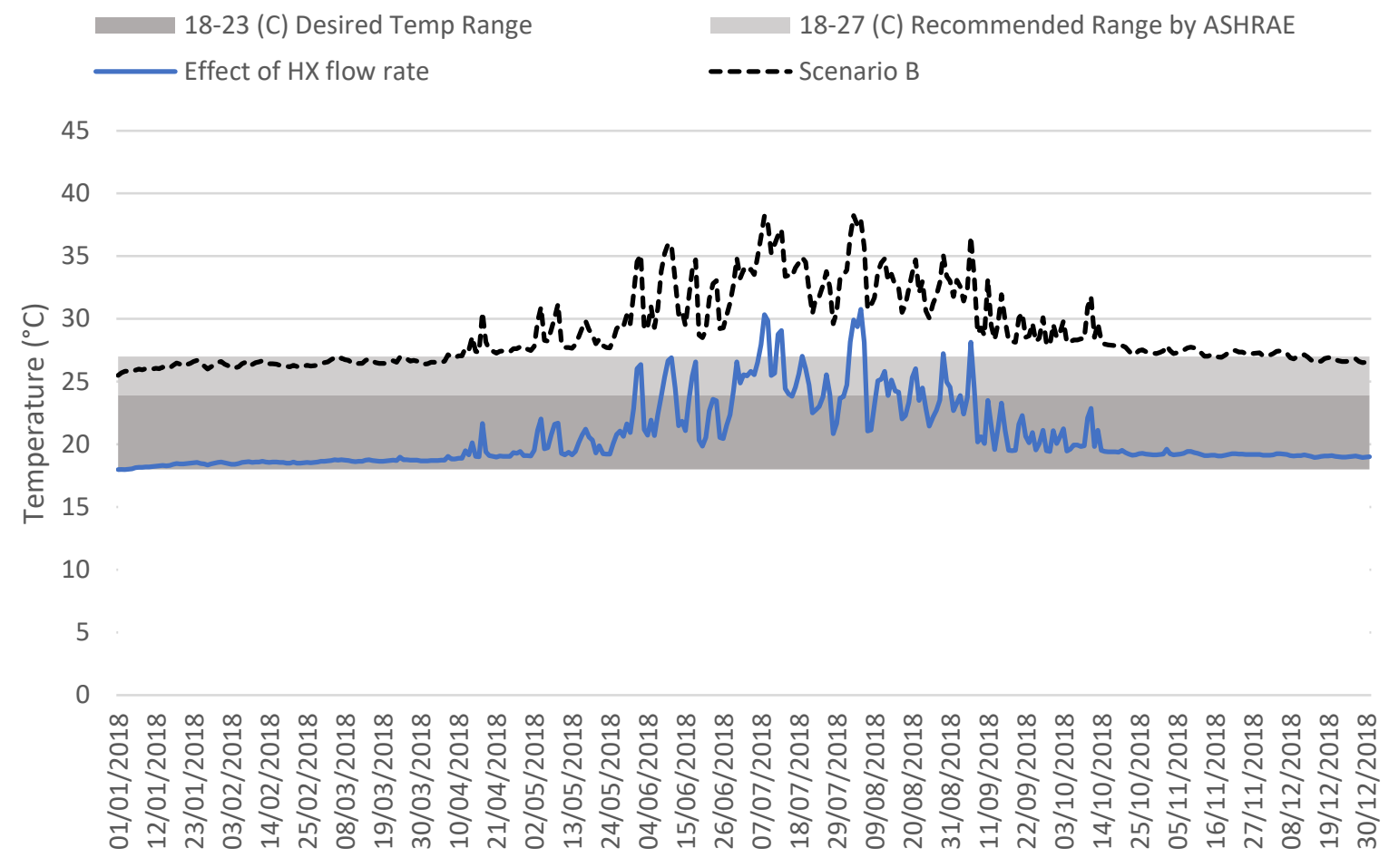

Figure 42 Effect of heat exchanger fluid flow rate on zone mean air temperature.

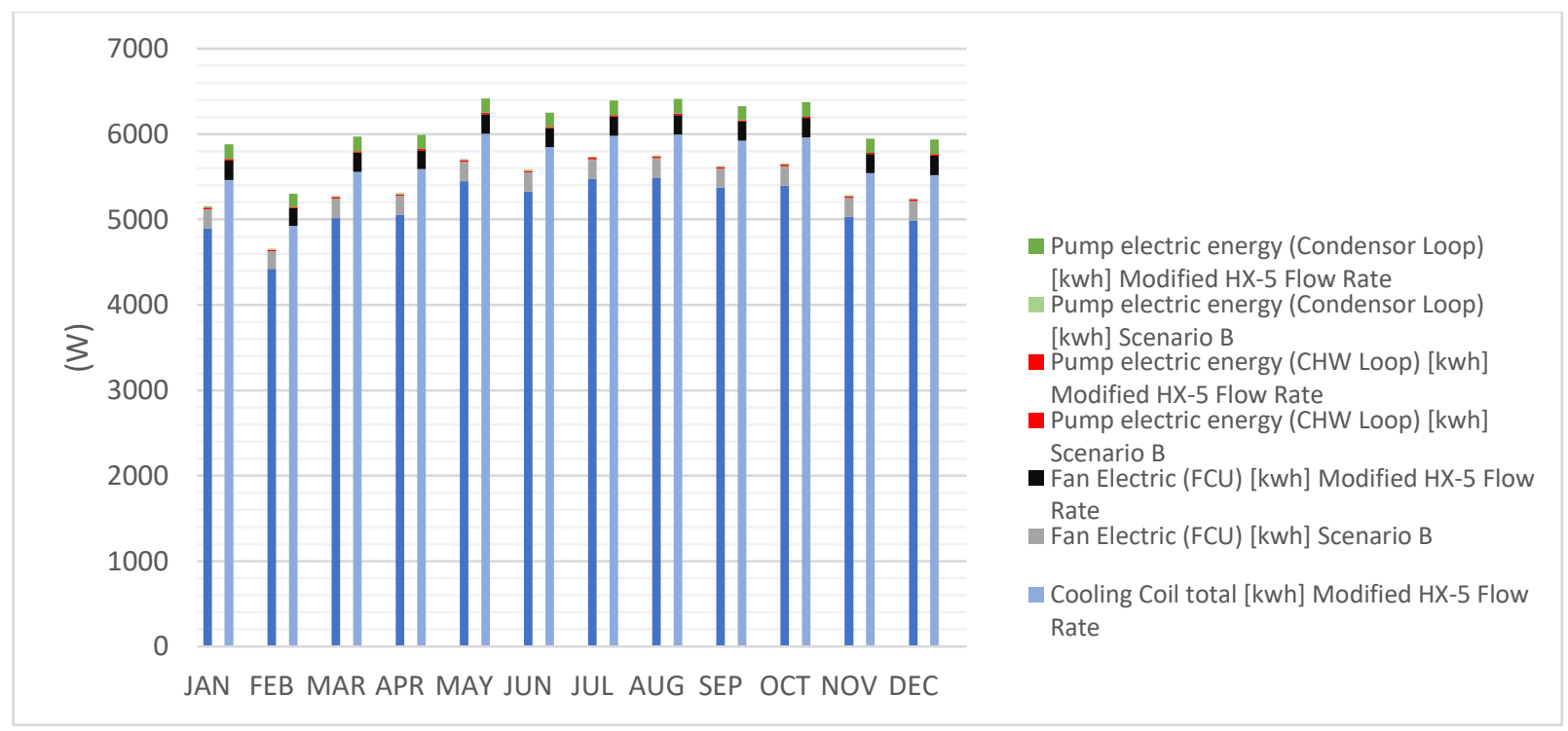

Figure 43 Monthly cooling energy rate in Scenario B and altered flow rate model.

By increasing the flow rate of the fluid $\mathrm{n}$ heat exchanger, zone coils can extract more energy from the zone (refer to Figure 43). May to Oct, the highest rate is depicted where it drops about $1000 \mathrm{~W}$ lower in February in both cases. 
The analysis showed that, by consuming 30\% more energy in the HVAC system, relative to baseline energy consumption (about $1.5 \mathrm{kw}$ ), average zone mean air temperature reduced from 28.9 (base model) to 20.6 (i.e. $28 \%$ average temperature drop is obtained). (Refer to Appendix C)

This alteration, increased $1453 \mathrm{kwh}$ to total zone cooling electricity consumption. Including, fans and pump). Whereas, when heat pump where used (Scenario A), more than eight times electricity consumption was needed to achieve almost the same result. Appendix $\mathrm{C}$ has covered a complete comparison between proposed scenarios and their resulting use of electricity and temperature variations.

\subsection{Effects of Perforated Tiles}

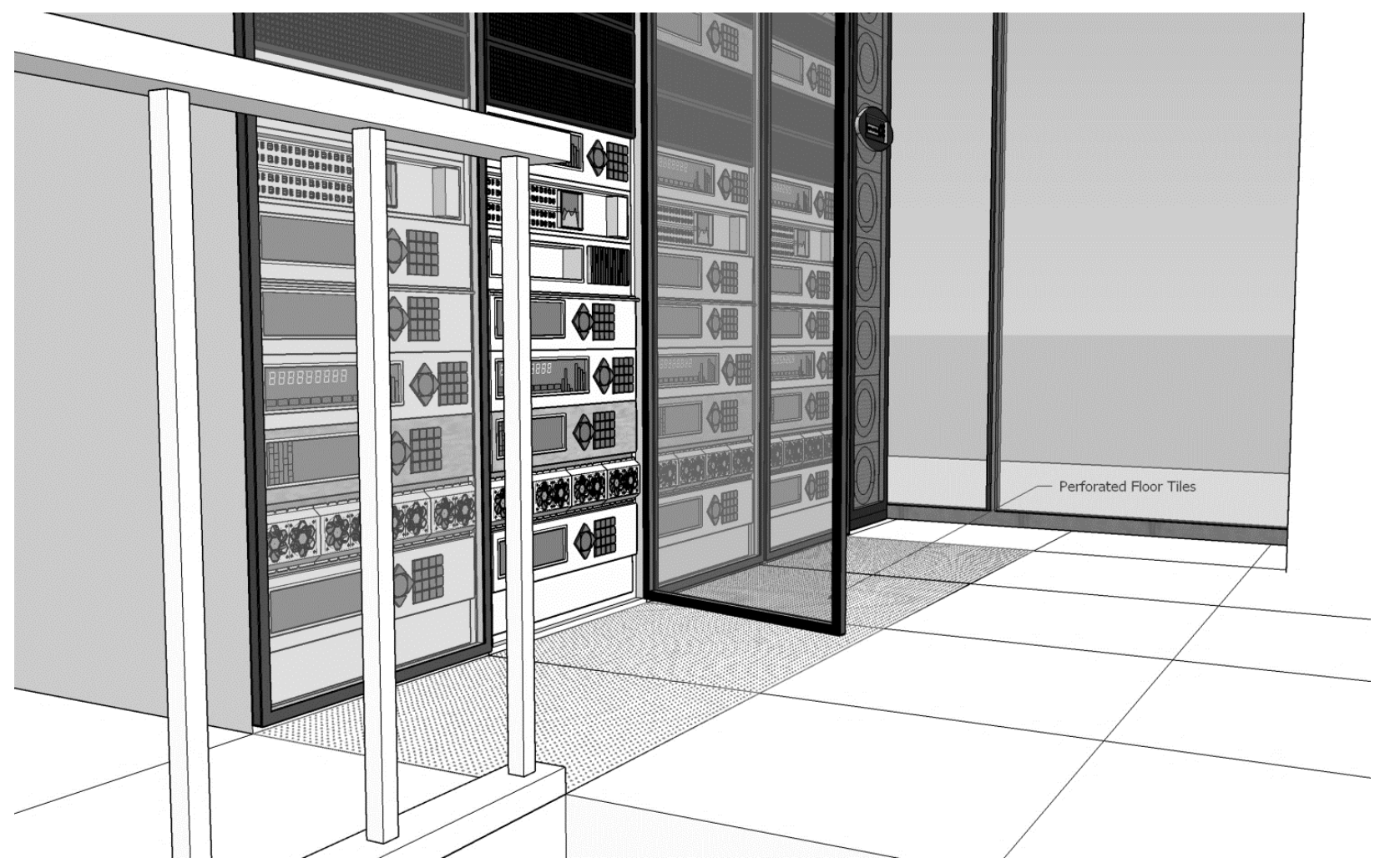

Figure 44 Illustrated perforated tiles in the 3D model.

As previously mentioned, cabinet racks are located on top of a $2 \mathrm{ft}$ raised floor area used to be the path for supply air stream and an area for hiding cables. Limited times throughout the year in hot summer days, when the backup cooling system is required, the air still use its old days path and passes through perforated tiles to cool the zone air. There are four perforated tiles aligned in front of the cabinets. (Figure 44) 
In the base model, the raised floor area is considered as "plenum space" with no air conditioning. The floor of the server room is covered with rectangular acoustic tiles with metal framing (high heat conductivity).

Second major validation property is integrating area equals surface area of perforated tiles, with similar characteristics and assumed $20 \%$ openings. Fluid Flow rate is consistent at $0.0008 \mathrm{~m}^{3} / \mathrm{s}$ same as the base model.

Results showed $2 \%$ reduction in mean air temperature of the zone, while, 102 kwh less energy was consumed. The effect is minimal but it leads the model one step closer to its temperature target.

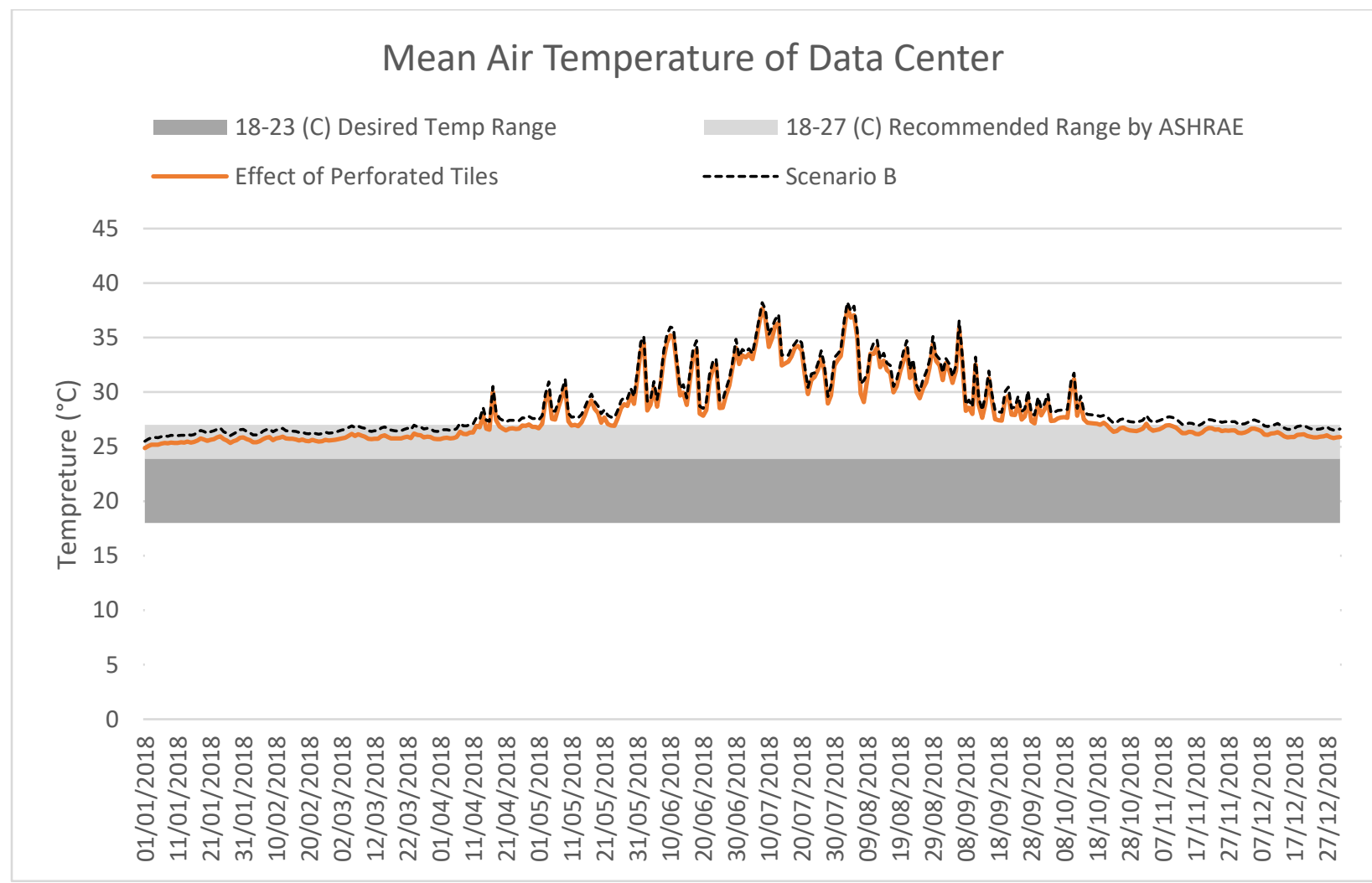

Figure 45 Effect of application of perforated tiles on zone mean air temperature. 


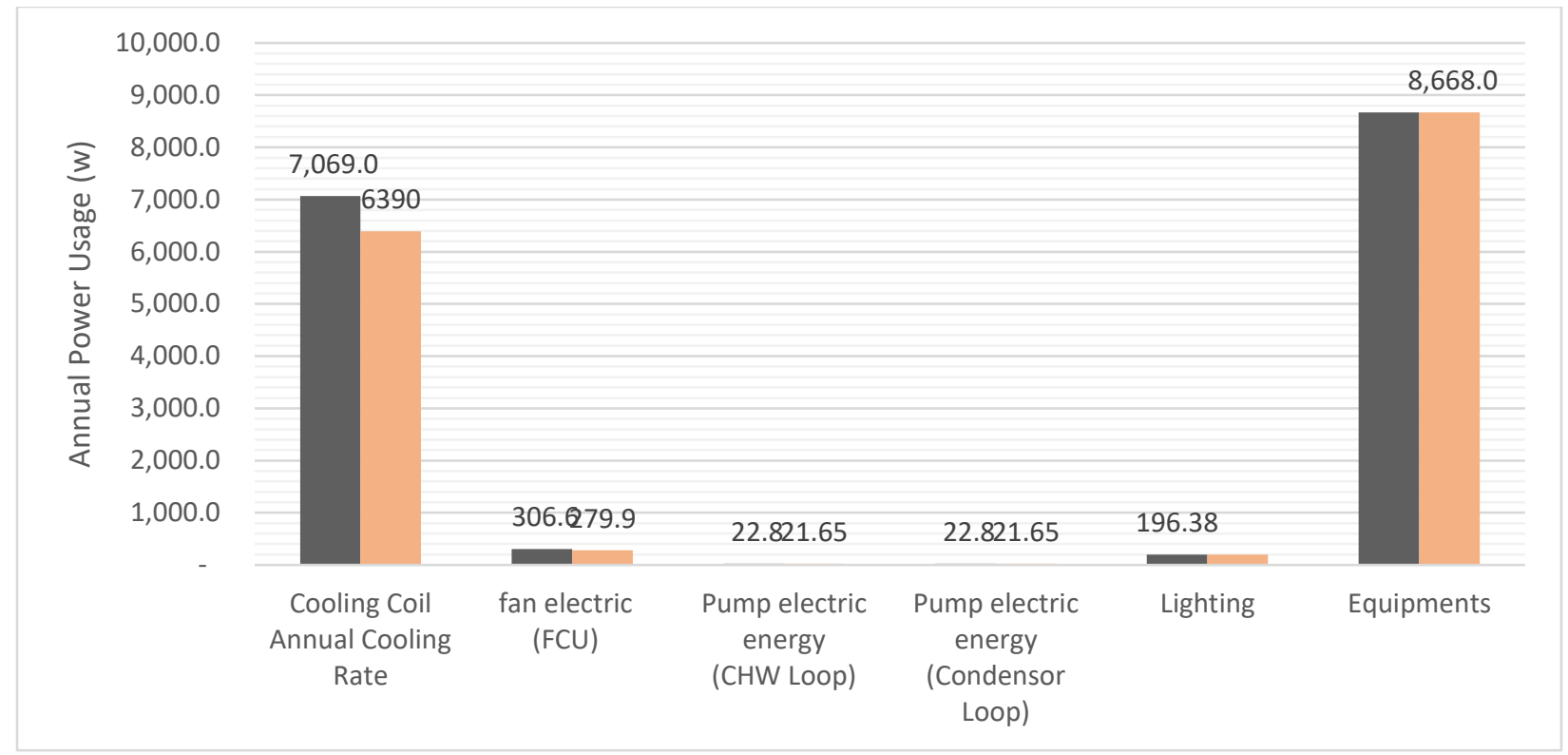

Figure 46 Component summary end - use (effect of applied perforated tiles)

Dash line represents components end use in base model (Scenario B). With consideration of perforated tile effect in the model, annual cooling coil would rate slightly lower than base model and less electricity usage is expected while, cooling coils have not possessed adequate power to meet peak cooling demand rates.

It was expected that floor tiles would have noticeable adverse effect on the overall performance of the data center's zone. However, poor floor material resistance on its own, acts not very different than floor tiles with perforations. And increase of heat loss through floor had positive effect on Zone air temperature. 


\subsection{Heat Exchanger Temperature Verification}

Water temperature coming from the ground heat exchangers are what dictates internal temperature range of the zone. Since fluid bypass the heat pump, the water temperature would fluctuate only as a matter of either ground temperature range or heat gain from pumps or other miscellaneous parameters. Following graphs are the method chosen to validate results of the final model (i.e. free cooling base model calibrated with fluid flow rate adjustment and connection of raised floor plenum). Appendix A well illustrates node labels corresponding with Figure 47.

Simulation is carried out over summer design week (Figure 47-lower image) and compared to actual collected data over the same period.

Results show water temperature entering heat exchanger fluctuates mostly between $17-25^{\circ} \mathrm{C}$ in the actual case study, while, it peaks to average $30^{\circ} \mathrm{C}$ in summer afternoons in our model. A very similar trend of TS80 (Demand-Inlet) and TS83 (Supply-Inlet) shows high efficiency and slight heat loss in the heat exchanger. Which resulted graph from the DesignBuilder model follows a similar pattern.

The reason behind the constant temperature difference in model result is, the data center is assumed to have constant $24 / 7$ workload but, in recorded data, returning fluid peaks up to $35^{\circ} \mathrm{C}$. This is resulted from influence merging fluid returning from other zones of the building to the heat exchanger unit in order to transfer excessive heat to the ground. 
HX Node Temperature Frequency- Summer Design Week (ERC Recordings)

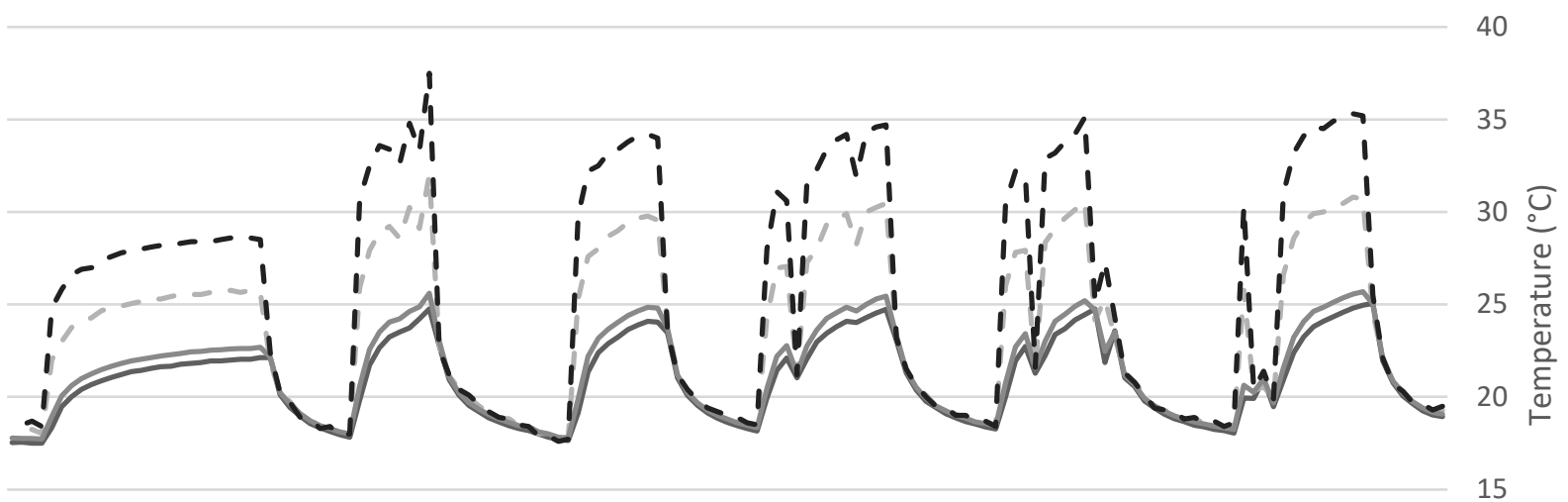

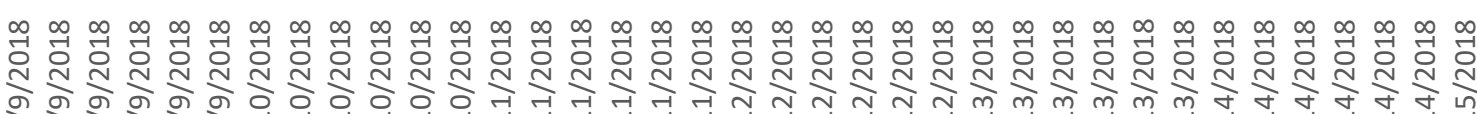
হᄒ হ হ

HX5_TRFRT_TS80 - - - HX5 TRFST_TS81

HX5_SWST_TS82 - - HX5_SWRT_TS83

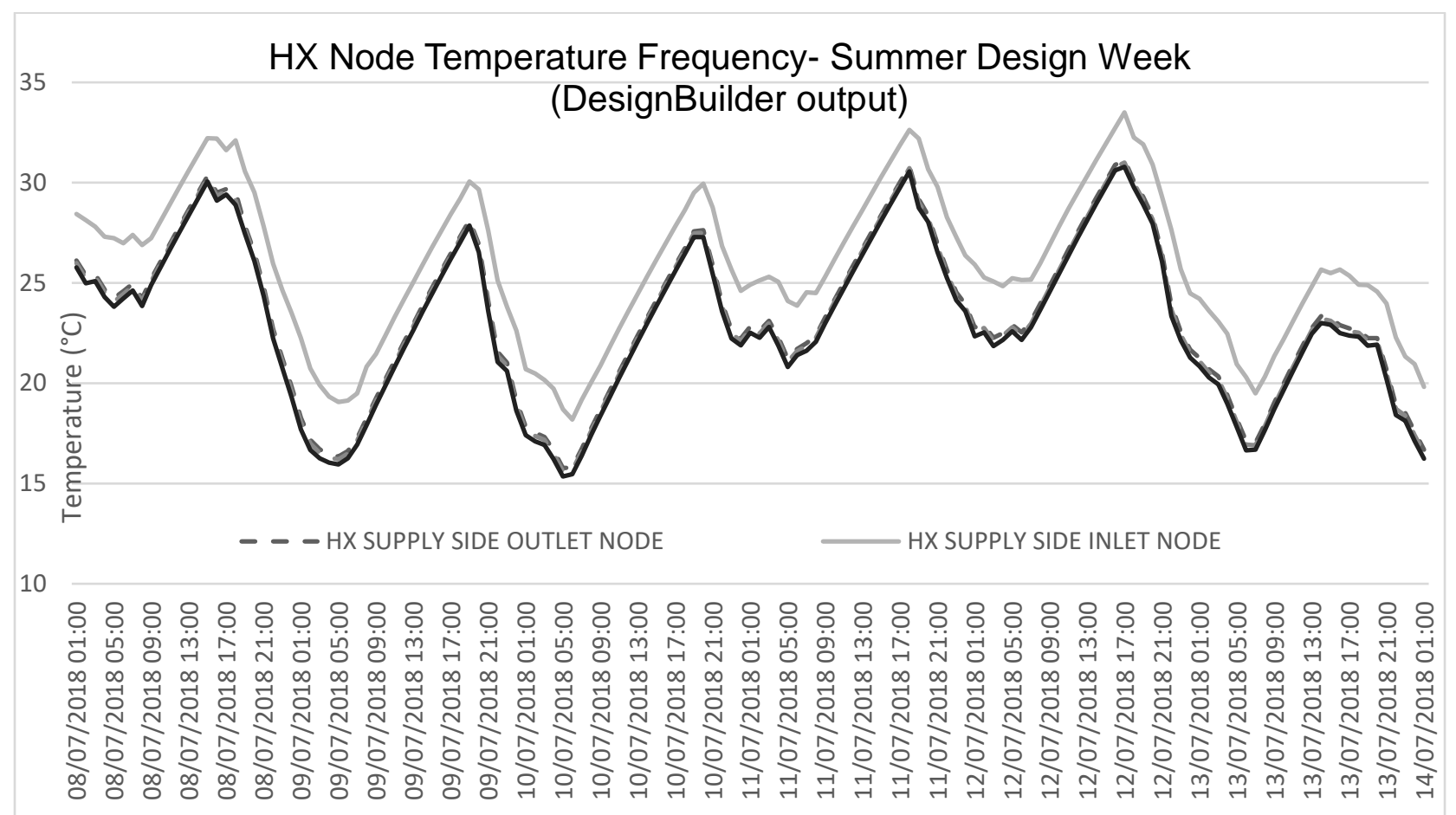

Figure 47 Verifying HX-5 Recorded Temperature Frequency - Summer Design Week 


\subsection{Annual Zone Performance}

As a result, thermal performance behaviour of three proposed scenarios with HVAC configuration variation is illustrated in Figure 48 (top image). Recommended temperature range is highlighted throughout the year for clear understanding. Darker green shade represents the desired zone temperature by data center operator. Which has achieved by both Scenario $A$ and Scenario B. It is clear that heat pump integration in both cases contributes to performance optimization. Although a considerable amount of energy required in both cases compared to Scenario B.

The highlighted area in lighter green represents upper end recommended zone air temperature by ASHRAE 2017. Scenario B, continuously remained in this zone during winter time, as ground temperature is well below the desired supply temperature. However, Summer pattern shows defectiveness of the model performance.

Lower graph (Figure 48), presented the effectiveness of proposed calibration methods on zone air temperature. Integration of perforated tiles as the realistic feature had an only slight positive effect (less than $1^{\circ} \mathrm{C}$ ) on overall performance. But combining two methods leads to similar desired model performance of the zone.

According to DC operators' claim, data center operates with limited need to chiller/ heat pump in summer and runs on almost free heat transfer by use of ground heat exchangers. The final energy model proposed by this research was successful in developing and introducing a model performing close to the actual case study. Further analysis and calibration measures would help to achieve even more accurate model.

In following section, the performance of all scenarios is investigated in terms of their use of electric energy. 
DC Mean Air Temperature $\left({ }^{\circ} \mathrm{C}\right)$

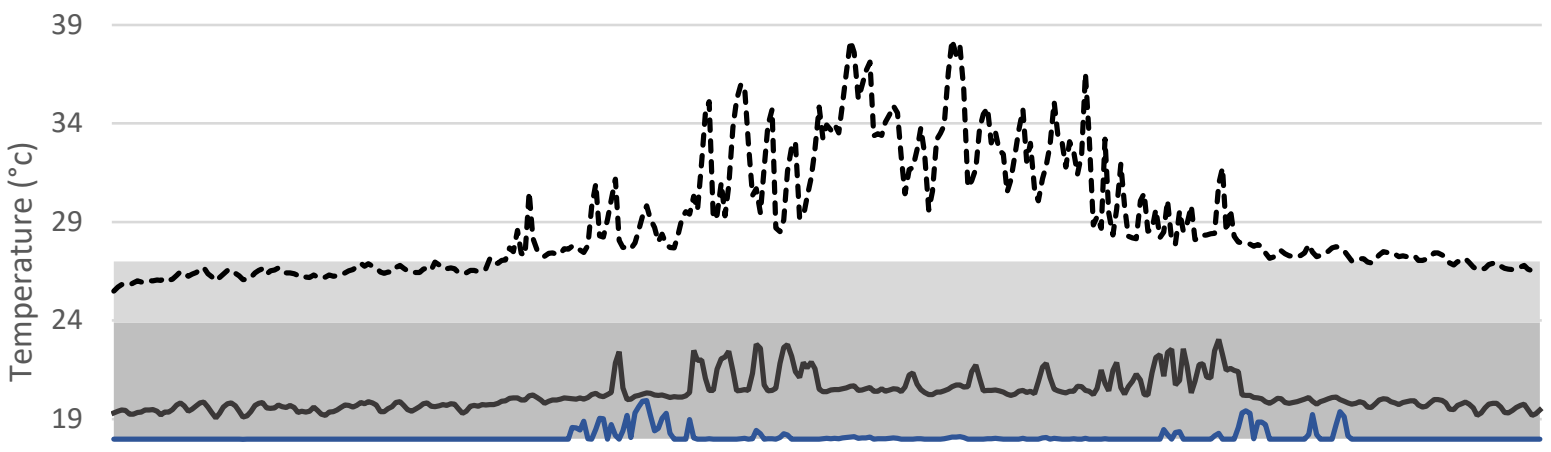

14

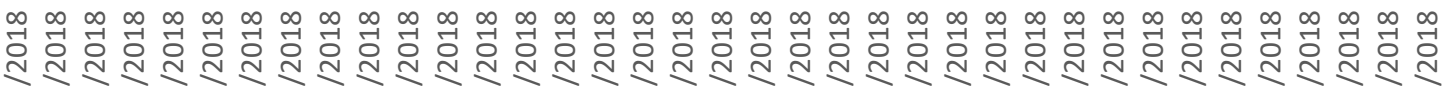

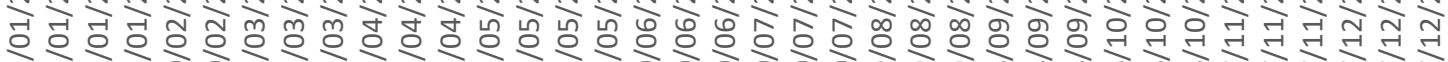

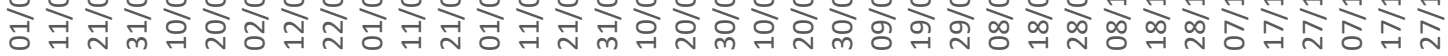

18-23 (C) Desired Temp Range

18-27 (C) Recommended Range by ASHRAE

--n--scenario B

Scenario A- GSHP

Scenario C - HX-HP

DC Mean Air Temperature $\left({ }^{\circ} \mathrm{C}\right)$

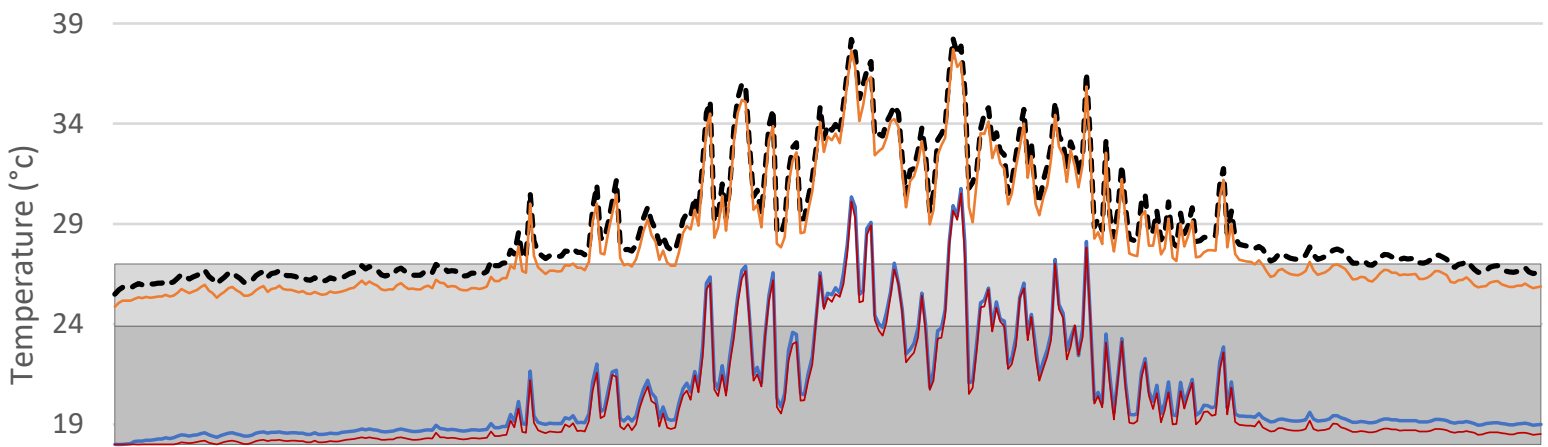

14

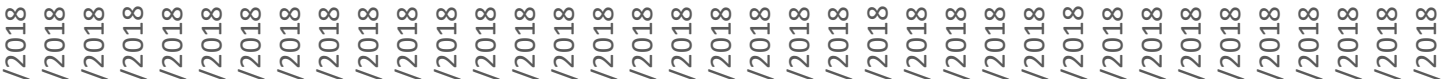

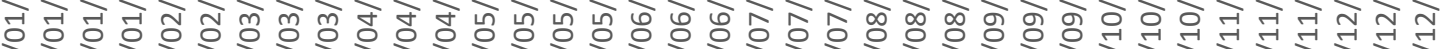

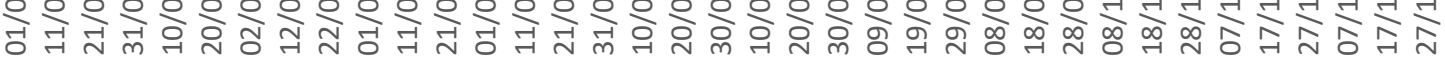

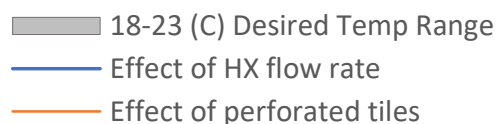

$\square$ 18-27 (C) Recommended Range by ASHRAE

Effect of perforated tiles

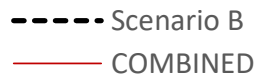

Figure 48 Effect of reviewed proposed calibration methods relative to the base model (scenario B) 
End-use electricity consumption among all scenarios and calibration methods are evaluated and summarised with comparison basis. In Table 13detailed comparison between all variations have been made to depict the deviation percentage between different scenarios.

For easier comparison, Table 13 described each scenario with one of the alphabetic. Brief description of each abbreviation is stated as follows,

- Scenario A: Ground Source Heat Pump (BASELINE)

- Scenario B: Direct connection of FCU and heat exchanger (free cooling)

- Scenario C: Parallel HX-HP connection (priority base)

- Scenario B - [1]: Adjustments applied to the fluid flow rate

- Scenario B - [2]: Plenum connection via perforated tiles

- Scenario B-B: combined calibrated model

Table 13 Comparative Evaluation of End-use Electric Consumption Among Proposed strategies

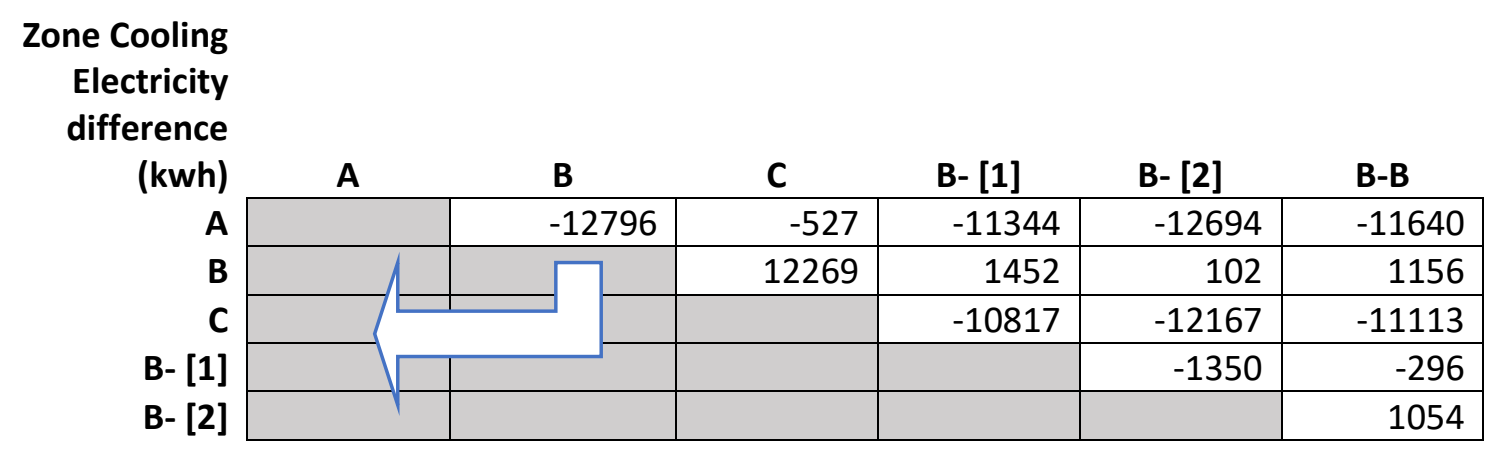

\begin{tabular}{|c|c|c|c|c|c|c|}
\hline $\begin{array}{r}\text { one Cooling } \\
\text { Electricity } \\
\text { Deviation }\end{array}$ & A & B & C & B- [1] & B- [2] & B-B \\
\hline A & & $-74 \%$ & $-3 \%$ & $-65 \%$ & $-73 \%$ & $-67 \%$ \\
\hline B & & 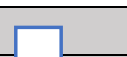 & $268 \%$ & $32 \%$ & $2 \%$ & $25 \%$ \\
\hline C & & & & $-64 \%$ & $-72 \%$ & $-66 \%$ \\
\hline B- [1] & & & & & $-22 \%$ & $-5 \%$ \\
\hline B- [2] & & & & & & $23 \%$ \\
\hline
\end{tabular}




\subsection{Conclusion}

Data centers are one of the significant energy-consuming sectors worldwide with almost $1.5 \%$ consuming rate of worldwide electricity. With the growing trend of energy use by these facilities, any steps towards more efficient facilities with optimized infrastructures are well appreciated.

This research is a case study of energy model development of a data center in DesignBuilder energy simulating software. A methodology has been developed to identify system configurations that suit a small data center like Earth Rangers. This study aimed, firstly, to develop a reliable energy model that can assist data centers operator and fellow researchers having an insight on performance evaluation of different HVAC system configuration. Secondly, to identify methods of validating the model that represents current data centers status.

Three HVAC configuration was introduced and investigated in this study. Similarities had been identified among baseline model performance and ERC's data center status quo. However, in order to obtain more realistic results, two calibration strategy was implemented. Baseline model performs cooling of the data center zone by in-zone fan coil unit connected to ground source heat exchangers as a heat sink.

The calibrated energy model was succeeded to achieve $10.7 \mathrm{~kW}$ cooling demand and $7.69 \mathrm{~kW}$ cooling output rate, comparing to 10.6 and $7.6 \mathrm{~kW}$ in the actual case, respectively. Results showed developed energy model obtains zone air temperature below $23^{\circ} \mathrm{C}$ in winter and remains below the upper limit of $27^{\circ} \mathrm{C}$ for most of the summer season. Calibration methods adjusted fluid flow rate, and integration of plenum underfloor area, reduced zone mean temperature from $29.9^{\circ} \mathrm{C}$ to $20.3^{\circ} \mathrm{C}$, while $67 \%$ less energy is needed relative to the scenario with heat pump use.

Implementation of a heat pump in two scenarios showed effective cooling results. Zone temperature was remained within the desired zone $\left(18-23^{\circ} \mathrm{C}\right)$ year-round. Although, this costs $11 \mathrm{kwh}$ more electricity uses for cooling compares to the final calibrated model. Whereas, the final calibrated model could lower indoor temperature to average $20.3^{\circ} \mathrm{C}$ with minimum electricity consumption.

Power Usage Effectiveness (PUE) value of modelled data center calculated 1.24 when the heat pump is in use, and it can be as efficient as 1.04 in value were a heat pump, and chiller is not being used. Results show the value of free cooling with the implementation of ground heat exchangers in cold climates. 
Validating results through recorded temperature tend of heat exchanger's nodes, shows simulated model, was succeeded to simulate similar pattern relative to recorded data. However, a slightly different trend in fluid returning to heat exchanger from the building proves the contribution of other zones in excessed fluid temperature. In order to achieve more accurate energy model, further investigation is required regards to identification and implementation of effective loads from other zones of Earth Rangers Centre.

\subsection{Future Works}

The results of this research lay the foundations for further related research projects. The research up to this point can be the starting point for the following topics:

- Identifying extra validation measures to enhance the energy model performance to the point can be used as a predicting machine for future developments

- feasibility of reuse of waste heat in either domestic heating or water heating application

- feasibility of using heat pump ASHP to achieve higher grade waste heat in Earth Rangers or neighbouring buildings

- Investigating expansion opportunities of this case study and evaluating the thermal performance of data center zone with a free cooling application

- feasibility of implementation of machine learning in such data center facilities in order to obtain a high accuracy rate for future performance prediction of a data center 


\section{Appendices}

\section{Appendix A - Fluid-to-Fluid Heat Exchanger Data Collection}

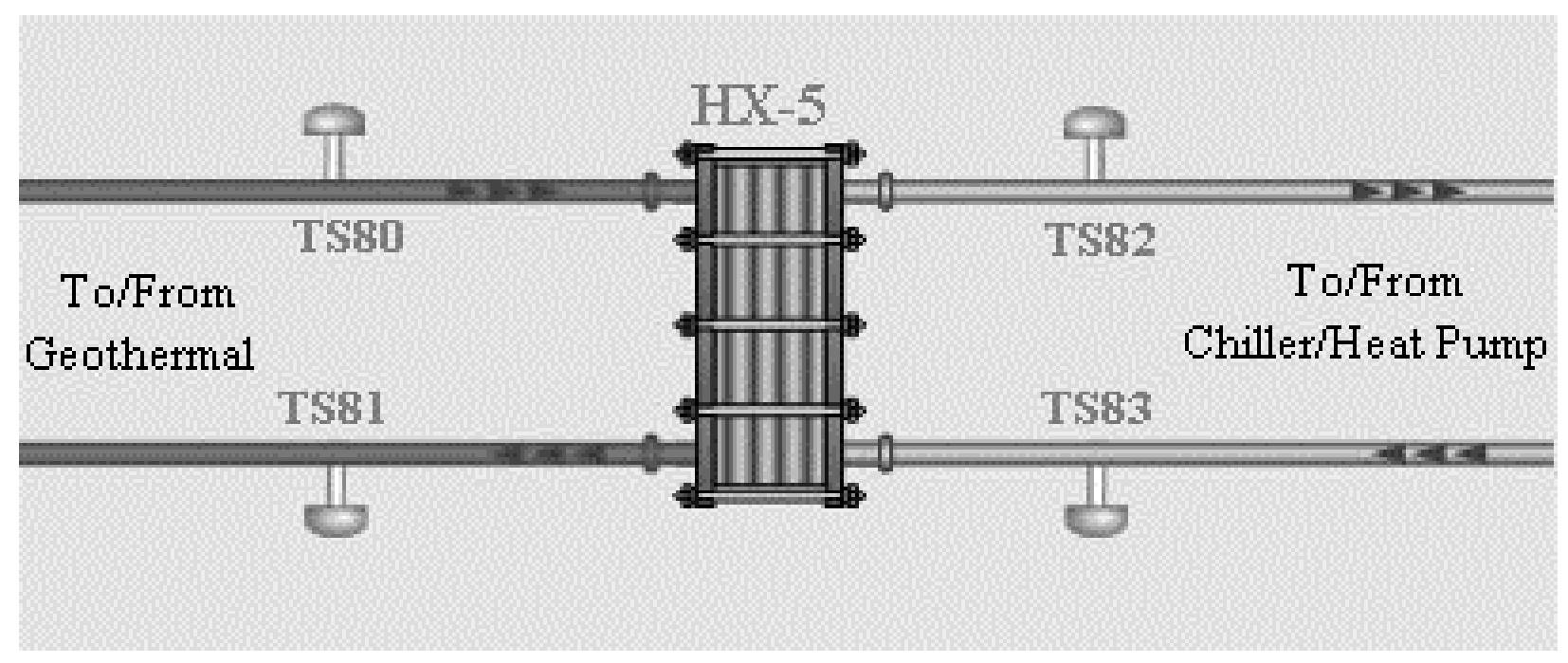

Figure 49 HX-5 heat exchanger connecting Geothermal to Chiller/Heat Pump

Following temperature, graphs are collected from building energy management records and presented separately relative to the demand / supply side (Figure 50). Node names collecting temperature recordings are presented in Figure 49. 

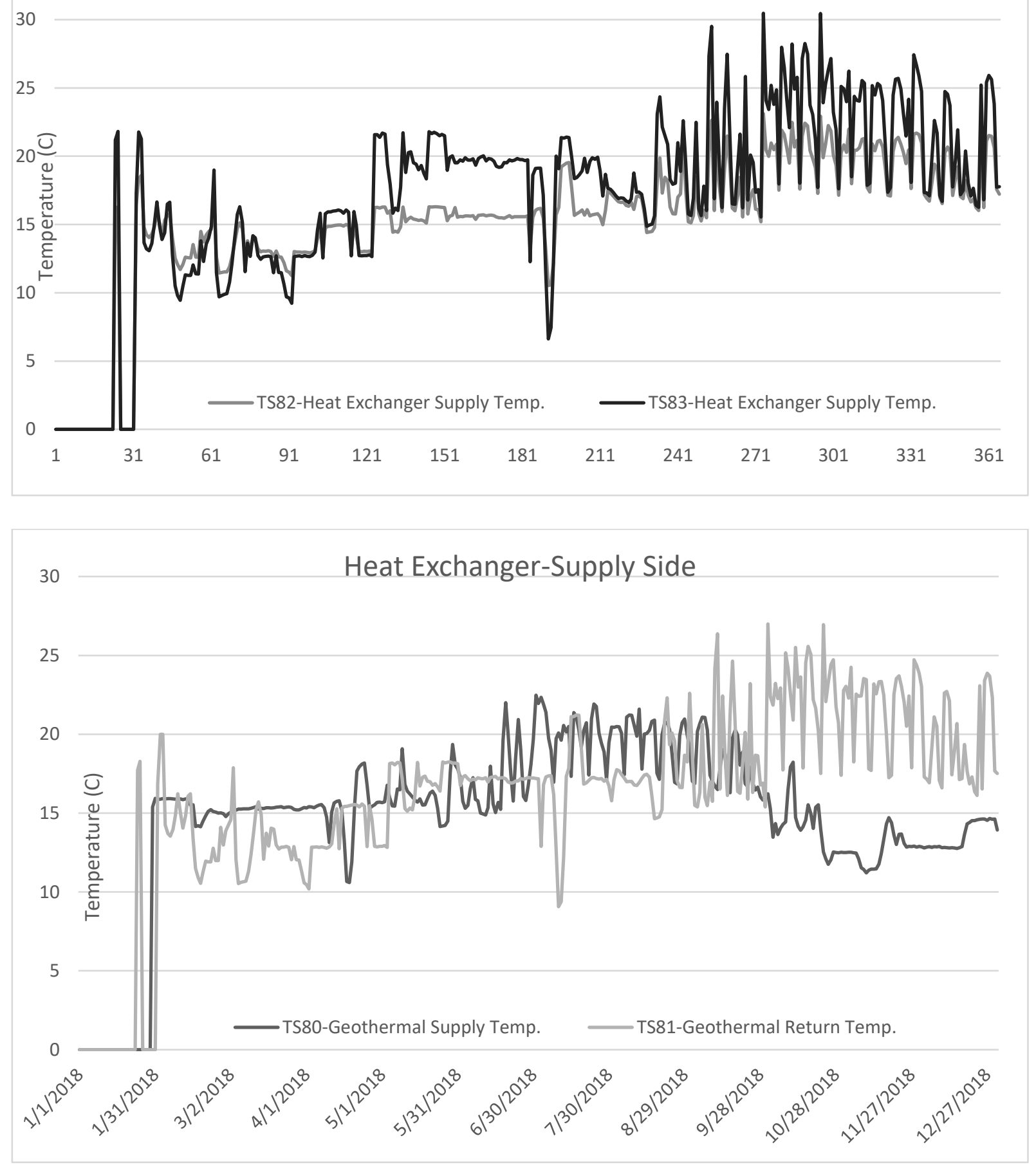

Figure 50 HX-5 input/output temperature records (2018) 


\section{Appendix B - Weather Data File}

\begin{tabular}{cc} 
Source & \multicolumn{2}{c}{ ASHRAE / WYEC } \\
Station & ON - Toronto Lester B. Pearson Int. \\
Climate Zone & $6 \mathrm{~A}$ \\
Latitude & $43.68^{\circ}$ \\
Longitude & $-79.63^{\circ}$ \\
Elevation $(\mathrm{m})$ & 173 \\
Standard Pressure $(\mathrm{kPa})$ & 99.3
\end{tabular}

Average Monthly Weather data $\left({ }^{\circ} \mathrm{C}\right)$

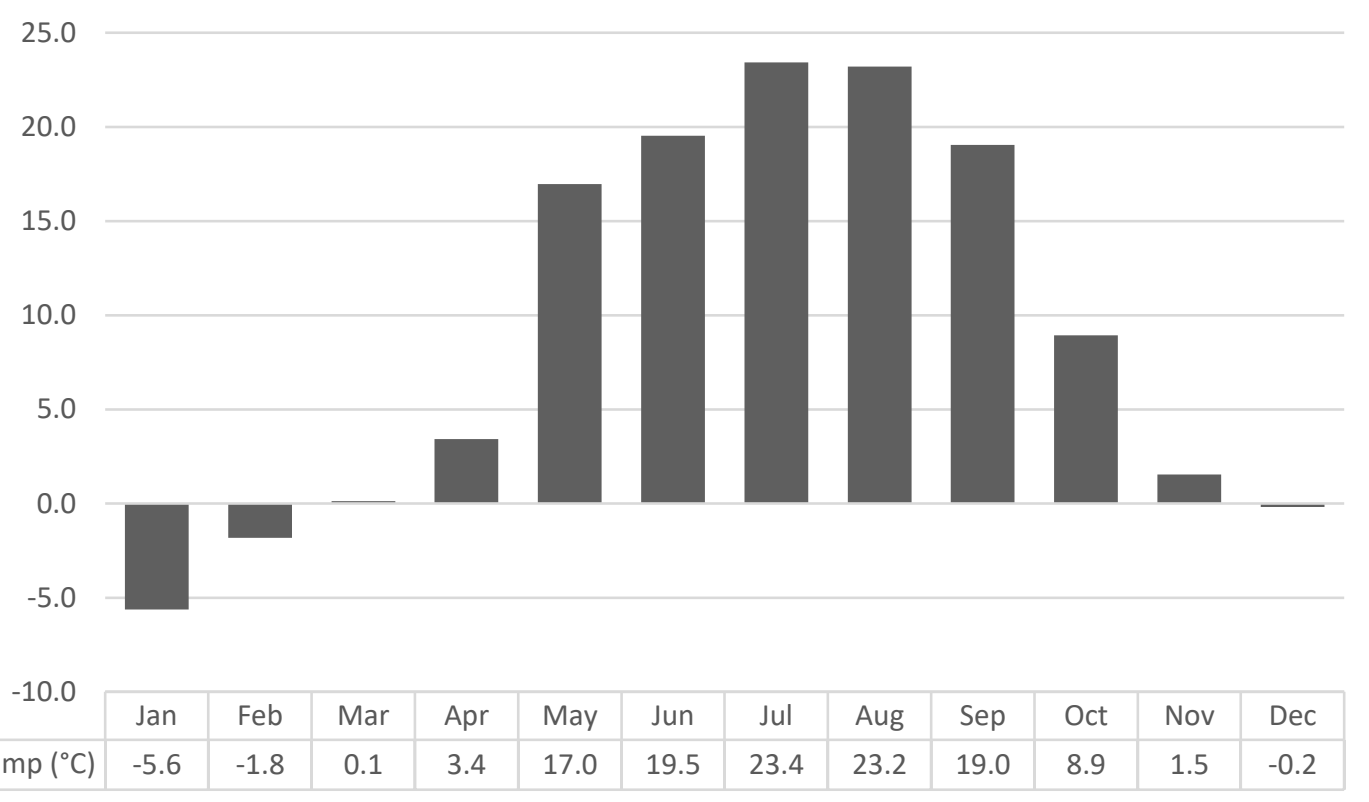

Figure 51 Monthly Weather Data - 2018 (Ref: http://climate.onebuilding.org) 


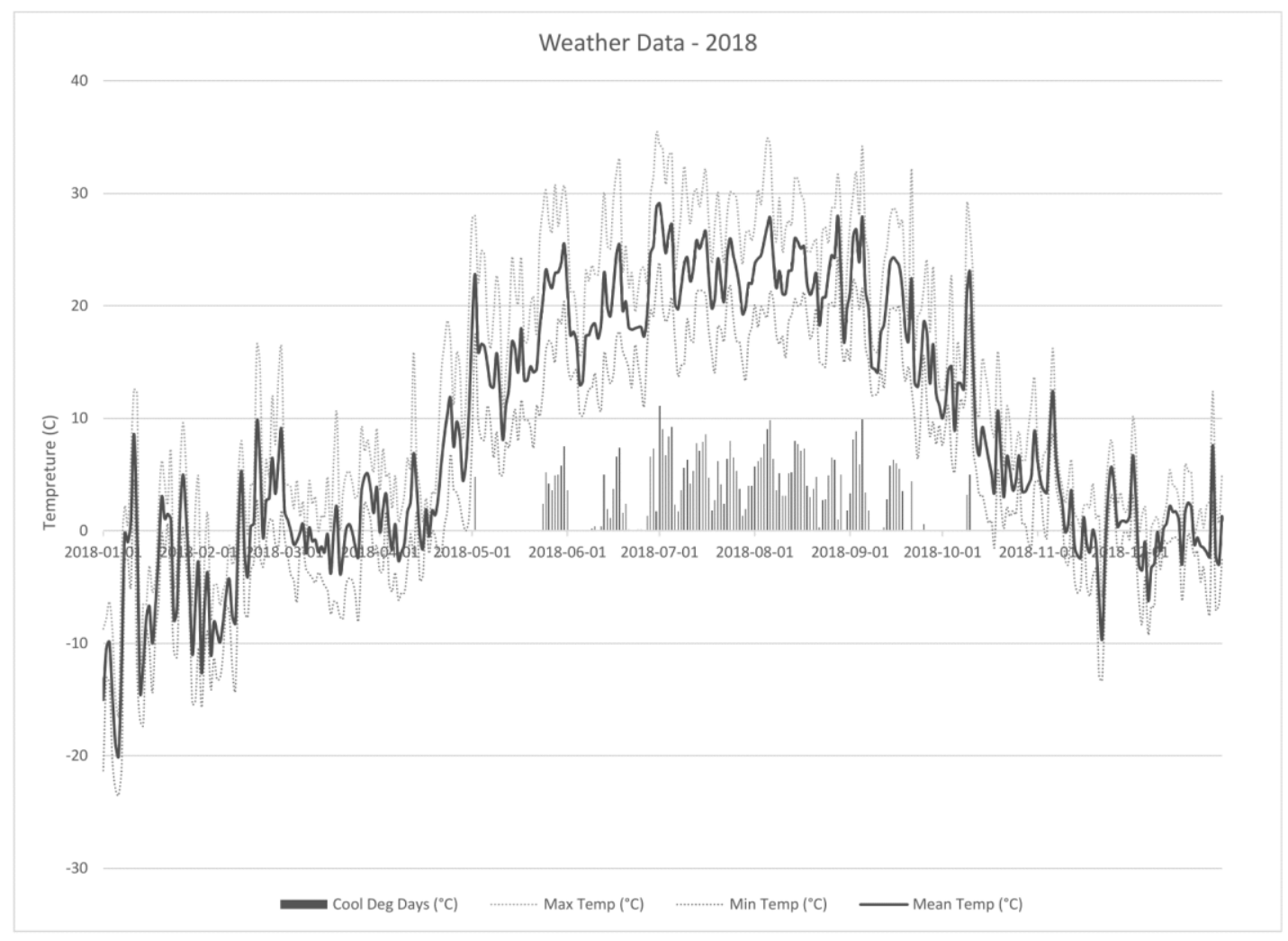

Figure 52 Daily Weather Data - 2018 (Data Source: http://climate.onebuilding.org)

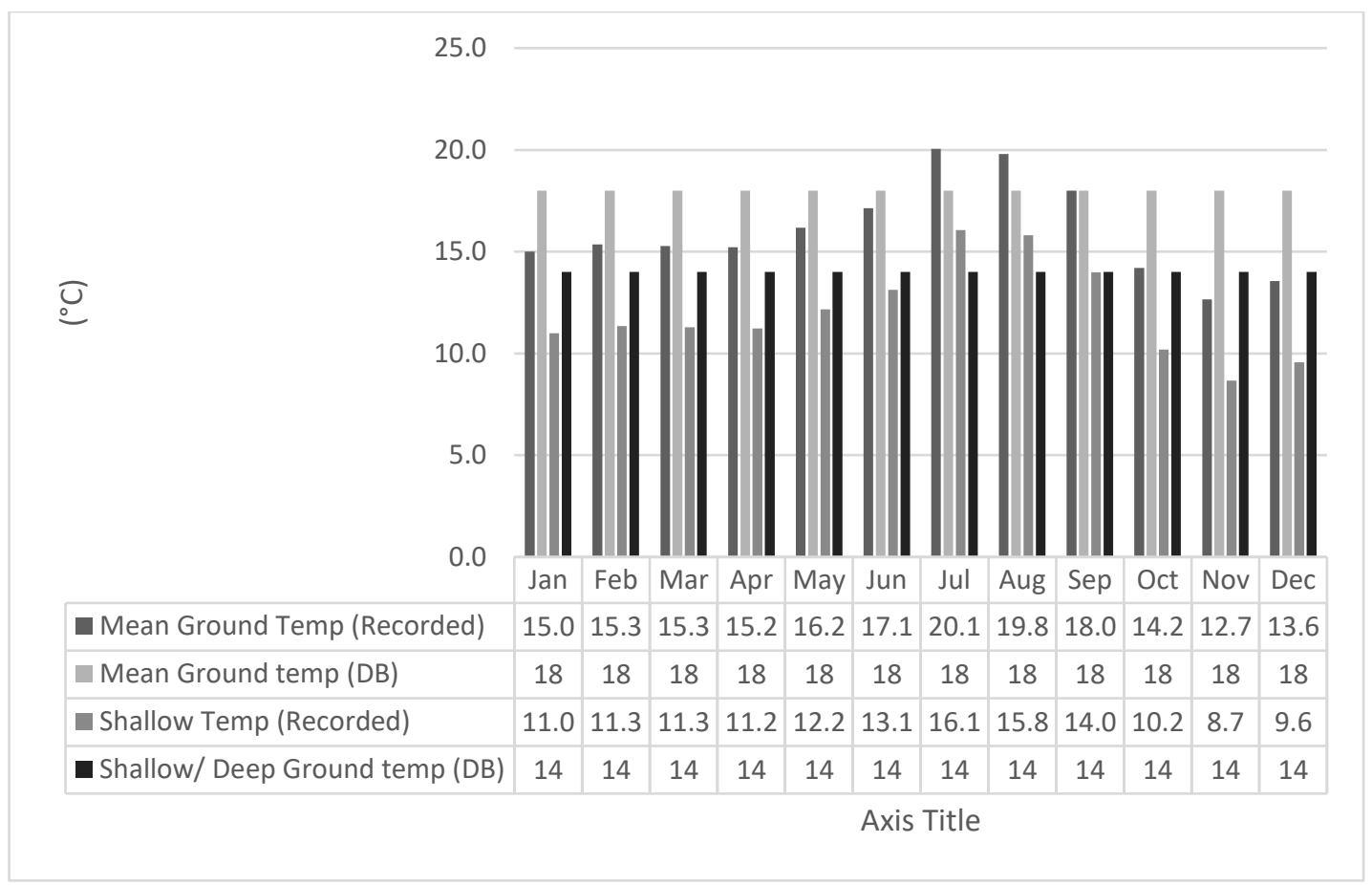




\section{Appendix C - Extra Calculations}

\begin{tabular}{|c|c|c|c|c|c|c|}
\hline & & & & & mperat & \\
\hline A & Heat $\mathrm{P}$ & & & A & & \\
\hline B & Fan Co & & & B & & \\
\hline C & Heat $\mathrm{P}$ & eat Excl & & C & & \\
\hline B-[1] & Adjuste & rate & & B-[1] & & \\
\hline B-[2] & $\begin{array}{l}\text { Plenum } \\
\text { Combir }\end{array}$ & & & B-[2] & & \\
\hline B-B & {$[2]$} & & & B-B & & \\
\hline $\begin{array}{l}\text { Mean } \\
\text { re }\left({ }^{\circ} \mathrm{C}\right)\end{array}$ & A & B & C & B-[1] & B-[2] & B-B \\
\hline A & & $37 \%$ & $10 \%$ & $12 \%$ & $35 \%$ & $11 \%$ \\
\hline B & & & $30 \%$ & $28 \%$ & $2 \%$ & $29 \%$ \\
\hline C & & & & $1 \%$ & $28 \%$ & $0 \%$ \\
\hline B-[1] & & & & & $26 \%$ & $1 \%$ \\
\hline B-[2] & & & & & & $28 \%$ \\
\hline B-B & & & & & & \\
\hline
\end{tabular}

Zone Cooling

Electricity

difference

\begin{tabular}{|c|c|c|c|c|c|c|}
\hline (kwh) & A & B & C & B- [1] & B- [2] & B-B \\
\hline A & & -12796 & -527 & -11344 & -12694 & -11640 \\
\hline B & & & 12269 & 1452 & 102 & 1156 \\
\hline C & & & & -10817 & -12167 & -11113 \\
\hline B- [1] & & & & & -1350 & -296 \\
\hline B- [2] & & & & & & 1054 \\
\hline B-B & & & & & & \\
\hline
\end{tabular}

\section{Zone Cooling}

Electricity

Deviation
A

B

C

B- [1]

B- [2]

B-B

\begin{tabular}{|c|c|c|c|c|c|}
\hline A & $-74 \%$ & $-3 \%$ & $-65 \%$ & $-73 \%$ & $-67 \%$ \\
\hline B & & $268 \%$ & $32 \%$ & $2 \%$ & $25 \%$ \\
\hline C & & & $-64 \%$ & $-72 \%$ & $-66 \%$ \\
\hline B- [1] & & & & $-22 \%$ & $-5 \%$ \\
\hline B- [2] & & & & & $23 \%$ \\
\hline B-B & & & & & \\
\hline
\end{tabular}




\section{Appendix D - Baseline Model Input}

Report: Annual Building Utility Performance Summary

For: Entire Facility

Values gathered over $\mathbf{8 7 6 0 . 0 0}$ hours

Site and Source Energy

\begin{tabular}{|l|r|r|r|}
\hline & $\begin{array}{r}\text { Total Energy } \\
\text { [kWh] }\end{array}$ & $\begin{array}{r}\text { Energy Per Total Building Area } \\
\text { [kWh/m2] }\end{array}$ & $\begin{array}{r}\text { Energy Per Conditioned Building } \\
\text { Area [kWh/m2] }\end{array}$ \\
\hline $\begin{array}{l}\text { Total Site } \\
\text { Energy }\end{array}$ & 87603.35 & 593.83 & 593.83 \\
\hline Net Site Energy & 87603.35 & 593.83 & 593.83 \\
\hline $\begin{array}{l}\text { Total Source } \\
\text { Energy }\end{array}$ & 277439.80 & 1880.66 & 1880.66 \\
\hline $\begin{array}{l}\text { Net Source } \\
\text { Energy }\end{array}$ & 277439.80 & 1880.66 & 1880.66 \\
\hline
\end{tabular}

\section{Building Area}

\begin{tabular}{|l|r|}
\hline \multicolumn{1}{|c|}{ Area [m2] } \\
\hline Total Building Area & 147.52 \\
\hline Net Conditioned Building Area & 147.52 \\
\hline Unconditioned Building Area & 0.00 \\
\hline
\end{tabular}

End Uses

\begin{tabular}{|c|c|c|c|c|c|c|}
\hline & $\begin{array}{r}\text { Electricity } \\
\text { [kWh] }\end{array}$ & $\begin{array}{r}\text { Natural Gas } \\
\text { [kWh] }\end{array}$ & $\begin{array}{r}\text { Additional Fuel } \\
\text { [kWh] }\end{array}$ & $\begin{array}{r}\text { District } \\
\text { Cooling [kWh] }\end{array}$ & $\begin{array}{r}\text { District } \\
\text { Heating [kWh] }\end{array}$ & $\begin{array}{r}\text { Water } \\
\text { [m3] }\end{array}$ \\
\hline Heating & 0.00 & 0.00 & 0.00 & 0.00 & 0.00 & 0.00 \\
\hline Cooling & 969.36 & 0.00 & 0.00 & 0.00 & 0.00 & 0.00 \\
\hline Interior Lighting & 3329.36 & 0.00 & 0.00 & 0.00 & 0.00 & 0.00 \\
\hline Exterior Lighting & 0.00 & 0.00 & 0.00 & 0.00 & 0.00 & 0.00 \\
\hline $\begin{array}{l}\text { Interior } \\
\text { Equipment }\end{array}$ & 79700.04 & 0.00 & 0.00 & 0.00 & 0.00 & 0.00 \\
\hline $\begin{array}{l}\text { Exterior } \\
\text { Equipment }\end{array}$ & 0.00 & 0.00 & 0.00 & 0.00 & 0.00 & 0.00 \\
\hline Fans & 3200.84 & 0.00 & 0.00 & 0.00 & 0.00 & 0.00 \\
\hline Pumps & 403.75 & 0.00 & 0.00 & 0.00 & 0.00 & 0.00 \\
\hline Heat Rejection & 0.00 & 0.00 & 0.00 & 0.00 & 0.00 & 0.00 \\
\hline Humidification & 0.00 & 0.00 & 0.00 & 0.00 & 0.00 & 0.00 \\
\hline Heat Recovery & 0.00 & 0.00 & 0.00 & 0.00 & 0.00 & 0.00 \\
\hline
\end{tabular}




\begin{tabular}{|l|r|r|r|r|r|r|}
\hline Water Systems & 0.00 & 0.00 & 0.00 & 0.00 & 0.00 & 0.00 \\
\hline Refrigeration & 0.00 & 0.00 & 0.00 & 0.00 & 0.00 & 0.00 \\
\hline Generators & 0.00 & 0.00 & 0.00 & 0.00 & 0.00 & 0.00 \\
\hline & & & & & & \\
\hline Total End Uses & 87603.35 & 0.00 & 0.00 & 0.00 & 0.00 & 0.00 \\
\hline
\end{tabular}

End Uses By Subcategory

\begin{tabular}{|c|c|c|c|c|c|c|}
\hline & 을 & 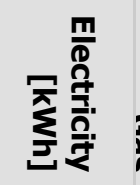 & 孞 & 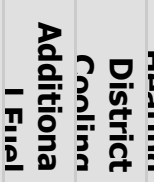 & 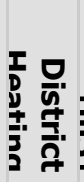 & 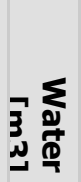 \\
\hline \multirow[t]{2}{*}{ Heating } & Boiler & 0.00 & 0.00 & 0.000 .00 & 0.00 & 0.00 \\
\hline & Boiler Parasitic & 0.00 & 0.00 & 0.000 .00 & 0.00 & 0.00 \\
\hline Cooling & General & 969.36 & 0.00 & 0.000 .00 & 0.00 & 0.00 \\
\hline \multirow[t]{6}{*}{ Interior Lighting } & ELECTRIC EQUIPMENT\#0Basement:Zone\#GeneralLights & 159.58 & 0.00 & 0.000 .00 & 0.00 & 0.00 \\
\hline & ELECTRIC EQUIPMENT\# 1 X1:ZoneA\#GeneralLights & 606.99 & 0.00 & 0.000 .00 & 0.00 & 0.00 \\
\hline & ELECTRIC EQUIPMENT\#1X1:ZoneC\#GeneralLights & 220.02 & 0.00 & 0.000 .00 & 0.00 & 0.00 \\
\hline & ELECTRIC EQUIPMENT\#1X1:ZoneB\#GeneralLights & 237.32 & 0.00 & 0.000 .00 & 0.00 & 0.00 \\
\hline & ELECTRIC EQUIPMENT\#1X2DC:DC\#GeneralLights & 573.44 & 0.00 & 0.000 .00 & 0.00 & 0.00 \\
\hline & ELECTRIC EQUIPMENT\#2:Zone1\#GeneralLights & 1532.01 & 0.00 & 0.000 .00 & 0.00 & 0.00 \\
\hline Exterior Lighting & General & 0.00 & 0.00 & 0.000 .00 & 0.00 & 0.00 \\
\hline \multirow[t]{5}{*}{ Interior Equipment } & ELECTRIC EQUIPMENT\#1X1:ZoneA\#05 & 840.00 & 0.00 & 0.000 .00 & 0.00 & 0.00 \\
\hline & ELECTRIC EQUIPMENT\#1X1:ZoneC\#05 & 304.48 & 0.00 & 0.000 .00 & 0.00 & 0.00 \\
\hline & ELECTRIC EQUIPMENT\#1X1:ZoneB\#05 & 328.42 & 0.00 & 0.000 .00 & 0.00 & 0.00 \\
\hline & ELECTRIC EQUIPMENT\#1X2DC:DC\#05 & 76107.03 & 0.00 & 0.000 .00 & 0.00 & 0.00 \\
\hline & ELECTRIC EQUIPMENT\#2:Zone1\#05 & 2120.11 & 0.00 & 0.000 .00 & 0.00 & 0.00 \\
\hline Exterior Equipment & General & 0.00 & 0.00 & 0.000 .00 & 0.00 & 0.00 \\
\hline Fans & General & 3200.84 & 0.00 & 0.000 .00 & 0.00 & 0.00 \\
\hline Pumps & General & 403.75 & 0.00 & 0.000 .00 & 0.00 & 0.00 \\
\hline Heat Rejection & General & 0.00 & 0.00 & 0.000 .00 & 0.00 & 0.00 \\
\hline Humidification & General & 0.00 & 0.00 & 0.000 .00 & 0.00 & 0.00 \\
\hline Heat Recovery & General & 0.00 & 0.00 & 0.000 .00 & 0.00 & 0.00 \\
\hline Water Systems & General & 0.00 & 0.00 & 0.000 .00 & 0.00 & 0.00 \\
\hline Refrigeration & General & 0.00 & 0.00 & 0.000 .00 & 0.00 & 0.00 \\
\hline Generators & General & 0.00 & 0.00 & 0.000 .00 & 0.00 & 0.00 \\
\hline
\end{tabular}




\section{Normalized Metrics}

Utility Use Per Conditioned Floor Area

\begin{tabular}{|c|c|c|c|c|c|c|}
\hline & $\begin{array}{r}\text { Electricity } \\
\text { Intensity } \\
{[\mathbf{k W h} / \mathbf{m} 2]}\end{array}$ & $\begin{array}{r}\text { Natural Gas } \\
\text { Intensity } \\
\text { [kWh/m2] }\end{array}$ & $\begin{array}{r}\text { Additional Fuel } \\
\text { Intensity } \\
\text { [kWh/m2] }\end{array}$ & $\begin{array}{r}\text { District Cooling } \\
\text { Intensity } \\
\text { [kWh/m2] }\end{array}$ & $\begin{array}{r}\text { District Heating } \\
\text { Intensity } \\
{[\mathrm{kWh} / \mathrm{m} 2]}\end{array}$ & $\begin{array}{r}\text { Water } \\
\text { Intensity } \\
{[\mathrm{m} 3 / \mathrm{m} 2]}\end{array}$ \\
\hline Lighting & 22.57 & 0.00 & 0.00 & 0.00 & 0.00 & 0.00 \\
\hline HVAC & 31.01 & 0.00 & 0.00 & 0.00 & 0.00 & 0.00 \\
\hline Other & 540.26 & 0.00 & 0.00 & 0.00 & 0.00 & 0.00 \\
\hline Total & 593.83 & 0.00 & 0.00 & 0.00 & 0.00 & 0.00 \\
\hline
\end{tabular}

\section{Utility Use Per Total Floor Area}

\begin{tabular}{|c|c|c|c|c|c|c|}
\hline & $\begin{array}{r}\text { Electricity } \\
\text { Intensity } \\
{[\mathbf{k W h} / \mathbf{m} 2]}\end{array}$ & $\begin{array}{r}\text { Natural Gas } \\
\text { Intensity } \\
\text { [kWh/m2] }\end{array}$ & $\begin{array}{r}\text { Additional Fuel } \\
\text { Intensity } \\
\text { [kWh/m2] }\end{array}$ & $\begin{array}{r}\text { District Cooling } \\
\text { Intensity } \\
\text { [kWh/m2] }\end{array}$ & $\begin{array}{r}\text { District Heating } \\
\text { Intensity } \\
\text { [kWh/m2] }\end{array}$ & $\begin{array}{r}\text { Water } \\
\text { Intensity } \\
{[\mathrm{m} 3 / \mathrm{m} 2]}\end{array}$ \\
\hline Lighting & 22.57 & 0.00 & 0.00 & 0.00 & 0.00 & 0.00 \\
\hline HVAC & 31.01 & 0.00 & 0.00 & 0.00 & 0.00 & 0.00 \\
\hline Other & 540.26 & 0.00 & 0.00 & 0.00 & 0.00 & 0.00 \\
\hline Total & 593.83 & 0.00 & 0.00 & 0.00 & 0.00 & 0.00 \\
\hline
\end{tabular}

Electric Loads Satisfied

\begin{tabular}{|l|r|r|}
\hline & Electricity [kWh] & Percent Electricity [\%] \\
\hline Fuel-Fired Power Generation & 0.000 & 0.00 \\
\hline High Temperature Geothermal* & 0.000 & 0.00 \\
\hline Photovoltaic Power & 0.000 & 0.00 \\
\hline Wind Power & 0.000 & 0.00 \\
\hline Power Conversion & 0.000 & 0.00 \\
\hline Net Decrease in On-Site Storage & 0.000 & 0.00 \\
\hline Total On-Site Electric Sources & 0.000 & 0.00 \\
\hline & & \\
\hline Electricity Coming From Utility & 87603.346 & 100.00 \\
\hline Surplus Electricity Going To Utility & 0.000 & 0.00 \\
\hline Net Electricity From Utility & 87603.346 & 100.00 \\
\hline & & 100.00 \\
\hline Total On-Site and Utility Electric Sources & 87603.346 & 100.00 \\
\hline Total Electricity End Uses & 87603.346 & \\
\hline
\end{tabular}

\section{Setpoint Not Met Criteria}

\section{Degrees [deltaC]}

Tolerance for Zone Heating Setpoint Not Met Time 1.11

Tolerance for Zone Cooling Setpoint Not Met Time 


\section{Comfort and Setpoint Not Met Summary}

\begin{tabular}{|l|r|}
\hline & Facility [Hours] \\
\hline Time Setpoint Not Met During Occupied Heating & 1808.83 \\
\hline Time Setpoint Not Met During Occupied Cooling & 8760.00 \\
\hline Time Not Comfortable Based on Simple ASHRAE 55-2004 & 6330.50 \\
\hline
\end{tabular}

Report: Input Verification and Results Summary

For: Entire Facility

\section{General}

\begin{tabular}{|l|r|r|}
\hline & Value \\
\hline Program Version and Build & EnergyPlus, Version 8.6.0-198c6a3cff, YMD=2019.04.09 23:10 \\
\hline RunPeriod & ER-09 (01-01:31-12) \\
\hline Weather File & Toronto Int'I ON CAN WYEC2-B-04714 WMO\#=716240 \\
\hline Latitude [deg] & 43.67 \\
\hline Longitude [deg] & -79.6 \\
\hline Elevation [m] & 173.00 \\
\hline Time Zone & -5.0 \\
\hline North Axis Angle [deg] & 0.00 \\
\hline Rotation for Appendix G [deg] & 0.00 \\
\hline Hours Simulated [hrs] & 8760.00
\end{tabular}

\section{Skylight-Roof Ratio}

\begin{tabular}{|l|r|}
\hline & Total \\
\hline Gross Roof Area [m2] & 0.00 \\
\hline Skylight Area [m2] & 0.00 \\
\hline Skylight-Roof Ratio [\%] & 0.00 \\
\hline
\end{tabular}


PERFORMANCE

Zone Summary

\begin{tabular}{|c|c|c|c|c|c|c|c|c|c|c|c|c|}
\hline & 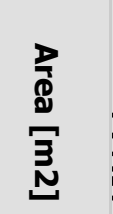 & 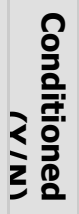 & 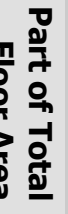 & 冚 $\frac{\delta}{\underline{\omega}}$ & $\begin{array}{l}3 \\
\frac{3}{\bar{E}} \\
\frac{\overline{0}}{\overline{0}} \\
\frac{\bar{D}}{1}\end{array}$ & 옳 웅 & 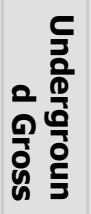 & 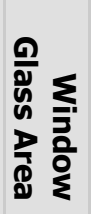 & 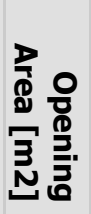 & 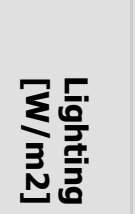 & 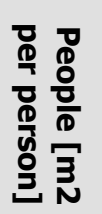 & 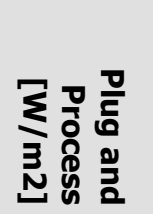 \\
\hline OBASEMENT:ZONE & 48.91 & Yes & Yes & 68.48 & 1.00 & 0.00 & 0.00 & 0.00 & 0.00 & 1.2500 & 40.00 & 0.0000 \\
\hline 1X1:DCPLENUM & 15.71 & No & No & 7.07 & 1.00 & 0.00 & 0.00 & 0.00 & 0.00 & & & \\
\hline 1X1:ZONEA & 19.38 & Yes & Yes & 41.86 & 1.00 & 0.00 & 0.00 & 0.00 & 0.00 & 10.0000 & 9.01 & 11.7700 \\
\hline 1X1:ZONEC & 7.02 & Yes & Yes & 15.66 & 1.00 & 0.00 & 0.00 & 0.00 & 0.00 & 10.0000 & 9.01 & 11.7700 \\
\hline 1X1:ZONEB & 7.58 & Yes & Yes & 15.66 & 1.00 & 0.00 & 0.00 & 0.00 & 0.00 & 10.0000 & 9.01 & 11.7700 \\
\hline 1X2DC:DC & 15.71 & Yes & Yes & 43.99 & 1.00 & 0.00 & 0.00 & 0.00 & 0.00 & 12.5000 & 10.39 & 553.0000 \\
\hline 1X3:ZONE2 & 28.70 & No & No & 20.09 & 1.00 & 0.00 & 0.00 & 0.00 & 0.00 & & & \\
\hline 2:ZONE1 & 48.91 & Yes & Yes & 68.48 & 1.00 & 0.00 & 0.00 & 0.00 & 0.00 & 10.0000 & 9.01 & 11.7700 \\
\hline Total & 147.52 & & & 254.14 & & 0.00 & 0.00 & 0.00 & 0.00 & 7.3650 & 12.36 & 65.5067 \\
\hline Conditioned Total & 147.52 & & & 254.14 & & 0.00 & 0.00 & 0.00 & 0.00 & 7.3650 & 12.36 & 65.5067 \\
\hline Unconditioned Total & 44.41 & & & 27.16 & & 0.00 & 0.00 & 0.00 & 0.00 & 0.0000 & & 0.0000 \\
\hline Not Part of Total & 44.41 & & & 27.16 & & 0.00 & 0.00 & 0.00 & 0.00 & 0.0000 & & 0.0000 \\
\hline
\end{tabular}

Report: Demand End Use Components Summary

For: Entire Facility

End Uses By Subcategory

\begin{tabular}{|c|c|c|c|c|c|c|c|}
\hline & 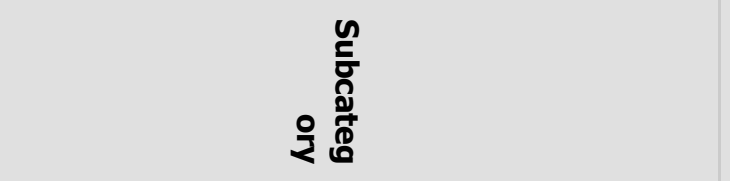 & 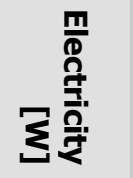 & 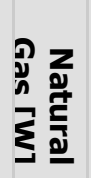 & 导导 & $\begin{array}{l}\text { 음 } \\
\text { 을 } \\
\text { 목 }\end{array}$ & 资导 & 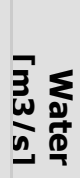 \\
\hline \multirow[t]{2}{*}{ Heating } & Boiler & 0.00 & 0.00 & 0.00 & 0.00 & 0.00 & 0.00 \\
\hline & Boiler Parasitic & 0.00 & 0.00 & 0.00 & 0.00 & 0.00 & 0.00 \\
\hline Cooling & General & 1588.94 & 40.00 & 0.00 & 0.00 & 0.00 & 0.00 \\
\hline \multirow[t]{6}{*}{ Interior Lighting } & EQUIPMENT\#0Basement:Zone\#GeneralLights & 61.14 & 40.00 & 0.00 & 0.00 & 0.00 & 0.00 \\
\hline & ELECTRIC EQUIPMENT\#1X1:ZoneA\#GeneralLights & 193.80 & 0.00 & 0.00 & 0.00 & 0.00 & 0.00 \\
\hline & ELECTRIC EQUIPMENT\#1X1:ZoneC\#GeneralLights & 70.25 & 0.00 & 0.00 & 0.00 & 0.00 & 0.00 \\
\hline & ELECTRIC EQUIPMENT\# 1 X1:ZoneB\#GeneralLights & 75.77 & 70.00 & 0.00 & 0.00 & 0.00 & 0.00 \\
\hline & ELECTRIC EQUIPMENT\#1X2DC:DC\#GeneralLights & 196.38 & 30.00 & 0.00 & 0.00 & 0.00 & 0.00 \\
\hline & ELECTRIC EQUIPMENT\#2:Zone1\#GeneralLights & 489.15 & 0.00 & 0.00 & 0.00 & 0.00 & 0.00 \\
\hline Exterior Lighting & General & 0.00 & 0.00 & 0.00 & 0.00 & 0.00 & 0.00 \\
\hline
\end{tabular}




\begin{tabular}{|c|c|c|c|c|c|c|c|}
\hline Interior Equipment & ELECTRIC EQUIPMENT\# 1X1:ZoneA\#05 & 228.11 & 0.00 & 0.00 & 0.00 & 0.00 & 0.00 \\
\hline & ELECTRIC EQUIPMENT\#1X1:ZoneC\#05 & 82.68 & 0.00 & 0.00 & 0.00 & 0.00 & 0.00 \\
\hline & ELECTRIC EQUIPMENT\# 1X1:ZoneB\#05 & 89.18 & 0.00 & 0.00 & 0.00 & 0.00 & 0.00 \\
\hline & ELECTRIC EQUIPMENT\#1X2DC:DC\#05 & 8688.02 & 0.00 & 0.00 & 0.00 & 0.00 & 0.00 \\
\hline & ELECTRIC EQUIPMENT\#2:Zone1\#05 & 575.73 & 0.00 & 0.00 & 0.00 & 0.00 & 0.00 \\
\hline Exterior Equipment & General & 0.00 & 0.00 & 0.00 & 0.00 & 0.00 & 0.00 \\
\hline Fans & General & 365.39 & 0.00 & 0.00 & 0.00 & 0.00 & 0.00 \\
\hline Pumps & General & 58.47 & 0.00 & 0.00 & 0.00 & 0.00 & 0.00 \\
\hline Heat Rejection & General & 0.00 & 0.00 & 0.00 & 0.00 & 0.00 & 0.00 \\
\hline Humidification & General & 0.00 & 0.00 & 0.00 & 0.00 & 0.00 & 0.00 \\
\hline Heat Recovery & General & 0.00 & 0.00 & 0.00 & 0.00 & 0.00 & 0.00 \\
\hline Water Systems & General & 0.00 & 0.00 & 0.00 & 0.00 & 0.00 & 0.00 \\
\hline Refrigeration & General & 0.00 & 0.00 & 0.00 & 0.00 & 0.00 & 0.00 \\
\hline Generators & General & 0.00 & 0.00 & 0.00 & 0.00 & 0.00 & 0.00 \\
\hline
\end{tabular}

Report: Climatic Data Summary

For: Entire Facility

SizingPeriod:DesignDay

\begin{tabular}{|c|c|c|c|c|c|c|}
\hline & $\begin{array}{r}\text { Maximum Dry } \\
\text { Bulb [C] }\end{array}$ & $\begin{array}{r}\text { Daily Temperature } \\
\text { Range [deltaC] }\end{array}$ & $\begin{array}{r}\text { Humidity } \\
\text { Value }\end{array}$ & $\begin{array}{r}\text { Humidity } \\
\text { Type }\end{array}$ & $\begin{array}{l}\text { Wind } \\
\text { Speed } \\
{[\mathrm{m} / \mathrm{s}]}\end{array}$ & $\begin{array}{r}\text { Wind } \\
\text { Direction }\end{array}$ \\
\hline $\begin{array}{l}\text { SUMMER DESIGN DAY } \\
\text { IN ER-09 (01-01:31- } \\
\text { 12) JUL }\end{array}$ & 31.40 & 9.90 & 22.40 & Wetbulb [C] & 0.00 & 0.00 \\
\hline $\begin{array}{l}\text { WINTER DESIGN DAY } \\
\text { IN ER-09 (01-01:31- } \\
\text { 12) }\end{array}$ & -18.10 & 0.00 & -18.10 & Wetbulb [C] & 14.20 & 0.00 \\
\hline
\end{tabular}


Interior Fenestration

\begin{tabular}{|c|c|c|c|c|c|c|c|}
\hline & $\begin{array}{l}\varrho \\
\frac{0}{3} \\
0 \\
\frac{0}{1} \\
\frac{1}{2} \\
\frac{7}{0}\end{array}$ & 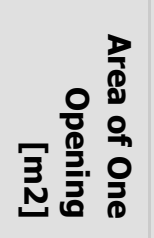 & 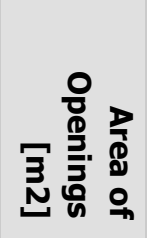 & 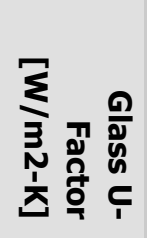 & 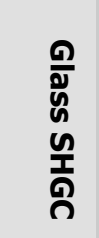 & 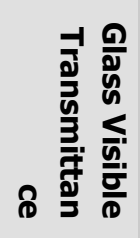 & 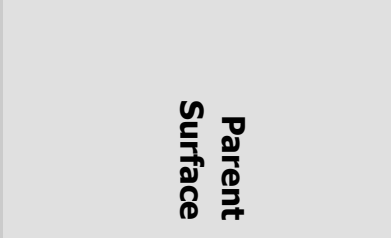 \\
\hline $\begin{array}{l}\text { 1X2DC:ZONEAA_PARTITI } \\
\text { ON_5_0_0_0_0_0_WIN }\end{array}$ & 1001 & 6.45 & 6.45 & 2.665 & 0.703 & 0.781 & $\begin{array}{r}\text { 1X2DC:ZONEAA_PARTITIO } \\
\text { N_5_0_0 }\end{array}$ \\
\hline $\begin{array}{l}\text { 1X2DC:ZONEAA_PARTITI } \\
\text { ON_6_0_0_1_0_1_WIN }\end{array}$ & 1001 & 7.46 & 7.46 & 2.665 & 0.703 & 0.781 & $\begin{array}{r}\text { 1X2DC:ZONEAA_PARTITIO } \\
\text { N_6_0_0 }\end{array}$ \\
\hline $\begin{array}{l}\text { 1X2DC:DC_PARTITION_2 } \\
\text { 0_0_0_0_0_WIN_10040 }\end{array}$ & 1001 & 6.45 & 6.45 & 2.665 & 0.703 & 0.781 & $\begin{array}{r}\text { 1X2DC:DC_PARTITION_2 } \\
0 \_10038\end{array}$ \\
\hline $\begin{array}{l}\text { 1X2DC:DC_PARTITION_5_ } \\
\text { 0_0_1_0_1_WIN_10043 }\end{array}$ & 1001 & 7.46 & 7.46 & 2.665 & 0.703 & 0.781 & $\begin{array}{r}\text { 1X2DC:DC_PARTITION_5 } \\
0 \_10040\end{array}$ \\
\hline Total or Average & & & 27.82 & 2.665 & 0.703 & 0.781 & \\
\hline
\end{tabular}




\begin{tabular}{|c|c|c|c|c|c|c|c|c|c|c|c|c|}
\hline & $\begin{array}{l}N \\
0 \\
0 \\
0\end{array}$ & 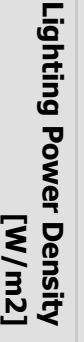 & 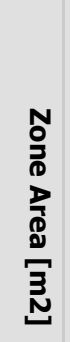 & 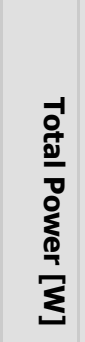 & 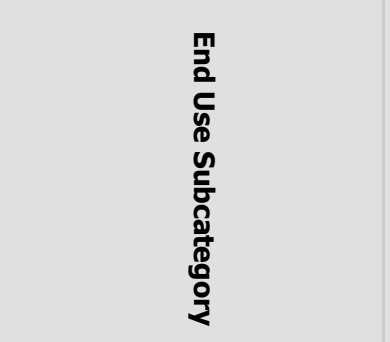 & $\begin{array}{l}\text { n } \\
\frac{0}{0} \\
\frac{0}{0} \\
\frac{\bar{c}}{0} \\
\text { z } \\
\stackrel{0}{0}\end{array}$ & $\begin{array}{l}: \\
\vdots \text { n } \\
\vdots \frac{0}{0} \\
\frac{0}{0} \\
\frac{0}{0} \\
\frac{0}{0}\end{array}$ & 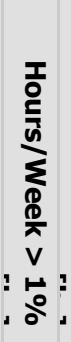 & 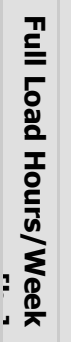 & 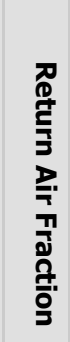 & 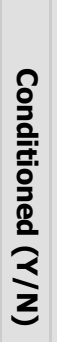 & 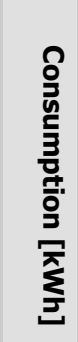 \\
\hline $\begin{array}{l}\text { OBASEMEN } \\
\text { T:ZONE } \\
\text { GENERAL } \\
\text { LIGHTING }\end{array}$ & $\begin{array}{r}\text { OBASEMEN } \\
\mathrm{T}: \mathrm{ZONE}\end{array}$ & $\begin{array}{r}1.25 \\
00\end{array}$ & $\begin{array}{r}48 . \\
91\end{array}$ & $\begin{array}{r}61.1 \\
4\end{array}$ & $\begin{array}{r}\text { ELECTRIC } \\
\text { EQUIPMENT\#OBasement:Z } \\
\text { one\#GeneralLights }\end{array}$ & $\begin{array}{r}\text { OFFICE_STORE_LI } \\
\text { GHT }\end{array}$ & $\begin{array}{rr} & 50 . \\
\Gamma & 05\end{array}$ & $\begin{array}{r}50 . \\
05\end{array}$ & $\begin{array}{r}50 . \\
05\end{array}$ & $\begin{array}{r}0.0 \\
000\end{array}$ & Y & $\begin{array}{r}159 . \\
58\end{array}$ \\
\hline $\begin{array}{l}\text { 1X1:ZONE } \\
\text { A } \\
\text { GENERAL } \\
\text { LIGHTING }\end{array}$ & $\begin{array}{r}1 X 1: Z O N E \\
A\end{array}$ & $\begin{array}{r}10.0 \\
000\end{array}$ & $\begin{array}{r}19 . \\
38\end{array}$ & $\begin{array}{r}193 . \\
80\end{array}$ & $\begin{array}{r}\text { ELECTRIC } \\
\text { EQUIPMENT\# 1X1:ZoneA\# } \\
\text { GeneralLights }\end{array}$ & $\begin{array}{r}\text { OFFICE_OPENOFF_- } \\
\text { LIGHT }\end{array}$ & $\begin{array}{r}60 . \\
\end{array}$ & $\begin{array}{r}60 . \\
07\end{array}$ & $\begin{array}{r}60 . \\
07\end{array}$ & $\begin{array}{r}0.0 \\
000\end{array}$ & $\mathrm{Y}$ & $\begin{array}{r}606 . \\
99\end{array}$ \\
\hline $\begin{array}{l}\text { 1X1:ZONE } \\
\text { C } \\
\text { GENERAL } \\
\text { LIGHTING }\end{array}$ & $\begin{array}{r}\text { 1X1:ZONE } \\
\mathrm{C}\end{array}$ & $\begin{array}{r}10.0 \\
000\end{array}$ & $\begin{array}{r}7.0 \\
2\end{array}$ & $\begin{array}{r}70.2 \\
5\end{array}$ & $\begin{array}{r}\text { ELECTRIC } \\
\text { EQUIPMENT\# 1X1:ZoneC\# } \\
\text { GeneralLights }\end{array}$ & $\begin{array}{r}\text { OFFICE_OPENOFF__ } \\
\text { LIGHT }\end{array}$ & $\begin{array}{r}60 . \\
07\end{array}$ & $\begin{array}{r}60 . \\
07\end{array}$ & $\begin{array}{r}60 . \\
07\end{array}$ & $\begin{array}{r}0.0 \\
000\end{array}$ & $\mathrm{Y}$ & $\begin{array}{r}220 . \\
02\end{array}$ \\
\hline $\begin{array}{l}\text { 1X1:ZONE } \\
\text { B } \\
\text { GENERAL } \\
\text { LIGHTING }\end{array}$ & $\begin{array}{r}\text { 1X1:ZONE } \\
\text { B }\end{array}$ & $\begin{array}{r}10.0 \\
000\end{array}$ & $\begin{array}{r}7.5 \\
8\end{array}$ & $\begin{array}{r}75.7 \\
7\end{array}$ & $\begin{array}{r}\text { ELECTRIC } \\
\text { EQUIPMENT\# 1X1:ZoneB\# } \\
\text { GeneralLights }\end{array}$ & $\begin{array}{r}\text { OFFICE_OPENOFF_ } \\
\text { LIGHT }\end{array}$ & $=\begin{array}{r}60 . \\
07\end{array}$ & $\begin{array}{r}60 . \\
07\end{array}$ & $\begin{array}{r}60 . \\
07\end{array}$ & $\begin{array}{r}0.0 \\
000\end{array}$ & $Y$ & $\begin{array}{r}237 . \\
32\end{array}$ \\
\hline $\begin{array}{l}\text { 1X2DC:DC } \\
\text { GENERAL } \\
\text { LIGHTING }\end{array}$ & $1 \mathrm{X} 2 \mathrm{DC}: \mathrm{DC}$ & $\begin{array}{r}12.5 \\
000\end{array}$ & $\begin{array}{r}15 . \\
71\end{array}$ & $\begin{array}{r}196 . \\
38\end{array}$ & $\begin{array}{r}\text { ELECTRIC } \\
\text { EQUIPMENT\#1X2DC:DC\# } \\
\text { GeneralLights }\end{array}$ & $\begin{array}{r}\text { MISC24HR_SERVER } \\
\text { ROOM_LIGHT }\end{array}$ & $\begin{array}{cc}2 & 56 . \\
\Gamma & 00\end{array}$ & $\begin{array}{r}56 . \\
00\end{array}$ & $\begin{array}{r}56 . \\
00\end{array}$ & $\begin{array}{r}0.0 \\
000\end{array}$ & $Y$ & $\begin{array}{r}573 . \\
44\end{array}$ \\
\hline $\begin{array}{l}\text { 2:ZONE1 } \\
\text { GENERAL } \\
\text { LIGHTING }\end{array}$ & 2:ZONE1 & $\begin{array}{r}10.0 \\
000\end{array}$ & $\begin{array}{r}48 . \\
91\end{array}$ & $\begin{array}{r}489 . \\
15\end{array}$ & $\begin{array}{r}\text { ELECTRIC } \\
\text { EQUIPMENT\#2:Zone1\#Ge } \\
\text { neralLights }\end{array}$ & $\begin{array}{r}\text { OFFICE_OPENOFF_- } \\
\text { LIGHT }\end{array}$ & $\begin{array}{r}60 . \\
\\
07\end{array}$ & $\begin{array}{r}60 . \\
07\end{array}$ & $\begin{array}{r}60 . \\
07\end{array}$ & $\begin{array}{r}0.0 \\
000\end{array}$ & Y & $\begin{array}{r}153 \\
2.01\end{array}$ \\
\hline $\begin{array}{l}\text { Interior } \\
\text { Lighting } \\
\text { Total }\end{array}$ & & $\begin{array}{r}7.36 \\
50\end{array}$ & $\begin{array}{r}147 \\
.52\end{array}$ & $\begin{array}{r}108 \\
6.50\end{array}$ & & & & & & & & $\begin{array}{r}332 \\
9.36\end{array}$ \\
\hline
\end{tabular}




\section{Daylighting}

\begin{tabular}{|l|r|r|r|r|r|}
\hline & Zone & $\begin{array}{r}\text { Daylighting } \\
\text { Type }\end{array}$ & $\begin{array}{r}\text { Control } \\
\text { Type }\end{array}$ & $\begin{array}{r}\text { Fraction Lighting Installed } \\
\text { Controlled }\end{array}$ & $\begin{array}{r}\text { Lighting } \\
\text { in Zone [W] }\end{array}$ \\
Controlled [W]
\end{tabular}

Report: Equipment Summary

For: Entire Facility

Central Plant

\begin{tabular}{|l|r|r|r|r|r|}
\hline & Type & $\begin{array}{r}\text { Nominal } \\
\text { Capacity [W] }\end{array}$ & $\begin{array}{r}\text { Nominal } \\
\text { Efficiency [W/W] }\end{array}$ & $\begin{array}{r}\text { IPLV in SI } \\
\text { Units [W/W] }\end{array}$ & $\begin{array}{r}\text { IPLV in IP Units } \\
\text { [Btu/W-h] }\end{array}$ \\
\hline HX & HeatExchanger:FluidToFluid & 10245.41 & & & \\
\hline BOILER & Boiler:HotWater & 12835.36 & 0.89 & & \\
\hline CHILLER & Chiller:Electric:EIR & 7068.56 & 5.50 & 5.96 & 20.35 \\
\hline
\end{tabular}




\section{Cooling Coils}

\begin{tabular}{|c|c|c|c|c|c|c|c|c|c|}
\hline & 方 & 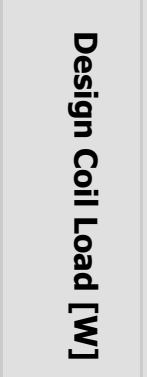 & 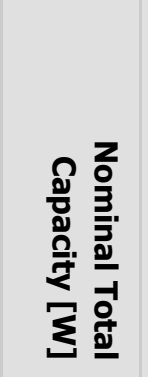 & 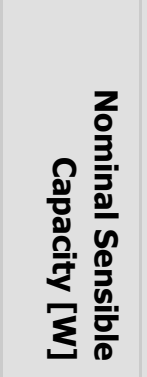 & 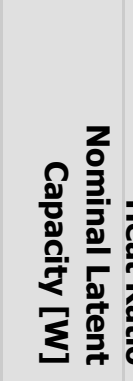 & 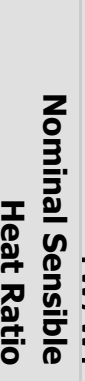 & 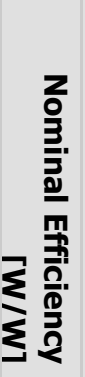 & 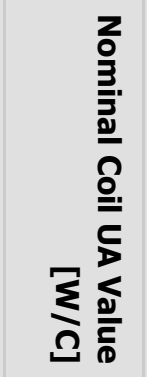 & 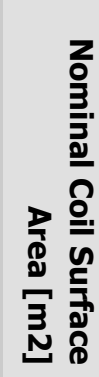 \\
\hline $\begin{array}{l}\text { OBASEMENT:ZONE FAN } \\
\text { COIL UNIT COOLING } \\
\text { COIL }\end{array}$ & Coil:Cooling:Water & 1601.29 & 1680.09 & 1175.72 & 504.37 & 0.70 & - & 122.39 & 1.24 \\
\hline $\begin{array}{l}1 X 1: Z O N E A \text { FAN COIL } \\
\text { UNIT COOLING COIL }\end{array}$ & Coil:Cooling:Water & 1358.81 & 1402.02 & 978.36 & 423.65 & 0.70 & & 102.18 & 1.04 \\
\hline $\begin{array}{l}1 X 1: Z O N E C \text { FAN COIL } \\
\text { UNIT COOLING COIL }\end{array}$ & Coil:Cooling:Water & 488.40 & 502.08 & 350.03 & 152.05 & 0.70 & & 36.64 & 0.37 \\
\hline $\begin{array}{l}1 X 1: Z O N E B \text { FAN COIL } \\
\text { UNIT COOLING COIL }\end{array}$ & Coil:Cooling:Water & 510.56 & 526.51 & 367.36 & 159.15 & 0.70 & & 38.38 & 0.39 \\
\hline $\begin{array}{l}\text { 1X2DC:DC FAN COIL } \\
\text { UNIT COOLING COIL }\end{array}$ & Coil:Cooling:Water & 10681.25 & 41391.08 & 32995.85 & 8395.23 & 0.80 & & 41748.66 & 423.44 \\
\hline $\begin{array}{l}\text { 2:ZONE1 FAN COIL UNIT } \\
\text { COOLING COIL }\end{array}$ & Coil:Cooling:Water & 3109.35 & 3296.57 & 2317.26 & 979.31 & 0.70 & & 238.20 & 2.42 \\
\hline
\end{tabular}

Fans

\begin{tabular}{|c|c|c|c|c|c|c|c|c|}
\hline & ఫ্ঠ & 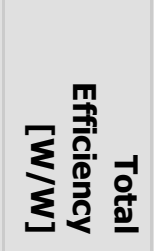 & 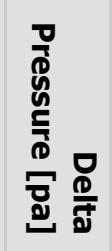 & 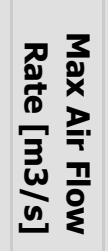 & 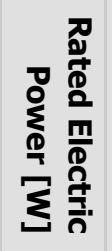 & 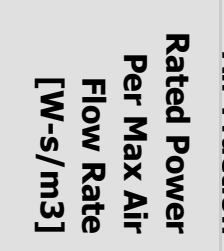 & 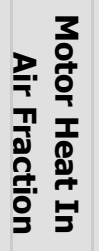 & 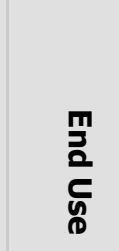 \\
\hline $\begin{array}{l}\text { OBASEMENT:ZONE FAN COIL UNIT } \\
\text { SUPPLY FAN }\end{array}$ & Fan:OnOff & 0.70 & 100.00 & 0.08 & 11.92 & 142.86 & 1.00 & General \\
\hline $\begin{array}{l}\text { 1X1:ZONEA FAN COIL UNIT } \\
\text { SUPPLY FAN }\end{array}$ & Fan:OnOff & 0.70 & 100.00 & 0.09 & 13.45 & 142.86 & 1.00 & General \\
\hline $\begin{array}{l}\text { 1X1:ZONEC FAN COIL UNIT } \\
\text { SUPPLY FAN }\end{array}$ & Fan:OnOff & 0.70 & 100.00 & 0.03 & 4.65 & 142.86 & 1.00 & General \\
\hline
\end{tabular}




\begin{tabular}{|l|l|l|l|l|l|l|l|l|}
\hline $\begin{array}{l}\text { 1X1:ZONEB FAN COIL UNIT } \\
\text { SUPPLY FAN }\end{array}$ & Fan:OnOff & 0.70 & 100.00 & 0.03 & 4.66 & 142.86 & 1.00 General \\
\hline $\begin{array}{l}\text { 1X2DC:DC FAN COIL UNIT SUPPLY } \\
\text { FAN }\end{array}$ & Fan:OnOff & 0.70 & 100.00 & 2.15 & 306.74 & 142.86 & 1.00 General \\
\hline $\begin{array}{l}\text { 2:ZONE1 FAN COIL UNIT SUPPLY } \\
\text { FAN }\end{array}$ & Fan:OnOff & 0.70100 .00 & 0.17 & 23.96 & 142.86 & 1.00 General \\
\hline
\end{tabular}

Pumps

\begin{tabular}{|c|c|c|c|c|c|c|c|}
\hline & Type & Control & $\begin{array}{r}\text { Head } \\
{[\mathrm{pa}]}\end{array}$ & $\begin{array}{r}\text { Water } \\
\text { Flow } \\
{[\mathrm{m} 3 / \mathrm{s}]}\end{array}$ & $\begin{array}{r}\text { Electric } \\
\text { Power } \\
\text { [W] }\end{array}$ & $\begin{array}{r}\text { Power Per } \\
\text { Water Flow } \\
\text { Rate [W- } \\
\text { s/m3] }\end{array}$ & $\begin{array}{r}\text { Motor } \\
\text { Efficiency } \\
{[W / W]}\end{array}$ \\
\hline $\begin{array}{l}\text { CHW LOOP } \\
\text { SUPPLY PUMP }\end{array}$ & Pump:VariableSpeed & Intermittent & 20000.00 & 0.000800 & 22.79 & 28490.03 & 0.90 \\
\hline $\begin{array}{l}\text { HW LOOP } \\
\text { SUPPLY PUMP }\end{array}$ & Pump:VariableSpeed & Intermittent & 20000.00 & 0.000306 & 8.71 & 28490.03 & 0.90 \\
\hline $\begin{array}{l}\text { CHW LOOP } 1 \\
\text { SUPPLY PUMP }\end{array}$ & Pump:VariableSpeed & Intermittent & 20000.00 & 0.000459 & 13.08 & 28490.03 & 0.90 \\
\hline $\begin{array}{l}\text { CONDENSER } \\
\text { LOOP SUPPLY } \\
\text { PUMP }\end{array}$ & Pump:VariableSpeed & Intermittent & 20000.00 & 0.000800 & 22.79 & 28490.03 & 0.90 \\
\hline
\end{tabular}

Report: System Summary

For: Entire Facility

Economizer

\begin{tabular}{|l|r|r|r|r|r|r|}
\hline $\begin{array}{r}\text { High Limit } \\
\text { Shutoff } \\
\text { Control }\end{array}$ & $\begin{array}{r}\text { Minimum } \\
\text { Outdoor Air } \\
{[\mathrm{m3} / \mathrm{s}]}\end{array}$ & $\begin{array}{r}\text { Maximum } \\
\text { Outdoor Air } \\
{[\mathrm{m3} / \mathrm{s}]}\end{array}$ & $\begin{array}{r}\text { Return } \\
\text { Air Temp } \\
\text { Limit }\end{array}$ & $\begin{array}{r}\text { Return Air } \\
\text { Enthalpy } \\
\text { Limit }\end{array}$ & $\begin{array}{r}\text { Outdoor Air } \\
\text { Temperature } \\
\text { Limit [C] }\end{array}$ & $\begin{array}{r}\text { Outdoor Air } \\
\text { Enthalpy } \\
\text { Limit [C] }\end{array}$ \\
\hline None & & & & & & \\
\hline
\end{tabular}


Time Setpoint Not Met

\begin{tabular}{|l|r|r|r|r|}
\hline & $\begin{array}{r}\text { During Heating } \\
\text { [hr] }\end{array}$ & $\begin{array}{r}\text { During Cooling } \\
\text { [hr] }\end{array}$ & $\begin{array}{r}\text { During Occupied } \\
\text { Heating [hr] }\end{array}$ & $\begin{array}{r}\text { During Occupied } \\
\text { Cooling [hr] }\end{array}$ \\
\hline OBASEMENT:ZONE & 1698.83 & 48.33 & 1457.00 & 36.83 \\
\hline 1 X1:ZONEA & 2702.00 & 41.00 & 1705.83 & 40.50 \\
\hline 1 1X1:ZONEC & 2899.17 & 30.33 & 1790.00 & 30.33 \\
\hline 1 1X1:ZONEB & 2901.33 & 30.33 & 1799.83 & 30.33 \\
\hline 1 1X2DC:DC & 0.00 & 8760.00 & 0.00 & 8760.00 \\
\hline 2:ZONE1 & 2787.67 & 41.83 & 1596.33 & 40.83 \\
\hline 1 1X1:DCPLENUM & 0.00 & 0.00 & 0.00 & 0.00 \\
\hline 1 1X3:ZONE2 & 0.00 & 0.00 & 0.00 & 0.00 \\
\hline Facility & 3052.00 & 8760.00 & 1808.83 & 8760.00 \\
\hline
\end{tabular}

Aggregated over the RunPeriods for Weather

Report: Energy Meters

For: Entire Facility

Timestamp: 2019-04-09 23:11:16

Annual and Peak Values - Electricity

\begin{tabular}{|c|c|c|c|c|c|}
\hline & 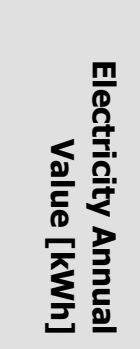 & 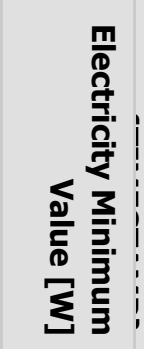 & 吾 & 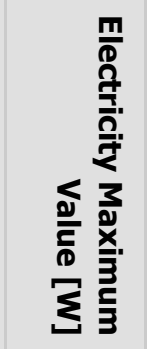 & 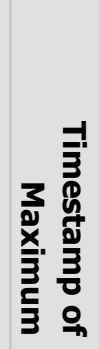 \\
\hline Electricity:Facility & 87603.42 & 9151.62 & $\begin{array}{r}01- \\
\text { JAN- } \\
00: 10\end{array}$ & 12763.02 & $\begin{array}{r}10- \\
\text { JUN- } \\
13: 10\end{array}$ \\
\hline Electricity:Building & 83029.47 & 8740.65 & $\begin{array}{r}01- \\
\text { JAN- } \\
00: 10\end{array}$ & 10750.21 & $\begin{array}{r}01- \\
\text { JAN- } \\
09: 10\end{array}$ \\
\hline
\end{tabular}




\begin{tabular}{|c|c|c|c|c|c|}
\hline Electricity:Zone:OBASEMENT:ZONE & 159.58 & 0.00 & $\begin{array}{r}01- \\
\text { JAN- } \\
00: 10\end{array}$ & 61.14 & $\begin{array}{r}01- \\
\text { JAN- } \\
08: 10\end{array}$ \\
\hline InteriorLights:Electricity & 3329.36 & 0.00 & $\begin{array}{r}01- \\
\text { JAN- } \\
00: 10\end{array}$ & 1086.50 & $\begin{array}{r}01- \\
\text { JAN- } \\
09: 10\end{array}$ \\
\hline InteriorLights:Electricity:Zone:OBASEMENT:ZONE & 159.58 & 0.00 & $\begin{array}{r}01- \\
\text { JAN- } \\
00: 10\end{array}$ & 61.14 & $\begin{array}{r}01- \\
\text { JAN- } \\
08: 10\end{array}$ \\
\hline $\begin{array}{l}\text { ELECTRIC } \\
\text { EQUIPMENT\#OBasement:Zone\#GeneralLights:InteriorLights:Electricit } \\
\text { y }\end{array}$ & 159.58 & 0.00 & $\begin{array}{r}01- \\
\text { JAN- } \\
00: 10\end{array}$ & 61.14 & $\begin{array}{r}01- \\
\text { JAN- } \\
08: 10\end{array}$ \\
\hline Electricity:Zone:1X1:ZONEA & 1446.99 & 12.30 & $\begin{array}{r}01- \\
\text { JAN- } \\
00: 10\end{array}$ & 421.91 & $\begin{array}{r}01- \\
\text { JAN- } \\
07: 10\end{array}$ \\
\hline InteriorLights:Electricity:Zone:1X1:ZONEA & 606.99 & 0.00 & $\begin{array}{r}01- \\
\text { JAN- } \\
00: 10\end{array}$ & 193.80 & $\begin{array}{l}01- \\
\text { JAN- } \\
07: 10\end{array}$ \\
\hline $\begin{array}{l}\text { ELECTRIC } \\
\text { EQUIPMENT\#1X1:ZoneA\#GeneralLights:InteriorLights:Electricity }\end{array}$ & 606.99 & 0.00 & $\begin{array}{r}01- \\
\text { JAN- } \\
00: 10\end{array}$ & 193.80 & $\begin{array}{r}01- \\
\text { JAN- } \\
07: 10\end{array}$ \\
\hline Electricity:Zone:1X1:ZONEC & 524.49 & 4.46 & $\begin{array}{r}01- \\
\text { JAN- } \\
00: 10\end{array}$ & 152.93 & $\begin{array}{r}01- \\
\text { JAN- } \\
07: 10\end{array}$ \\
\hline InteriorLights:Electricity:Zone:1X1:ZONEC & 220.02 & 0.00 & $\begin{array}{r}01- \\
\text { JAN- } \\
00: 10\end{array}$ & 70.25 & $\begin{array}{r}01- \\
\text { JAN- } \\
07: 10\end{array}$ \\
\hline $\begin{array}{l}\text { ELECTRIC } \\
\text { EQUIPMENT\#1X1:ZoneC\#GeneralLights:InteriorLights:Electricity }\end{array}$ & 220.02 & 0.00 & $\begin{array}{r}01- \\
\text { JAN- } \\
00: 10\end{array}$ & 70.25 & $\begin{array}{r}01- \\
\text { JAN- } \\
07: 10\end{array}$ \\
\hline Electricity:Zone:1X1:ZONEB & 565.74 & 4.81 & $\begin{array}{r}01- \\
\text { JAN- } \\
00: 10\end{array}$ & 164.96 & $\begin{array}{r}01- \\
\text { JAN- } \\
07: 10\end{array}$ \\
\hline InteriorLights:Electricity:Zone:1X1:ZONEB & 237.32 & 0.00 & $\begin{array}{r}01- \\
\text { JAN- } \\
00: 10\end{array}$ & 75.77 & $\begin{array}{r}01- \\
\text { JAN- } \\
07: 10\end{array}$ \\
\hline $\begin{array}{l}\text { ELECTRIC } \\
\text { EQUIPMENT\#1X1:ZoneB\#GeneralLights:InteriorLights:Electricity }\end{array}$ & 237.32 & 0.00 & $\begin{array}{r}01- \\
\text { JAN- } \\
00: 10\end{array}$ & 75.77 & $\begin{array}{r}01- \\
\text { JAN- } \\
07: 10\end{array}$ \\
\hline
\end{tabular}




\begin{tabular}{|c|c|c|c|c|c|}
\hline Electricity:Zone:1X2DC:DC & 76680.53 & 8688.02 & $\begin{array}{r}01- \\
\text { JAN- } \\
00: 10\end{array}$ & 8884.40 & $\begin{array}{r}01- \\
\text { JAN- } \\
09: 10\end{array}$ \\
\hline InteriorLights:Electricity:Zone:1X2DC:DC & 573.44 & 0.00 & $\begin{array}{r}01- \\
\text { JAN- } \\
00: 10\end{array}$ & 196.38 & $\begin{array}{r}01- \\
\text { JAN- } \\
09: 10\end{array}$ \\
\hline $\begin{array}{l}\text { ELECTRIC } \\
\text { EQUIPMENT\#1X2DC:DC\#GeneralLights:InteriorLights:Electricity }\end{array}$ & 573.44 & 0.00 & $\begin{array}{r}01- \\
\text { JAN- } \\
00: 10\end{array}$ & 196.38 & $\begin{array}{r}01- \\
\text { JAN- } \\
09: 10\end{array}$ \\
\hline Electricity:Zone:2:ZONE1 & 3652.12 & 31.05 & $\begin{array}{r}01- \\
\text { JAN- } \\
00: 10\end{array}$ & 1064.87 & $\begin{array}{r}01- \\
\text { JAN- } \\
07: 10\end{array}$ \\
\hline InteriorLights:Electricity:Zone:2:ZONE1 & 1532.01 & 0.00 & $\begin{array}{r}01- \\
\text { JAN- } \\
00: 10\end{array}$ & 489.15 & $\begin{array}{r}01- \\
\text { JAN- } \\
07: 10\end{array}$ \\
\hline $\begin{array}{l}\text { ELECTRIC } \\
\text { EQUIPMENT\#2:Zone1\#GeneralLights:InteriorLights:Electricity }\end{array}$ & 1532.01 & 0.00 & $\begin{array}{r}01- \\
\text { JAN- } \\
00: 10\end{array}$ & 489.15 & $\begin{array}{r}01- \\
\text { JAN- } \\
07: 10\end{array}$ \\
\hline InteriorEquipment:Electricity & 79700.10 & 8740.65 & $\begin{array}{r}01- \\
\text { JAN- } \\
00: 10\end{array}$ & 9663.72 & $\begin{array}{r}01- \\
\text { JAN- } \\
07: 10\end{array}$ \\
\hline InteriorEquipment:Electricity:Zone:1X1:ZONEA & 840.00 & 12.30 & $\begin{array}{r}01- \\
\text { JAN- } \\
00: 10\end{array}$ & 228.11 & $\begin{array}{r}01- \\
\text { JAN- } \\
07: 10\end{array}$ \\
\hline ELECTRIC EQUIPMENT\#1X1:ZoneA\#05:InteriorEquipment:Electricity & 840.00 & 12.30 & $\begin{array}{r}01- \\
\text { JAN- } \\
00: 10\end{array}$ & 228.11 & $\begin{array}{r}01- \\
\text { JAN- } \\
07: 10\end{array}$ \\
\hline InteriorEquipment:Electricity:Zone:1X1:ZONEC & 304.48 & 4.46 & $\begin{array}{r}01- \\
\text { JAN- } \\
00: 10\end{array}$ & 82.68 & $\begin{array}{r}01- \\
\text { JAN- } \\
07: 10\end{array}$ \\
\hline ELECTRIC EQUIPMENT\#1X1:ZoneC\#05:InteriorEquipment:Electricity & 304.48 & 4.46 & $\begin{array}{r}01- \\
\text { JAN- } \\
00: 10\end{array}$ & 82.68 & $\begin{array}{r}01- \\
\text { JAN- } \\
07: 10\end{array}$ \\
\hline InteriorEquipment:Electricity:Zone:1X1:ZONEB & 328.42 & 4.81 & $\begin{array}{r}01- \\
\text { JAN- } \\
00: 10\end{array}$ & 89.18 & $\begin{array}{r}01- \\
\text { JAN- } \\
07: 10\end{array}$ \\
\hline ELECTRIC EQUIPMENT\# 1X1:ZoneB\#05:InteriorEquipment:Electricity & 328.42 & 4.81 & $\begin{array}{r}01- \\
\text { JAN- } \\
00: 10\end{array}$ & 89.18 & $\begin{array}{r}01- \\
\text { JAN- } \\
07: 10\end{array}$ \\
\hline
\end{tabular}




\begin{tabular}{|c|c|c|c|c|c|}
\hline InteriorEquipment:Electricity:Zone:1X2DC:DC & 76107.09 & 8688.02 & $\begin{array}{r}01- \\
\text { JAN- } \\
00: 10\end{array}$ & 8688.02 & $\begin{array}{r}01- \\
\text { JAN- } \\
00: 10\end{array}$ \\
\hline ELECTRIC EQUIPMENT\# 1X2DC:DC\#05:InteriorEquipment:Electricity & 76107.09 & 8688.02 & $\begin{array}{r}01- \\
\text { JAN- } \\
00: 10\end{array}$ & 8688.02 & $\begin{array}{r}01- \\
\text { JAN- } \\
00: 10\end{array}$ \\
\hline InteriorEquipment:Electricity:Zone:2:ZONE1 & 2120.11 & 31.05 & $\begin{array}{r}01- \\
\text { JAN- } \\
00: 10\end{array}$ & 575.73 & $\begin{array}{r}01- \\
\text { JAN- } \\
07: 10\end{array}$ \\
\hline ELECTRIC EQUIPMENT\#2:Zone1\#05:InteriorEquipment:Electricity & 2120.11 & 31.05 & $\begin{array}{r}01- \\
\text { JAN- } \\
00: 10\end{array}$ & 575.73 & $\begin{array}{r}01- \\
\text { JAN- } \\
07: 10\end{array}$ \\
\hline Electricity:Zone: & 0.00 & 0.00 & $\begin{array}{r}01- \\
\text { JAN- } \\
00: 10\end{array}$ & 0.00 & $\begin{array}{r}01- \\
\text { JAN- } \\
00: 10\end{array}$ \\
\hline ElectricityPurchased:Facility & 87603.42 & 9151.62 & $\begin{array}{r}01- \\
\text { JAN- } \\
01: 50\end{array}$ & 12763.02 & $\begin{array}{r}10- \\
\text { JUN- } \\
13: 10\end{array}$ \\
\hline ElectricityPurchased:Plant & 87603.42 & 9151.62 & $\begin{array}{r}01- \\
\text { JAN- } \\
01: 50\end{array}$ & 12763.02 & $\begin{array}{r}10- \\
\text { JUN- } \\
13: 10\end{array}$ \\
\hline Cogeneration:ElectricityPurchased & 87603.42 & 9151.62 & $\begin{array}{r}01- \\
\text { JAN- } \\
01: 50\end{array}$ & 12763.02 & $\begin{array}{r}10- \\
\text { JUN- } \\
13: 10\end{array}$ \\
\hline ElectricitySurplusSold:Facility & 0.00 & 0.00 & $\begin{array}{r}01- \\
\text { JAN- } \\
00: 10\end{array}$ & 0.00 & $\begin{array}{r}01- \\
\text { JAN- } \\
00: 10\end{array}$ \\
\hline ElectricitySurplusSold:Plant & 0.00 & 0.00 & $\begin{array}{r}01- \\
\text { JAN- } \\
00: 10\end{array}$ & 0.00 & $\begin{array}{r}01- \\
\text { JAN- } \\
00: 10\end{array}$ \\
\hline Cogeneration:ElectricitySurplusSold & 0.00 & 0.00 & $\begin{array}{r}01- \\
\text { JAN- } \\
00: 10\end{array}$ & 0.00 & $\begin{array}{r}01- \\
\text { JAN- } \\
00: 10\end{array}$ \\
\hline ElectricityNet:Facility & 87603.42 & 9151.62 & $\begin{array}{r}01- \\
\text { JAN- } \\
01: 50\end{array}$ & 12763.02 & $\begin{array}{r}10- \\
\text { JUN- } \\
13: 10\end{array}$ \\
\hline ElectricityNet:Plant & 87603.42 & 9151.62 & $\begin{array}{r}01- \\
\text { JAN- } \\
01: 50\end{array}$ & 12763.02 & $\begin{array}{r}10- \\
\text { JUN- } \\
13: 10\end{array}$ \\
\hline
\end{tabular}




\begin{tabular}{|c|c|c|c|c|c|}
\hline Cogeneration:ElectricityNet & 87603.42 & 9151.62 & $\begin{array}{r}01- \\
\text { JAN- } \\
01: 50\end{array}$ & 12763.02 & $\begin{array}{r}10- \\
\text { JUN- } \\
13: 10\end{array}$ \\
\hline Electricity:HVAC & 3200.84 & 365.39 & $\begin{array}{r}01- \\
\text { JAN- } \\
01: 50\end{array}$ & 365.39 & $\begin{array}{r}01- \\
\text { JAN- } \\
00: 10\end{array}$ \\
\hline Fans:Electricity & 3200.84 & 365.39 & $\begin{array}{r}01- \\
\text { JAN- } \\
01: 50\end{array}$ & 365.39 & $\begin{array}{r}01- \\
\text { JAN- } \\
00: 10\end{array}$ \\
\hline General:Fans:Electricity & 3200.84 & 365.39 & $\begin{array}{r}01- \\
\text { JAN- } \\
01: 50\end{array}$ & 365.39 & $\begin{array}{r}01- \\
\text { JAN- } \\
00: 10\end{array}$ \\
\hline Electricity:Plant & 1373.11 & 45.58 & $\begin{array}{r}01- \\
\text { JAN- } \\
00: 20\end{array}$ & 1647.42 & $\begin{array}{r}10- \\
\text { JUN- } \\
13: 10\end{array}$ \\
\hline Heating:Electricity & 0.00 & 0.00 & $\begin{array}{r}01- \\
\text { JAN- } \\
00: 10\end{array}$ & 0.00 & $\begin{array}{r}01- \\
\text { JAN- } \\
00: 10\end{array}$ \\
\hline Boiler Parasitic:Heating:Electricity & 0.00 & 0.00 & $\begin{array}{r}01- \\
\text { JAN- } \\
00: 10\end{array}$ & 0.00 & $\begin{array}{r}01- \\
\text { JAN- } \\
00: 10\end{array}$ \\
\hline Cooling:Electricity & 969.36 & 0.00 & $\begin{array}{r}01- \\
\text { JAN- } \\
00: 10\end{array}$ & 1588.94 & $\begin{array}{r}10- \\
\text { JUN- } \\
13: 10\end{array}$ \\
\hline Pumps:Electricity & 403.75 & 45.58 & $\begin{array}{r}01- \\
\text { JAN- } \\
00: 20\end{array}$ & 58.67 & $\begin{array}{r}08- \\
\text { JUL- } \\
06: 10\end{array}$ \\
\hline
\end{tabular}

\section{Annual and Peak Values - Cooling}

\begin{tabular}{|c|c|c|c|c|c|}
\hline & $\begin{array}{r}\text { Cooling } \\
\text { Annual } \\
\text { Value } \\
\text { [kWh] }\end{array}$ & $\begin{array}{r}\text { Cooling } \\
\text { Minimum } \\
\text { Value [W] }\end{array}$ & $\begin{array}{r}\text { Timestamp of } \\
\text { Minimum } \\
\text { \{TIMESTAMP\} }\end{array}$ & $\begin{array}{r}\text { Cooling } \\
\text { Maximum } \\
\text { Value [W] }\end{array}$ & $\begin{array}{r}\text { Timestamp of } \\
\text { Maximum } \\
\text { \{TIMESTAMP\} }\end{array}$ \\
\hline PlantLoopCoolingDemand:Facility & 65190.70 & 5079.21 & 10-JUL-00:20 & 15996.24 & 09-JUL-08:30 \\
\hline PlantLoopCoolingDemand:HVAC & 65190.70 & 5079.21 & 10-JUL-00:20 & 15996.24 & 09-JUL-08:30 \\
\hline CoolingCoils:PlantLoopCoolingDemand & 65190.70 & 5079.21 & $10-J U L-00: 20$ & 15996.24 & 09-JUL-08:30 \\
\hline
\end{tabular}


Report: Sensible Heat Gain Summary

For: Entire Facility

Annual Building Sensible Heat Gain Components

\begin{tabular}{|c|c|c|c|c|c|c|c|c|c|c|c|c|c|c|c|c|c|c|}
\hline & 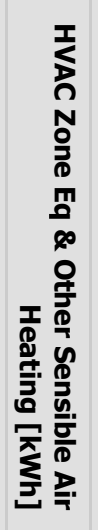 & 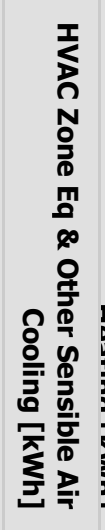 & 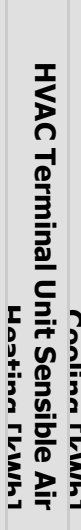 & 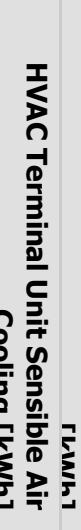 & 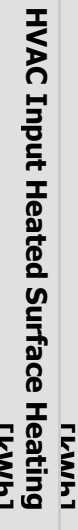 & 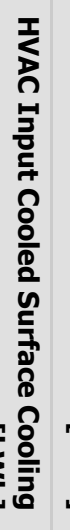 & 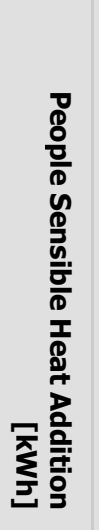 & 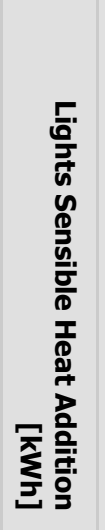 & 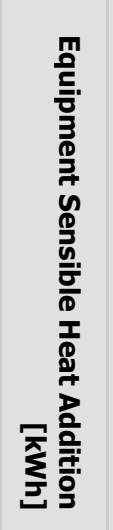 & 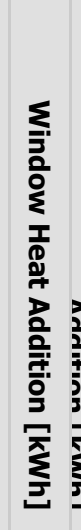 & 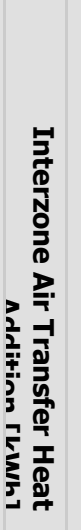 & 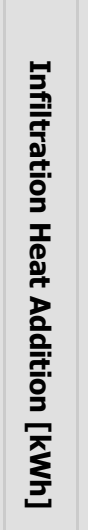 & 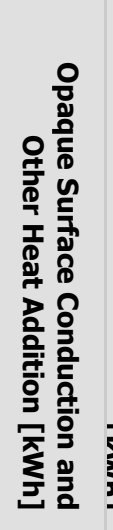 & 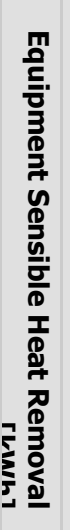 & 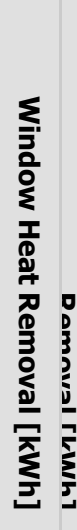 & 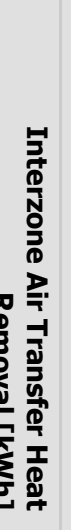 & 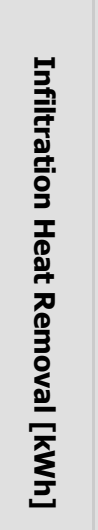 & 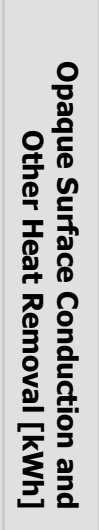 \\
\hline & $\begin{array}{r}99.48 \\
3\end{array}$ & 487.00 & $\begin{array}{r}0.0 \\
00\end{array}$ & $\begin{array}{r}0.0 \\
00\end{array}$ & $\begin{array}{r}0.0 \\
00\end{array}$ & $\begin{array}{c}0.03 \\
00\end{array}$ & $\begin{array}{r}306.35 \\
1\end{array}$ & $\begin{array}{r}159.58 \\
4\end{array}$ & 0.000 & $\begin{array}{r}0.0 \\
00\end{array}$ & $\begin{array}{r}0.0 \\
00\end{array}$ & $\begin{array}{r}23.7 \\
63\end{array}$ & $\begin{array}{r}2382.3 \\
51\end{array}$ & $\begin{array}{r}0.0 \\
00\end{array}$ & $\begin{array}{r}0.0 \\
00\end{array}$ & $\begin{array}{r}0.0 \\
00\end{array}$ & $\begin{array}{r}2484.5 \\
3\end{array}$ & 0.000 \\
\hline 1X1:Z & $\begin{array}{r}119.9 \\
58\end{array}$ & $612.44^{-}$ & $\begin{array}{r}0.0 \\
00\end{array}$ & $\begin{array}{r}0.0 \\
00\end{array}$ & $\begin{array}{r}0.0 \\
00\end{array}$ & $\begin{array}{c}0.04 \\
00\end{array}$ & $\begin{array}{r}430.38 \\
6\end{array}$ & $\begin{array}{r}606.99 \\
1\end{array}$ & $\begin{array}{r}840.00 \\
1\end{array}$ & $\begin{array}{r}0.0 \\
00\end{array}$ & $\begin{array}{r}0.0 \\
00\end{array}$ & $\begin{array}{r}3.19 \\
6\end{array}$ & $\begin{array}{r}4258.0 \\
77\end{array}$ & $\begin{array}{r}0.0 \\
00\end{array}$ & $\begin{array}{r}0.0 \\
00\end{array}$ & $\begin{array}{r}0.0 \\
00\end{array}$ & 5646 & 0.000 \\
\hline 1X1:ZONEC & $\begin{array}{r}41.90 \\
2\end{array}$ & 163.83 & $\begin{array}{r}0.0 \\
00\end{array}$ & $\begin{array}{r}0.0 \\
00\end{array}$ & $\begin{array}{r}0.0 \\
00\end{array}$ & $\begin{array}{c}0.01 \\
00\end{array}$ & $\begin{array}{r}158.21 \\
0\end{array}$ & $\begin{array}{r}220.01 \\
7\end{array}$ & $\begin{array}{r}304.47 \\
6\end{array}$ & $\begin{array}{r}0.0 \\
00\end{array}$ & $\begin{array}{r}0.0 \\
00\end{array}$ & $\begin{array}{r}1.36 \\
6\end{array}$ & $\begin{array}{r}1260.1 \\
12\end{array}$ & $\begin{array}{r}0.0 \\
00\end{array}$ & $\begin{array}{r}0.0 \\
00\end{array}$ & $\begin{array}{r}0.0 \\
00\end{array}$ & $\begin{array}{r}1822.2^{-} \\
6\end{array}$ & 0.000 \\
\hline 1X1:ZONEB & $\begin{array}{r}41.72 \\
6\end{array}$ & $160.46^{-}$ & $\begin{array}{r}0.0 \\
00\end{array}$ & $\begin{array}{r}0.0 \\
00\end{array}$ & $\begin{array}{r}0.0 \\
00\end{array}$ & $\begin{array}{c}0.01 \\
00\end{array}$ & $\begin{array}{r}171.43 \\
9\end{array}$ & $\begin{array}{r}237.32 \\
1\end{array}$ & $\begin{array}{r}328.42 \\
3\end{array}$ & $\begin{array}{r}0.0 \\
00\end{array}$ & $\begin{array}{r}0.0 \\
00\end{array}$ & $\begin{array}{r}1.49 \\
5\end{array}$ & $\begin{array}{r}1178.4 \\
65\end{array}$ & $\begin{array}{r}0.0 \\
00\end{array}$ & $\begin{array}{r}0.0 \\
00\end{array}$ & $\begin{array}{r}0.0 \\
00\end{array}$ & $\begin{array}{r}1798.4 \\
1\end{array}$ & 0.000 \\
\hline 1X2DC:DC & 0.000 & $\begin{array}{r}59218 . \\
25\end{array}$ & $\begin{array}{r}0.0 \\
00\end{array}$ & $\begin{array}{r}0.0 \\
00\end{array}$ & $\begin{array}{r}0.0 \\
00\end{array}$ & $\begin{array}{c}0.03 \\
00\end{array}$ & $\begin{array}{r}381.53 \\
4\end{array}$ & $\begin{array}{r}573.44 \\
1\end{array}$ & $\begin{array}{r}76107 . \\
091\end{array}$ & $\begin{array}{r}0.0 \\
00\end{array}$ & $\begin{array}{r}0.0 \\
00\end{array}$ & $\begin{array}{r}0.00 \\
0\end{array}$ & 0.000 & $\begin{array}{r}0.0 \\
00\end{array}$ & $\begin{array}{r}0.0 \\
00\end{array}$ & $\begin{array}{r}0.0 \\
00\end{array}$ & $\begin{array}{r}2571.7 \\
5\end{array}$ & $\begin{array}{r}15272 . \\
06\end{array}$ \\
\hline 2:ZONE1 & $\begin{array}{r}228.9 \\
72\end{array}$ & $\begin{array}{r}1372.8 \\
8\end{array}$ & $\begin{array}{r}0.0 \\
00\end{array}$ & $\begin{array}{r}0.0 \\
00\end{array}$ & $\begin{array}{r}0.0 \\
00\end{array}$ & $\begin{array}{c}0.01 \\
00\end{array}$ & $\begin{array}{r}1062.6 \\
35\end{array}$ & $\begin{array}{r}1532.0 \\
10\end{array}$ & $\begin{array}{r}2120.1 \\
10\end{array}$ & $\begin{array}{r}0.0 \\
00\end{array}$ & $\begin{array}{r}0.0 \\
00\end{array}$ & $\begin{array}{r}10.3 \\
07\end{array}$ & $\begin{array}{r}5819.5 \\
95\end{array}$ & $\begin{array}{r}0.0 \\
00\end{array}$ & $\begin{array}{r}0.0 \\
00\end{array}$ & $\begin{array}{r}0.0 \\
00\end{array}$ & $\begin{array}{r}9400.7 \\
4\end{array}$ & 0.000 \\
\hline $\begin{array}{l}\text { 1X1:DCI } \\
\text { UM }\end{array}$ & 0.000 & 0.000 & $\begin{array}{r}0.0 \\
00\end{array}$ & $\begin{array}{r}0.0 \\
00\end{array}$ & $\begin{array}{r}0.0 \\
00\end{array}$ & $\begin{array}{r}0.0 \\
00\end{array}$ & 0.000 & 0.000 & 0.000 & $\begin{array}{r}0.0 \\
00\end{array}$ & $\begin{array}{r}0.0 \\
00\end{array}$ & $\begin{array}{r}0.00 \\
2\end{array}$ & $\begin{array}{r}118.10 \\
5\end{array}$ & $\begin{array}{r}0.0 \\
00\end{array}$ & $\begin{array}{r}0.0 \\
00\end{array}$ & $\begin{array}{r}0.0 \\
00\end{array}$ & $118.11^{-}$ & 0.000 \\
\hline 1X3:ZONE2 & 0.000 & 0.000 & $\begin{array}{r}0.0 \\
00\end{array}$ & $\begin{array}{r}0.0 \\
00\end{array}$ & $\begin{array}{r}0.0 \\
00\end{array}$ & $\begin{array}{r}0.0 \\
00\end{array}$ & 0.000 & 0.000 & 0.000 & $\begin{array}{r}0.0 \\
00\end{array}$ & $\begin{array}{r}0.0 \\
00\end{array}$ & $\begin{array}{r}0.57 \\
6\end{array}$ & $\begin{array}{r}242.45 \\
3\end{array}$ & $\begin{array}{r}0.0 \\
00\end{array}$ & $\begin{array}{r}0.0 \\
00\end{array}$ & $\begin{array}{r}0.0 \\
00\end{array}$ & 243.03 & 0.000 \\
\hline al $\mathrm{F}$ & $\begin{array}{r}32.0 \\
42\end{array}$ & $\begin{array}{r}62014 . \\
87\end{array}$ & $\begin{array}{r}0.0 \\
00\end{array}$ & $\begin{array}{r}0.0 \\
00\end{array}$ & $\begin{array}{r}0.0 \\
00\end{array}$ & $\begin{array}{c}0.02 \\
00\end{array}$ & $\begin{array}{r}2510.5 \\
55\end{array}$ & $\begin{array}{r}3329.3 \\
65\end{array}$ & $\begin{array}{r}79700 . \\
101\end{array}$ & $\begin{array}{r}0.0 \\
00\end{array}$ & $\begin{array}{r}0.0 \\
00\end{array}$ & $\begin{array}{r}40.7 \\
04\end{array}$ & $\begin{array}{r}15259 . \\
158\end{array}$ & $\begin{array}{r}0.0 \\
00\end{array}$ & $\begin{array}{r}0.0 \\
00\end{array}$ & $\begin{array}{r}0.0 \\
00\end{array}$ & $\begin{array}{r}24084 . \\
99\end{array}$ & $\begin{array}{r}15272 . \\
06\end{array}$ \\
\hline
\end{tabular}




\begin{tabular}{|c|c|c|c|c|c|c|c|c|c|c|c|c|c|c|c|c|c|c|c|}
\hline & 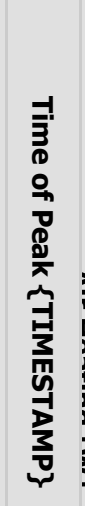 & 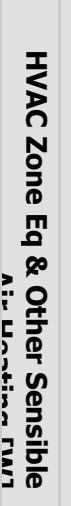 & 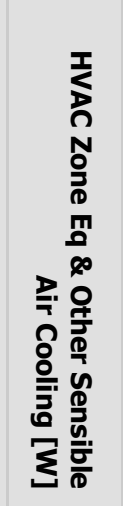 & 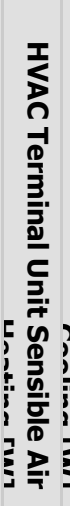 & 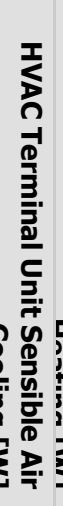 & 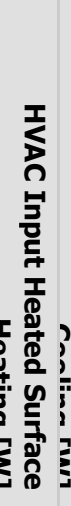 & 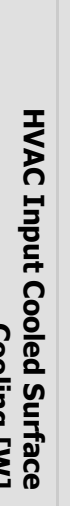 & 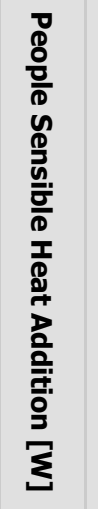 & 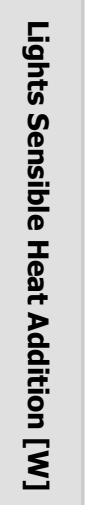 & 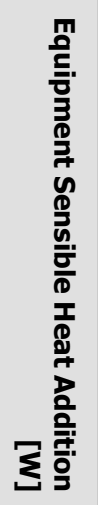 & 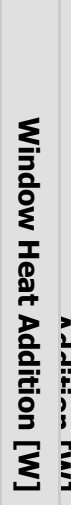 & 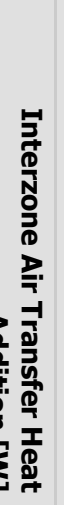 & 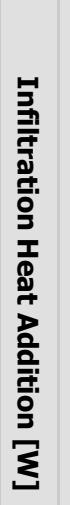 & 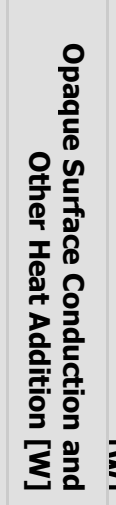 & 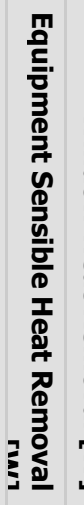 & 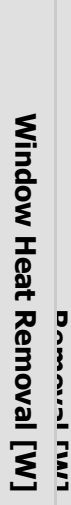 & 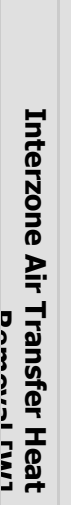 & 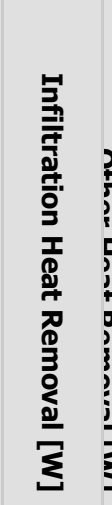 & 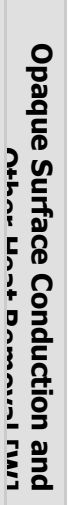 \\
\hline $\begin{array}{l}\text { OBASEMENT:ZO } \\
\text { NE }\end{array}$ & \begin{tabular}{|r|}
$15-$ \\
JUL- \\
$05: 0$ \\
1 \\
\end{tabular} & $\begin{array}{r}0.0 \\
0\end{array}$ & $1392.72^{-}$ & $\begin{array}{r}0.0 \\
0\end{array}$ & $\begin{array}{r}0.0 \\
0\end{array}$ & $\begin{array}{r}0.0 \\
0\end{array}$ & $\begin{array}{r}0.0 \\
0\end{array}$ & 0.00 & 0.00 & 0.00 & $\begin{array}{r}0.0 \\
0\end{array}$ & $\begin{array}{r}0.0 \\
0\end{array}$ & $\begin{array}{r}0.0 \\
0\end{array}$ & $\begin{array}{r}1488.3 \\
0\end{array}$ & $\begin{array}{r}0.0 \\
0\end{array}$ & $\begin{array}{r}0.0 \\
0\end{array}$ & $\begin{array}{r}0.0 \\
0\end{array}$ & -95.58 & $\begin{array}{r}0.0 \\
0\end{array}$ \\
\hline 1X1:ZONEA & \begin{tabular}{|r|} 
06- \\
AUG- \\
$04: 0$ \\
1 \\
\end{tabular} & $\begin{array}{r}0.0 \\
0\end{array}$ & $1284.72^{-}$ & $\begin{array}{r}0.0 \\
0\end{array}$ & $\begin{array}{r}0.0 \\
0\end{array}$ & $\begin{array}{r}0.0 \\
0\end{array}$ & $\begin{array}{r}0.0 \\
0\end{array}$ & 0.00 & 0.00 & 12.30 & $\begin{array}{r}0.0 \\
0\end{array}$ & $\begin{array}{r}0.0 \\
0\end{array}$ & $\begin{array}{r}0.0 \\
0\end{array}$ & $\begin{array}{r}1975.1 \\
4\end{array}$ & $\begin{array}{r}0.0 \\
0\end{array}$ & $\begin{array}{r}0.0 \\
0\end{array}$ & $\begin{array}{r}0.0 \\
0\end{array}$ & 702.73 & $\begin{array}{r}0.0 \\
0\end{array}$ \\
\hline 1X1:ZONEC & \begin{tabular}{|r}
$06-$ \\
AUG- \\
$15: 2$ \\
3
\end{tabular} & $\begin{array}{r}0.0 \\
0\end{array}$ & -425.09 & $\begin{array}{r}0.0 \\
0\end{array}$ & $\begin{array}{r}0.0 \\
0\end{array}$ & $\begin{array}{r}0.0 \\
0\end{array}$ & $\begin{array}{r}0.0 \\
0\end{array}$ & 50.27 & 70.25 & 82.68 & $\begin{array}{r}0.0 \\
0\end{array}$ & $\begin{array}{r}0.0 \\
0\end{array}$ & $\begin{array}{r}0.0 \\
0\end{array}$ & 223.72 & $\begin{array}{r}0.0 \\
0\end{array}$ & $\begin{array}{r}0.0 \\
0\end{array}$ & $\begin{array}{r}0.0 \\
0\end{array}$ & -1.84 & $\begin{array}{r}0.0 \\
0\end{array}$ \\
\hline 1X1:ZONEB & $\begin{array}{r}\text { 06- } \\
\text { AUG- } \\
15: 2 \\
3\end{array}$ & $\begin{array}{r}0.0 \\
0\end{array}$ & -434.74 & $\begin{array}{r}0.0 \\
0\end{array}$ & $\begin{array}{r}0.0 \\
0\end{array}$ & $\begin{array}{r}0.0 \\
0\end{array}$ & $\begin{array}{r}0.0 \\
0\end{array}$ & 53.77 & 75.77 & 89.18 & $\begin{array}{r}0.0 \\
0\end{array}$ & $\begin{array}{r}0.0 \\
0\end{array}$ & $\begin{array}{r}0.0 \\
0\end{array}$ & 218.02 & $\begin{array}{r}0.0 \\
0\end{array}$ & $\begin{array}{r}0.0 \\
0\end{array}$ & $\begin{array}{r}0.0 \\
0\end{array}$ & -2.01 & $\begin{array}{r}0.0 \\
0\end{array}$ \\
\hline 1X2DC:DC & $\begin{array}{r}10- \\
\text { JUL- } \\
07: 4 \\
2 \\
\end{array}$ & $\begin{array}{r}0.0 \\
0\end{array}$ & $\begin{array}{r}10375.9 \\
4\end{array}$ & $\begin{array}{r}0.0 \\
0\end{array}$ & $\begin{array}{r}0.0 \\
0\end{array}$ & $\begin{array}{r}0.0 \\
0\end{array}$ & $\begin{array}{r}0.0 \\
0\end{array}$ & 0.00 & 0.00 & $\begin{array}{r}8688.0 \\
2\end{array}$ & $\begin{array}{r}0.0 \\
0\end{array}$ & $\begin{array}{r}0.0 \\
0\end{array}$ & $\begin{array}{r}0.0 \\
0\end{array}$ & $\begin{array}{r}1740.9 \\
7\end{array}$ & $\begin{array}{r}0.0 \\
0\end{array}$ & $\begin{array}{r}0.0 \\
0\end{array}$ & $\begin{array}{r}0.0 \\
0\end{array}$ & -53.05 & $\begin{array}{r}0.0 \\
0\end{array}$ \\
\hline 2:ZONE1 & $\begin{array}{r}15- \\
\text { JUL- } \\
04: 0 \\
1\end{array}$ & $\begin{array}{r}0.0 \\
0\end{array}$ & $2911.55^{-}$ & $\begin{array}{r}0.0 \\
0\end{array}$ & $\begin{array}{r}0.0 \\
0\end{array}$ & $\begin{array}{r}0.0 \\
0\end{array}$ & $\begin{array}{r}0.0 \\
0\end{array}$ & 0.00 & 0.00 & 31.05 & $\begin{array}{r}0.0 \\
0\end{array}$ & $\begin{array}{r}0.0 \\
0\end{array}$ & $\begin{array}{r}0.0 \\
0\end{array}$ & $\begin{array}{r}4722.5 \\
7\end{array}$ & $\begin{array}{r}0.0 \\
0\end{array}$ & $\begin{array}{r}0.0 \\
0\end{array}$ & $\begin{array}{r}0.0 \\
0\end{array}$ & $\begin{array}{r}1842.0 \\
7\end{array}$ & $\begin{array}{r}0.0 \\
0\end{array}$ \\
\hline 1X1:DCPLENUM & & $\begin{array}{r}0.0 \\
0\end{array}$ & 0.00 & $\begin{array}{r}0.0 \\
0\end{array}$ & $\begin{array}{r}0.0 \\
0\end{array}$ & $\begin{array}{r}0.0 \\
0\end{array}$ & $\begin{array}{r}0.0 \\
0\end{array}$ & 0.00 & 0.00 & 0.00 & $\begin{array}{r}0.0 \\
0\end{array}$ & $\begin{array}{r}0.0 \\
0\end{array}$ & $\begin{array}{r}0.0 \\
0\end{array}$ & 0.00 & $\begin{array}{r}0.0 \\
0\end{array}$ & $\begin{array}{r}0.0 \\
0\end{array}$ & $\begin{array}{r}0.0 \\
0\end{array}$ & 0.00 & $\begin{array}{r}0.0 \\
0\end{array}$ \\
\hline 1X3:ZONE2 & & $\begin{array}{r}0.0 \\
0\end{array}$ & 0.00 & $\begin{array}{r}0.0 \\
0\end{array}$ & $\begin{array}{r}0.0 \\
0\end{array}$ & $\begin{array}{r}0.0 \\
0\end{array}$ & $\begin{array}{r}0.0 \\
0\end{array}$ & 0.00 & 0.00 & 0.00 & $\begin{array}{r}0.0 \\
0\end{array}$ & $\begin{array}{r}0.0 \\
0\end{array}$ & $\begin{array}{r}0.0 \\
0\end{array}$ & 0.00 & $\begin{array}{r}0.0 \\
0\end{array}$ & $\begin{array}{r}0.0 \\
0\end{array}$ & $\begin{array}{r}0.0 \\
0\end{array}$ & 0.00 & $\begin{array}{r}0.0 \\
0\end{array}$ \\
\hline Total Facility & $\begin{array}{r}10- \\
\text { JUL- } \\
07: 4 \\
2\end{array}$ & $\begin{array}{r}0.0 \\
0\end{array}$ & $\begin{array}{r}14536.0 \\
8\end{array}$ & $\begin{array}{r}0.0 \\
0\end{array}$ & $\begin{array}{r}0.0 \\
0\end{array}$ & $\begin{array}{r}0.0 \\
0\end{array}$ & $\begin{array}{r}0.0 \\
0\end{array}$ & $\begin{array}{r}406.7 \\
3\end{array}$ & $\begin{array}{r}890.1 \\
1\end{array}$ & $\begin{array}{r}9663.7 \\
2\end{array}$ & $\begin{array}{r}0.0 \\
0\end{array}$ & $\begin{array}{r}0.0 \\
0\end{array}$ & $\begin{array}{r}0.0 \\
0\end{array}$ & $\begin{array}{r}5316.8 \\
2\end{array}$ & $\begin{array}{r}0.0 \\
0\end{array}$ & $\begin{array}{r}0.0 \\
0\end{array}$ & $\begin{array}{r}0.0 \\
0\end{array}$ & $\begin{array}{r}1741.3 \\
0\end{array}$ & $\begin{array}{r}0.0 \\
0\end{array}$ \\
\hline
\end{tabular}

Report: Component Sizing Summary

For: Entire Facility

ZoneHVAC:FourPipeFanCoil 


\begin{tabular}{|l|r|r|r|}
\hline & $\begin{array}{r}\text { Design Size Maximum } \\
\text { Supply Air Flow Rate } \\
\text { [m3/s] }\end{array}$ & $\begin{array}{r}\text { Design Size Maximum } \\
\text { Hot Water Flow [m3/s] }\end{array}$ & $\begin{array}{r}\text { Design Size Maximum } \\
\text { Cold Water Flow [m3/s] }\end{array}$ \\
\hline \begin{tabular}{l|l|l|} 
OBASEMENT:ZONE FAN \\
COIL UNIT
\end{tabular} & 0.083448 & 0.000011 & 0.000104 \\
\hline $\begin{array}{l}\text { 1X1:ZONEA FAN COIL } \\
\text { UNIT }\end{array}$ & 0.094136 & 0.000077 & 0.000088 \\
\hline $\begin{array}{l}\text { 1X1:ZONEC FAN COIL } \\
\text { UNIT }\end{array}$ & 0.032527 & 0.000026 & 0.000032 \\
\hline $\begin{array}{l}\text { 1X1:ZONEB FAN COIL } \\
\text { UNIT }\end{array}$ & 0.032636 & 0.000027 & 0.000033 \\
\hline $\begin{array}{l}\text { 1X2DC:DC FAN COIL } \\
\text { UNIT }\end{array}$ & 2.15 & 0.000035 & 0.000694 \\
\hline 2:ZONE1 FAN COIL UNIT & 0.167711 & 0.000130 & 0.000202 \\
\hline
\end{tabular}

User-Specified values were used. Design Size values were used if no User-Specified values were provided.

Fan:OnOff

\begin{tabular}{|l|r|}
\hline & Design Size Maximum Flow Rate $[\mathbf{m 3} / \mathbf{s}]$ \\
\hline OBASEMENT:ZONE FAN COIL UNIT SUPPLY FAN & 0.083448 \\
\hline 1X1:ZONEA FAN COIL UNIT SUPPLY FAN & 0.094136 \\
\hline 1X1:ZONEC FAN COIL UNIT SUPPLY FAN & 0.032527 \\
\hline 1 X1:ZONEB FAN COIL UNIT SUPPLY FAN & 0.032636 \\
\hline 1X2DC:DC FAN COIL UNIT SUPPLY FAN & 2.15 \\
\hline 2:ZONE1 FAN COIL UNIT SUPPLY FAN & 0.167711 \\
\hline
\end{tabular}

User-Specified values were used. Design Size values were used if no User-Specified values were provided. 


\section{Coil:Cooling:Water}
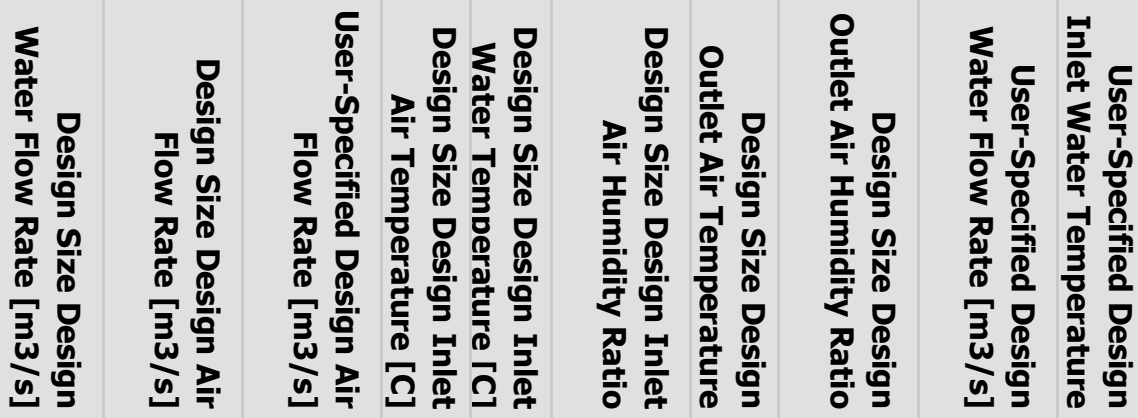

OBASEMENT:ZONE FAN COIL UNIT COOLING COIL

0.0001040 .0834480 .08344822 .996 .000 .01178314 .000 .009000

1X1:ZONEA FAN COIL UNIT COOLING COIL

0.0000880 .0941360 .06882523 .996 .000 .01156414 .000 .009000

1X1:ZONEC FAN COIL UNIT COOLING COIL

0.0000320 .0325270 .02453223 .996 .000 .01161914 .000 .009000

1X1:ZONEB FAN COIL UNIT COOLING COIL

0.0000330 .0326360 .02582923 .996 .000 .01157214 .000 .009000

1X2DC:DC FAN COIL UNIT COOLING COIL

0.000694

2.15

2.1518 .006 .000 .00905214 .000 .0090520 .00080013 .50

2:ZONE1 FAN COIL UNIT

COOLING COIL

0.0002020 .1677110 .16771123 .996 .000 .01116514 .000 .009000

User-Specified values were used. Design Size values were used if no User-Specified values were provided.

Pump:VariableSpeed

\begin{tabular}{|l|r|r|}
\hline & Design Flow Rate [m3/s] Design Power Consumption [W] \\
\hline CHW LOOP SUPPLY PUMP & 0.000800 & 22.79 \\
\hline HW LOOP SUPPLY PUMP & 0.000306 & 8.71 \\
\hline CHW LOOP 1 SUPPLY PUMP & 0.000459 & 13.08 \\
\hline CONDENSER LOOP SUPPLY PUMP & 0.000800 & 22.79 \\
\hline
\end{tabular}

User-Specified values were used. Design Size values were used if no User-Specified values were provided.

HeatExchanger:FluidToFluid 


\begin{tabular}{|r|r|r|r|}
\hline $\begin{array}{r}\text { Loop Supply Side } \\
\text { Design Fluid Flow } \\
\text { Rate [m3/s] }\end{array}$ & $\begin{array}{r}\text { Loop Demand Side } \\
\text { Design Fluid Flow } \\
\text { Rate [m3/s] }\end{array}$ & $\begin{array}{r}\text { Heat Exchanger U- } \\
\text { Factor Times Area } \\
\text { Value [W/C] }\end{array}$ & $\begin{array}{r}\text { Loop-to-loop Temperature } \\
\text { Difference Used to Size Heat } \\
\text { Exchanger U-Factor Times Area } \\
\text { Value [C] }\end{array}$ \\
\hline HX & 0.000800 & 648.07 & 19.00 \\
\hline
\end{tabular}

\section{CondenserLoop}

\begin{tabular}{|l|r|r|}
\hline & Maximum Loop Flow Rate [m3/s] & Condenser Loop Volume [m3] \\
\hline CONDENSER LOOP & 0.000800 & 0.600000 \\
\hline
\end{tabular}

User-Specified values were used. Design Size values were used if no User-Specified values were provided. 


\section{Bibliography}

ASHRAE. (2017). Energy Estimating and Modelling Method (Ch 19). In ASHRAE® Handbook Fundamentals (pp. 19.1-19.53). American Sociaty of Heating, Refrigeration and Air-Conditioning Engineers, Inc. Retrieved from https://app.knovel.com/hotlink/toc/id:kpASHRAEQ1/ashraehandbook-fundamentals/ashrae-handbook-fundamentals

Avgerinou, M., Bertoldi, P., \& Castellazzi, L. (2017). Trends in Data Centre Energy Consumption under the European Code of Conduct for Data Centre Energy Efficiency. Energies.

BEATY, D. L., \& QUIRK, D. (2015, November). Gaps in Modelling Data Center Energy. ASHRAE JOURNAL, pp. 76-82.

Beaty, D. L., \& Quirk, D. (2017, March). Changing Landscape of Data Centers (Part 1: Information Technology Equipment). ASHRAE Journal, 96-101.

Bertrand F. Tchanche, G. L. (2011). Low-grade heat conversion into power using organic Rankine cycles - A review of various applications. Renewable and Sustainable Energy Reviews, 3963-3979.

CIBSE. (2013). Ground Source Heat Pumps - CIBSE TM51: 2013 - 4.8 Absorption Cycle. CIBSE. Retrieved from https://app.knovel.com/hotlink/pdf/id:kt00U1IMNE/ground-source-heat-pumps/absorption-cycle

Cronin, D. (2011, September). Growth in data center electricity use 2005 to 2010: what do the numbers say? Mission Critical, 4(5), 21+. Retrieved from http://bi.galegroup.com.ezproxy.lib.ryerson.ca/global/article/GALE\%7CA270732798/ae7dc941a0b 4f15449d611ffa6c9be12?u=rpu_main

Datacom Equipment Power Trends and Cooling Applications (2nd Edition). (2012). American Society of Heating, Refrigerating and Air-Conditioning Engineers, Inc. Retrieved from https://app.knovel.com/hotlink/toc/id:kpDEPTCAE1/datacom-equipment-power/datacomequipment-power

Davies, G., Maidment, G., \& Tozer, R. (2016). Using data centres for combined heating and cooling: An investigation for London. Applied Thermal Engineering, 296-304.

DesignBuilder Software. (n.d.). Retrieved March 2019, from HYPERLINK "https://www.altensis.com/en/services/DesignBuilder-software/" https://www.altensis.com/en/services/DesignBuilder-software/

Deymi-Dashtebayaz, M., \& Valipour-Namanlo, S. (2019). Thermoeconomic and environmental feasibility of waste heat recovery of a data center using air source heat pump. Journal of Cleaner Production, 219, 117-126.

Our Facility - Earth Rangers. (2013). Retrieved from http://www.earthrangers.org/about/our-facility/

Ebrahimi, K., Jones, G. F., \& Fleischer, A. S. (2014). A review of data center cooling technology, operating conditions and the corresponding low-grade waste heat recovery opportunities. Renewable and Sustainable Energy Reviews, 622-638. 
Ebrahimi, K., Jones, G. F., \& Fleischer, A. S. (2015). Thermo-economic analysis of steady state waste heat recovery in data centers using absorption refrigeration. Applied Energy, 384-397.

EnergyPlusTM Documentation. (n.d.). Retrieved Jan 2019, from Getting Started - EnergyPlus Documentation: https://www.EnergyPlus.net/sites/default/files/docs/site_v8.3.0/GettingStarted/GettingStarted/inde x.html

Engineering Reference - Energyplus 8.0 - Big Ladder Software. (n.d.) Retrieved from https://bigladdersoftware.com/epx/docs/8-0/engineering-reference/page-023.html

Galli, F. (2018). Methodology for the exploitation of a data center waste heat: system for heating buildings. POLITECNICO DI TORINO: Thesis.

Gantz, J., \& Reinsel, D. (2013, February). The digital universe in 2020: big data, bigger digital shadows, and biggest growth in the far east - United States. IDC Country Brief.

Gao, J. (2014). Machine Learning Applications for Data Center Optimization. Google.

Ground-Source Heat Pumps (Earth-Energy Systems) | Natural Resources Canada. (2019). Retrieved from HYPERLINK "https://www.nrcan.gc.ca/energy/publications/efficiency/heating-heatpump/6833" https://www.nrcan.gc.ca/energy/publications/efficiency/heating-heat-pump/6833

Hallett, D., \& Paunon, C. (2014). Control Strategies for Data Centers - Trends Around the Globe. ASHRAE Winter Conference.

Jadhav, M., \& Chaudhari, P. (2015, Sep). Energy Performance Optimization of Server Room HVAC System. International Journal of Thermal Technologies, 5(3), 232-237.

Kant, K. (2009). Data center evolution A tutorial on state of the art, issues, and challenges. Computer Networks, 53, 2939-2965.

Kofinger, M., Basciotti, D., Schmidt, R., Meissner, E., Doczekal, C., \& Giovannini, A. (2016). Low temperature district heating in Austria: Energetic, ecologic and economic comparison of four case studies. Energy, 95-104.

Lucia, U., Simonetti, M., Chiesa, G., \& Grisolia, G. (2017). Ground-source pump system for heating and cooling: Review and thermodynamic approach. Renewable and Sustainable Energy Reviews, 867-874.

MURPHY, A. R., \& FUNG, A. S. (2015). TECHNICAL FEASILIBITY OF DATA CENTRE HEAT RECOVERY IN A COMMUNITY ENERGY NETWORK. Melbourne: AIRAH and IBPSA's Australasian Building Simulation 2017 Conference.

Oro, E., Depoorter, V., Pflugradt, N., \& Salom, J. (2015). Overview of direct air free cooling and thermal energy storage potential energy savings in data centres. Applied Thermal Engineering, 85, 100110.

Oró, E., Garcia, A., \& Salom, J. (2016). Experimental and numerical analysis of the air management in a data centre in Spain. Energy and Buildings, 553-361.

Pan, Y., Yin, R., \& Huang, Z. (2008). Energy modelling of two office buildings with data center for green building design. Energy and Buildings, 40, 1145-1152. 
Panayiotou, G. P., Bianchi, G., Georgiou, G., Aresti, L., Argyrou, M., Agathokleous, R., . . Chrisodoulides, P. (2017). Preliminary assessment of waste heat potential in major European industries. Energy Procedia 123, 335-345.

Patterson, M. K., Tschudi, W., VanGeet, O., \& Azevedo, D. (2011). Towards the Net-Zero Data Center: Development and Application of an Energy Reuse Metric. ASHRAE Transactions, pp. 10-17.

Peng, C., Wang, L., \& Zhang, X. (2014). DeST-based dynamic simulation and energy efficiency retrofit analysis of commercial buildings in the hot summer/cold winter zone of China: A case in Nanjing. Energy and Buildings, 78, 123-131.

Phan, L., \& Lin, C.-X. (2014). A multi-zone building energy simulation of a data center model with hot and cold aisles. Energy and Buildings, 77, 364-376.

Rahmani, R., Moser, I., \& Seyedmahmoudian, M. (2017). A Complete Model for Modular Simulation of Data Centre Power Load. IEEE Transactions on Automation Science and Engineering, 14.

Rasmussen, N. (n.d.). Guidelines for Specification of Data Center Power Density-White Paper 120. Schneider Electric.

Rezaie, B., \& Rosen, M. A. (2012). District heating and cooling: Review of technology and potential enhancements. Applied Energy, 2-10.

Shehabi, A., Smith, S., Sartor, D., Brown, R., Herrlin, M., Koomey, J., . . Lintner, W. (2016, 06 22). United States Data Center Energy Usage Report. Ernest Orlando Lawrence Berkeley National Laboratory.

The Server Rack FAQ. (2007, Oct 11). Retrieved from https://www.server-racks.com/eia-310.html

Thermal Guidelines for Data Processing Environments (3rd Edition) (2012). American Society of Heating, Refrigerating and Air-Conditioning Engineers, Inc. (ASHRAE). Retrieved from https://app.knovel.com/hotlink/toc/id:kpTGDPEE01/thermal-guidelines-data/thermal-guidelinesdata

Wahlroos, M., P€arssinen, M., Manner, J., \& Syri, S. (2017). Utilizing data center waste heat in district heating e Impacts on energy efficiency and prospects for low-temperature district heating networks. Energy, 1228-1238.

Wahlroos, M., Pärssinen, M., Rinne, S., Syri, S., \& Manner, J. (2018). Future views on waste heat utilization - Case of data centers in Northern Europe. Renewable and Sustainable Energy Reviews, 1749-1764.

Yu, J., Jiang, Y., \& Yan, Y. (2019). A simulation study on heat recovery of data center: A case study in Harbin, China. Renewable Energy, 154-173.

Zimmermann, S., Meijer, I., Tiwari, M. K., Paredes, S., Michel, B., \& Poulikakos, D. (2012). Aquasar: A hot water cooled data center with direct energy reuse. Energy, 237-245. 